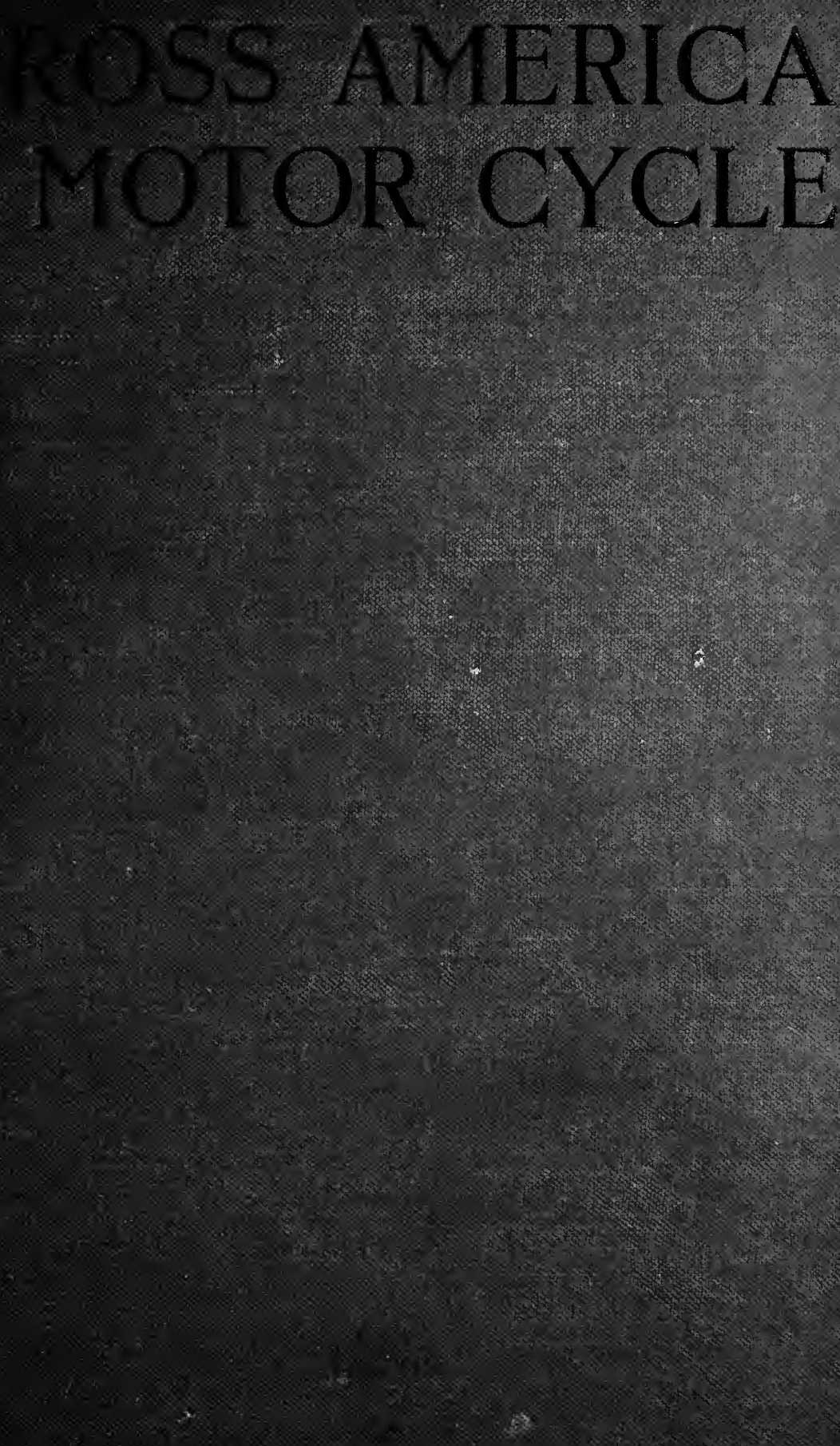

6)

C.LSSHEPHERD 


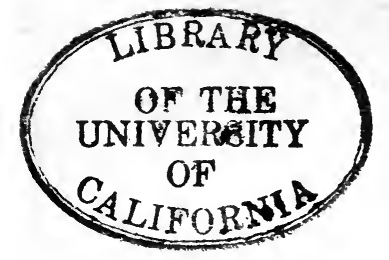




ACROSS AMERICA BY MOTOR-CYCLE 




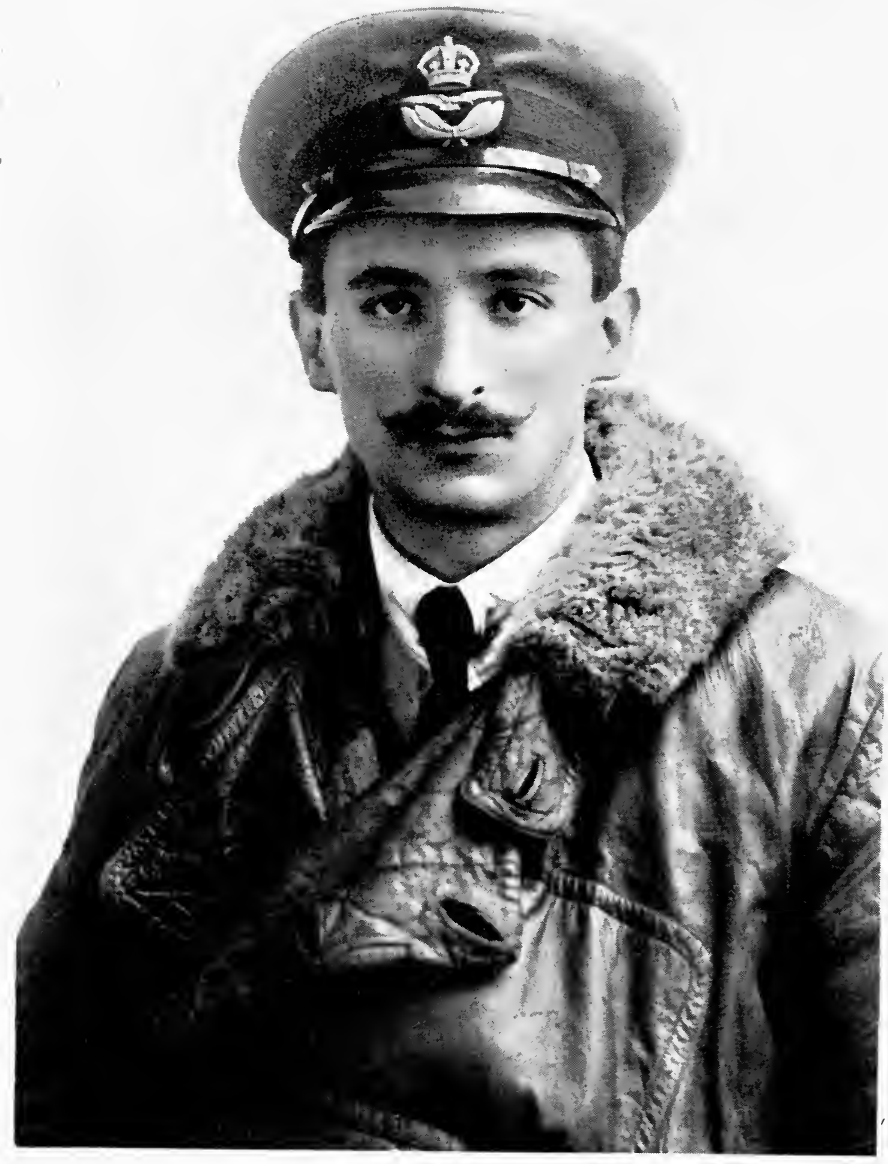

Poktrait of the Author. 


\title{
ACROSS AMERICA BY MOTOR-CYCLE
}

\author{
BY \\ C. K. SHEPHERD
}

ILLUSTRATED

NEW YORK

LONGMANS, GREEN \& CO. LONDON : EDWARD ARNOLD \& CO.

1922

All rights reserved 
Made in Great Britain

by Butler \& Tanner, Frome and London 


\section{E/69

\section{PREFACE}

A few months after the Armistice of 1918 was signed, when the talk of everyone concerned was either wHEN they would be demobilized or what they would do when they WERE demobilized, two young men were exchanging views on this same subject in the heavy atmosphere of a very ordinary hotel somewhere in London.

One was wondering how near, or how far, were the days when he would see the old home-folks once again "way back in Dixieland."

The other was wondering what form of dissipation would be best suited to remove that haunting feeling of unrest, which as a result of three or four years of active service was so common amongst the youth of England at that time.

"How about getting married ?" suggested the one.

Then followed a long pause, wherein the other was evidently considering the pros and cons of such a unique proposition.

"Nothing doing," he replied eventually - " not exciting enough, old man." Another pause-" And when I come to think, I don't know of any girl who'd want to marry me even if I wanted to marry her." And as if to give a final decision to any proposal of that nature, he added-" Besides, I couldn't afford it!"

"But I tell you what I will do, Steve," said he, "I'll go back with you across yon herring-pond and have a trot round America." 
So that was how it happened.

Two or three months later, when I arrived at New York from Canada, I purchased a motor-cycle and set out to cross the continent to the Pacific, and I have it on the best authority that this was the first time an Englishman had ever accomplished the trip on a motorcycle. If it is so, I don't wonder at it !

The whole trip, which covered just fifty miles short of 5,000, was undertaken quite alone, and although spread over about three months, constituted a day or two short of a month's actual riding. For the benefit of brother motor-cyclists who may be interested in such details I may add that I dispensed entirely with the use of goggles from beginning to end, and except at stops in large towns on the way I wore no hat. I think that when the motor-cyclist gets accustomed to doing without these encumbrances he will find the joys of motor-cycling considerably enhanced.

The total number of replacements to the engine alone comprised the following: Five new cylinders; three pistons; five gudgeon pins; three complete sets of bearings; two connecting rods, and eleven sparking plugs.

The machine was entirely overhauled on four occasions between the Atlantic and the Pacific, and on three of these by the recognized agents of the manufacturers. The engine cut-out switch was the only part of the machine that did not break, come loose, or go wrong sooner or later. I was thrown off $\mathbf{1 4 2}$ times, and after that I stopped counting! Apart from that I had no trouble.

Contrary to what the reader may think, I paid considerable care to the machine, particularly in the early stages. For the first three hundred miles I barely exceeded twenty to twenty-five miles per hour in order 
to give the machine a good " running-in " before submitting it to harder work. At the end of the trip I had spent more in repairs and replacements than the original cost of the machine, and I sold it at San Francisco for just over a quarter of the amount I paid for it three months before.

And I am still as keen a motor-cyclist as ever!

The machine was of the four-cylinder, air-cooled type, and I have nothing but praise for the smooth running that this type affords. I have ridden scores of machines at one time and another, but never have I driven any motor-cycle that for luxurious travel could I even compare with the one mentioned in this narrative. As regards reliability, however, I must leave the reader to form his own opinion from the facts, which occurred exactly as I have stated them. Nothing in this book is set down in malice, and I can only hope that my case was exceptional so far as the frequent breakdowns were concerned. I must admit that the conditions were exceptional and that anyone crossing the United States on a motor-cycle might expect trouble sooner or later.

The reader may observe that I say little of tyre trouble throughout the story. That is for two reasons: the first is that there is nothing at all interesting in the narrative of repairing a puncture, for instance; the second is that I had very little trouble indeed to complain of. With the smooth, even torque that is so characteristic of four-cylinder engines, tyre trouble is easily halved, and practically all that one has to fear is the terrible condition of most of the roads. I arrived in San Francisco with the same tyres as I had when I started, and they were still good for several hundreds of miles more.

Petrol consumption, too, was excellent. Those who 
have not known high-powered, four-cylinder motor-cycles would probably think the consumption would be about forty miles to the gallon. On the contrary, I found my machine much more economical than the samepowered V-twin. As far as I know I averaged about 75 m.p.g. " all on."

The journey was comparatively uneventful. I never had to shoot anybody and nobody shot me! In spite of the relative wildness and barrenness of the West, there were always food and petrol available in plenty. I spent most nights at the side of the road and experienced neither rheumatism nor rattlesnakes.

In the following pages I have endeavoured to portray America and Americans exactly as I found them and as they appealed to me. If at times I perchance may give offence to any who are lovers of all and anything American, I do it without intent. Suffice it to say that before I went I had the highest opinion of anything that came from that worthy country, so that it cannot be claimed that I am one of those "Pro-British-everytime" individuals who delight in criticizing other countries and other peoples in order to gratify their own sense of national or other superiority.

Finally, I will ask the reader to be patient, or at any rate, not over-critical when he or she may confess to being bored. For the sake of making this a complete record of my wanderings $I$ have included that which may lack interest, and as I can lay claim to no graceful diction, I may, I am sure, rely on the reader's indulgence towards the narrative of quite an ordinary, unaspiring, British motor-cyclist.

$$
\text { C. K. S. }
$$

Birmingham, 1922. 


\section{CON'TENTS}

PAGE

Prologue.

\section{Traffic in New York}

My Efforts to Become Americanized-Reflections on New York Traffic-Dissertation on American Roads-Coney Island-Equipment for the Journey

\section{New York to Philadelphia}

Companions in Distress - "The Playground of the World "American Proclivities towards the Superlative-A Lapse into Philosophy-Introduction to the "Detour" - The Good Samaritan Rewarded-Philadelphia-Adventures with a Garage Proprietor .

\section{Philadelphia to Washington}

Prosperity in New England Villages-Motor-cycling de LuxePeregrinations of a "Tin Lizzie"-Insights into the Inner Life of an American Highway-Humouring a Negro-Self-conscious Scruples-Illuminated Signs-Hotel Life in Washington . .

\section{Exceeding the Speed Limit}

Experiences of Brick Roads-Approaching the Alleghanies-The Lust for Speed-And Its Consequences-Queer Methods of Enforcing the Law-Stranded . . . . . . .

\section{Across the Alleghanies}

Soliloquies of the Humble Poor-The Subtleties of Advertisement Hoardings-Corn in Egypt-The Peregrinations of an English Sovereign-A Whiff of Good Old London-Appreciation of Nature in America-Lizzie Reports Sick-Lead, kindly Light-Autosuggestion as an Aid to Sleep . . . . .

\section{The Dixie Highway}

I Make the Acquaintance of the Ohio River-Lizzie develops Acute Indigestion-The Irony of Henry Ford-I administer First- 


\section{CONTENTS}

PAGE

aid-Hero-worship to a Rag-and-bone Merchant-A New Use for an Old Treo-The Ubiquitous Columbus-The Friendly TramThe Dixie Highway-Eulogy to the City of Dayton-My Extravagant Taste for Cake-An alfresco Meal-A Final Burst of Extravagance-Home Once More . . . . . .

\section{Cincinnati and Onwards}

Cincinnati-A Memorable Day-Aspersions on an American Repair Shop-Chess-board Roads-The Humour of Decorated Telegraph Poles-Soliloquy on the Pike's Peak Highway-Effects of State Boundary Lines-Indian Corn-A Luxurious BatheIndianapolis-The 3A Club-What Constitutes a Good Road .

\section{INDIANA AND IlLINOIS}

How Dirt Roads are Cultivated-A Brush with a Road-plough - How Flivvers "get through"-A Bad Patch and a Good Samaritan-The Subtleties of General Merchandise-I attract a Crowd in Springfield-Taken for a Movie Actor-Future Cities of Illinois-Illinois River-The Mississippi at Last-I sleep on a Railway Embankment .

\section{Stormy Weather in Missouri}

Hannibal-Infantile Automobilation-Rain in Missouri-I get Annoyed-Railroads v. Highways-Kansas City . . .

\section{Results of a Breakdown}

Kansas City-I visit Lizzio on her Sick-bed-I visit an Editor in his Lair-Kansas City gets My Story . . . .

\section{The Santa Fé Trail}

Westward Again-The Santa Fé Trail-Mosquito Nets-Into the Great Prairies-I sleep in a River-Pio-Prairie Towns-In a Thunderstorm-Colorado Reached-The Map proves not InfallibleA Detour to the Heart of the Rockies-Rain Again . . .

\section{The Royal Gorge of Arkansas}

A Strange Dwelling-I am Taken for an American-Supper in Stylo-Sleep in Style-Breakfast and Lunch in Style-The Sun Once Again-Housebuilding at Speed-An Appreciation-The Rockies-Pueblo-Pike's Peak-The Royal Gorge-The Lust for Taking Pictures-Picturesque Names-The Worst Road in America -A Mud Bath-The End of a Perfect Day . . . .

\section{In Southern Colorado}

Strange Mountain Forms-Trinidad-A Flivver to the RescueThe Raton Pass-A Wonderful View-At the Feet of the Rockies -A Phantom Road-Prairie-dogs-Companions-Lizzie sheds a Sprocket-A Tiring Search-The Biggest Thing in Mud LakesWagonmound-Argument with a Linemaster . . . . 


\section{New Mexico}

Adventures with a Railway-Stuck Once Again-Assistance from California-House-hunting by Caravan-Las Vegas-A Wonderful Ford-A Mexican Village-Lizzie Clean Again-The Travelling Tinsmith-Santa Fé at Last . . . . .

XV. Santa FE

Santa Fó-Adobe Architecture-The Art Museum-Where Americans Hustle Not-In the Limelight Again . . .

\section{The Rio Grande Valley}

Departure from Santa Fé-La Bajada Hill-Albuquerque-The Rio Grande-Indians-The Morals of Mountains-Socorro-Camping in the Mountains: A Farmyard Episode . . . .

\section{The Petrified Forest of Arizona}

Magdalena-A Strange Metamorphosis-I Sport a Camp FireA Strange Sight-The Petrified Forest of Arizona-Holbrook-Lost in the Arizona Desert-Mosquitoes Again-Winslow-An Ingenious Anti-speeding Stunt-That Cylinder Again !-A New Use for Old Sign-posts-Meteor Mountain-The San Francisco Peaks-Fairyland-Flagstaff .

\section{The Grand Canyon}

The Lowell Observatory-Wonders of Mars Hill-Ptomaine Poisoning-Flagstaff Dwellings-Towards the Grand Canyon-A Wonderful Ride-The First Approach of Loneliness-The End of the World-The Greatest of all Natural Wonders

XIX. The Mohave Desert

Lizzie Comes to Grief-Etiquette of the Road-The Tragedy of Peach Springs-Kingman-Desert Vegetation-Yucca-The Art of Rut-riding-The Tomb of a Town-The Colorado Needles-A Marvellous View-Oiled Roads-Ludlow .

\section{I Reach the Pacific Coast}

Comrades in Arms-Lizzie begins to Complain-Death ValleyAn Unfortunate Caravan-The End of the Desert-The Cajon Pass-Los Angeles is Startled . . . . . .

\section{Los Angeles to San Francisco}

Los Angeles-Friendly California-Towards 'Frisco by NightI Dream a Dream-The Californian Missions-The Salinas Valley-The Last Sleep-Lizzie gives it up Again-The Struggle for 'Frisco-4,950 at last! . 


\section{LIST OF ILLUSTRATIONS}

TO FACE

PAGE

Portrait of the Author . . . Frontispiece

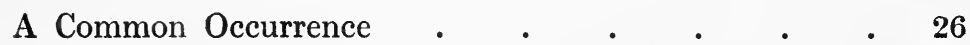

An Awkward Stretch of Road in Indiana . . . 74

The Midnight Couch . . . . . . . 74

The Oldest House in America, at Santa Fé $\quad$. 150

The Art Museum at Santa Fé . . . . 150

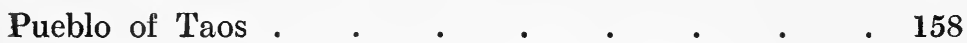

The Rio Grande, New Mexico • • • • • 162

A Petrified Leviathan $\quad . \quad$. $\quad . \quad$. $\quad$. 170

Lizzie in the Petrified Forest, Arizona . . . I70

The Trail to the Grand Canyon . • • 178

The Lowell Observatory, Flagstaff • • • 178

San Francisco Peaks from Flagstaff . • . 178

The Bottom of the Grand Canyon . $\quad$ • $\quad$ - 188

Cactus Trees near San Bernardino • • • . 206

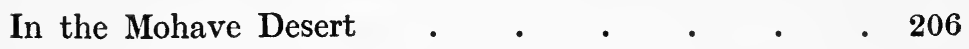




\section{PROLOGUE}

One bright morning in June-to be exact, the thirteenth (the significance of that number will be apparent later), in the year of Our Lord 1919 and in the year of American Prohibition 1, a small assembly of mechanics, passers-by, and urchins witnessed my departure from a well-known Motor Cycle Agency in New York.

The machine, a perfectly new and very powerful motorcycle, was dazzling in her pristine beauty. No spot or blemish could be seen on her enamel of khaki hue. No ungainly scratch or speck of rust marred her virgin form. Her four little cylinders, gaily murmuring as the engine joyfully sprang into life, seemed to hide a world of romance as if they were whispering to each other of the days that were to come, the adventures and experiences they were to encounter, and the strange lands they were to see. The purr of her exhaust, healthy though muffled, smooth and even in its rhythm, was music in my ears. A thing of beauty is a joy for ever, and to those who know the call of the open road and who love to feel the rush of the wind and the glamour of speed, such was this machine. Although she was in reality but an organized combination of various pieces of unfeeling, soulless metal, without even a name, and known only by a sordid number embossed on a tinplate provided by the Law, she was soon to develop a character and personality of her own. She was to play the rôle of sole companion in the weeks and months to follow. There would be times when I should 
curse her profanely and at the same time love her passionately. I pictured vast prairies and deserts where we should be alone together, far from the haunts of man or animal or perhaps of any living thing-times when it would depend upon HER to bear me on to civilization. So I trust, reader, that you will not think I was waxing too sentimental on that memorable day in June.

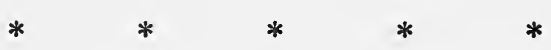

The mileage indicator just flicked to 4,422 .

I was hungry, hungry as a dog. I was thirsty too, and tired-oh, so tired! The skin on my face was tanned dark with the desert sun and bore the dirt of many days' accumulation. The growth of the previous week was upon my chin. My hair was bleached and dishevelled, my clothes and boots laden with the sand and dust of Arizona and California. With a bandaged, broken finger, and the rest skin-cracked and bloodstained with the alkali sand, I held the handles with the palms of my hands. The sole was missing altogether from my right boot, and the left contained many a piece of stone or gravel from far away. A couple of empty water-bags flapped up and down on the handlebar, and as the old bus dragged her weary way on three cylinders through the crowded streets of Los Angeles her hideous clatter told many a tale of woe. I decided at that moment that the best thing in all the world was to get something to eat and drink.

"What's the day of the month ?" I asked, when with a final "clank" of the engine we drove into the Agency Garage.

"The seventh."

"The month?"

"August." 
"And what's the year?"

"Nineteen nineteen."

"The seventh of August nineteen nineteen," I mused, and relapsed into contemplative silence. . . .

Some one spotted the registration plate "N.Y.8844" and "rumbled" that I had come from New York.

"When did you start?" they asked in curious tones. The question pulled me up with a jerk and brought me back to normal existence, so inadequately measured by time.

"Oh, seems like ten years ago!" I replied, and relapsed once more into reverie. 



\section{CHAPTER I}

\section{TRAFFIC IN NEW YORK}

I spent the better part of two days in the survey of New York City from all points of view. In the Pullman from Niagara I had decided that America would probably be just as bad as any European country for robbing the alien. I would therefore simulate the gentle habits and customs of these (hitherto) worthy people. Having some slight knowledge of their language I would endeavour to acquire perfection in the art of American self-expression. I would cultivate the correct pose of the hat and wear boots with knobbly toes. Only a little practice would be required before I should be able to gyrate a cigar at the accepted velocity from one corner of my mouth to the other. In a little while, methought, I should feel much more at ease in tight-fitting clothes with ridiculously small sleeves and three inches of projecting shirt-cuffs. Maybe I should improve my outlook on the world if I viewed it through a pair of large, round, ebony-rimmed spectacles. There was just a possibility that I should some day appreciate the soothing charm of a muchoverworked morsel of chewing-gum. With all these splendid accomplishments I could no doubt dispense with the less attractive habits of Modern America.

Let me say at the outset that I proved a dismal failure. I would sooner master the Chinese than the American lingo. The infinite variations of nasal accomplishment 
outnumber by far the tribal dialects of India and leave the poor student to wonder and despair. Why! the number of orthodox ways of translating the plain English word "Yes" is probably beyond the scope of mathematical deduction! The shades and blends between "Yep" and "Ye-oh" alone are sufficient to put a spectrograph of the sun to shame.

For four months I travelled through the wilds of New York, Ohio, and Illinois, and even into the civilized states of Colorado, New Mexico, and Arizona, in a vain search for the man who pronounced "Yes" with a final "s." In the end I found him, lurking in a little restaurant in Los Angeles. I gazed in wonderment intense and rapturous when I heard it. I have his pedigree. He said he came from Boston. Boston, according to all well-informed Bostonians, represents the acme of perfection in all things relating to education, etiquette, and propriety. As such it is unassailable by any other city in America.

There was a time early on when I thought I was succeeding well. I found that I did better by dispensing with speech altogether. If I dressed in a "Palm Beach" suit, walked on people's feet, elbowed my way through passers-by, and continually repeated to myself " The earth is mine and all that therein is," there was never any doubt but that I was a "Native Son."

It is superfluous for me to say, however, that after many trials and more rebuffs, I ultimately abandoned the idea of becoming Americanized. "After all," thought I, "what sane Englishman wants to be an American ?" The project had been but a brain-wave to combat the "H.C. of L." To the uninitiated, that is the recognized "Hearst" abbreviation for the "High Cost of Living," a topic which so frequently appears in American news- 
papers that editors were forced to face the question of either referring to it in symbols or of cutting out the "Want-Ads." Finally, therefore, I consoled myself that it was better for hotel bills, cinemas, ice-cream sodas, petrol, and other necessities to rise 200 per cent. on my approach than for me to lose my own soul. Incidentally, virtue does not always have its own reward. On my return to England I heard many accusations against me. "What an awful American accent you have!" was the greeting of many one-time friends.

... Some have recovered. Others are still in hospital!

* $*$ * $\quad * \quad * \quad * \quad *$

It took me some time to get accustomed to the traffic of New York-rather should I say, to its habits and practices. New York itself consists of a network of streets and avenues ingeniously arranged on an island which is about five or six times longer than it is broad. The avenues run the length of the island and the streets run at right angles across them. In addition, "Broadway" wobbles across from one end of the island to the other, cutting the avenues at a weird angle of anything between nothing and twenty degrees.

At all the important street crossings was stationed a "traffic cop" whose duty was apparently to hold up at the most inconvenient intervals all the traffic going one way until all the traffic going the other way had passed. Then he blew his whistle and Hey, presto! the traffic in the other street began to move. It was fatal to move before the whistle was blown. I didn't know that!

I had been sailing down Sixth Avenue, just trying the machine for the first time, as a matter of fact. Every- 
thing went smoothly. I felt at peace with all the world. Here was I on my iron steed of ten little horses, about to begin a long holiday wherein I should forget the Kaiser and his deeds and the four or more years of my existence that had gone in helping to bring about his everlasting undoing. But all of a sudden :

"Why the jooce don't yer stop, yer Goldarn young son of a gun?" bellowed an irate "cop" who gesticulated but a few feet from my front wheel.

"Well, why the blankety blank should I blankety well stop, anyway?" I returned, not to be outdone, as I pulled up in the exact centre of 34th Street, Sixth Avenue, and Broadway.

I could see a crowd beginning to collect. I don't like crowds at any time. I have a keen antipathy for publicity . My friend the " cop" drew nigh. "See here, young fellar: whar yer from?" he inquired, evidently anxious to investigate further the mental condition of this unique defier of the Law. . . . To cut a long story short, I was finally constrained by good judgment to avoid further constabulary hostilities and, in accordance with the somewhat over-ardent desire of the "cop," retired like a whipped schoolboy to the corner where there was already a long queue of waiting automobiles and taxis. In a few seconds the whistle was blown and the procession sailed across 34th Street, headed by a much-humbled motor-cyclist.

I should explain at this juncture that a motor-cyclist is an altogether despised individual in America. Motorcycles are not popular over there. With few exceptions they are owned by delivery men, newspaper boys, "traffic-cops" and sundry other undesirables. Personally I do not wonder at it. The roads and streets in the 
cities are bad enough to ruin the constitution of any but the most confirmed young "blood" who does not mind risking a few broken bones. I have seen places in Broadway where the tram-lines wander six or seven inches above the surface of the road and where the pot-holes would accommodate comfortably quite a family of dead dogs within their depths.

So much for the cities. The roads that traverse the country are with few exceptions nothing better than our fifth-rate country roads on which no self-respecting Englishman would ride.

Here and there, in the far East and the far West, are found stretches of concrete or macadam. Somehow, the Americans think they are great road-builders. A couple of inches of concrete laid over a garden-path or a sheeptrack, with the cracks filled in with tar, represents the zenith of road construction in this country of ninety odd million inhabitants. I should like to see some of those concrete roads when they have had a few years' solid wear with heavy lorries and occasional traction engines.

Ninety-five per cent or more, however, of America's highways are dirt roads, or what they are pleased to call "Natural Gravel." In many cases they comprise merely a much worn trail, and as often as not a pair of ruts worn in the prairie. Very often, instead of being a single pair of ruts, there are five or six or perhaps ten, where individual cars have manifested their own personality. When this multiplicity of ruts crosses and re-crosses in a desperate attempt to achieve the survival of the fittest, the resultant effect on the poor motor-cyclist is somewhat disconcerting. But of this more anon. Suffice it to say that on the whole journey of 4,500 miles from one coast to the other, I only saw Four other motor-cyclists on the road anywhere. 
So the reader will perhaps understand why the poor human who travels in this fashion is to be pitied, and why his associates in the towns and cities are desplsed by the rest of the community.

When I had acclimatized myself to the traffic of New York and could worm my way successfully in and out of the " hold-ups" or dart between trams, taxis, cars, and other impedimenta without danger either to the community or to myself, I felt that it was time for me to commence my peregrinations in earnest.

I decided first, however, to visit Coney Island, which is within easy reach of New York (it is only a few miles away), and, with a plentiful supply of trains, trams, and 'buses, is fed with a never-ending stream of pleasure-seeking humanity. It has one avenue of perhaps a couple of miles' length running parallel with the beach, and every nook and corner on both sides accommodates a "fun palace" of some kind. There are dancing-halls by the dozen $;$ mountain railways, switchbacks, and roundabouts by the score; soda fountains by the hundred. Fronting the beach are hotels, boarding-houses, and restaurants of all types save the best. Coney Island is decidedly not a place for the élite. Hither flock young couples, married or single, representatives of the American democracy, for a week-end of frivolity. The beach is at all times sprinkled, as by a human pepper-box, with specimens of the " genus anthropomorpha" of all sizes, of all ages, of all shapes, and in all stages of dress and undress. I opined that indeed 'twas no place for me, and with one push of the starting pedal the motor was a living thing. "Enough is as good as a feast," and an hour at the Playground of New York was an hour well spent; but I left it for ever behind me without the slightest desire or 
intention of ever returning to its whirl of plebeian gaiety.

Arrived once more at New York City, I prepared to make my adieux. I had two handbags only, one a beautiful new dressing-case, resplendent with pig-skin writing pads, ebony brushes, and glass bottles, and the other, a slightly larger one, which accommodated my spare clothing, boots, etc., and the miscellaneous collection of junk that every globe-trotter inevitably carries around with him.

Now I have an inherent contempt for side-cars, although had one been available at New York when I bought the machine I should have taken it and carried all my luggage with me. That would have been the acme of luxury. As it was, however, I contented myself with a good strong carrier and with many straps; the dressing-case, surrounded by a good thick blanket, was securely attached to the back of the machine,. The other bag I " shipped" on by train to my predetermined stops across the country.

That dressing-case must have weighed fifty or sixty pounds, and with the blanket around it looked an alarming size when in situ. There was no hope for it. I'm that kind of individual who always likes plenty of silk shirts and pyjamas and things, so it didn't occasion me the slightest worry if the people did stare wildly at me as I passed through their towns and villages. And they "sure" did! 


\section{CHAPTER II}

\section{NEW YORK TO PHILADELPHIA}

"Gotter match ?" he inquired as I pulled up near him.

I had left my palatial sky-scraper hotel only fifteen minutes before. Soon, I contemplated, my experiences in and around New York would be past history. Happy and light-hearted, I was humming along that boulevard with the truly wonderful surface which runs along the edge of Manhattan Island. It is known as "Riverside Drive," and here dwell many of America's millionaires. A young fellow and his companion with a Harley-Davidson and side-car at the side of the road attracted my attention. Neither of them looked as though he were a resident of that district. A khaki-coloured shirt, thick corduroy breeches, leggings, and boots were their only attire. One of them held up his hand when he saw me.

"Maybe these fellows know something about the roads," thought I; so I stopped.

To stop a motor-cyclist and ask him for a match seemed quite a unique departure from the well-established English customs with which I was familiar. Feeling benevolent, I silently proffered a box of "England's Glory". wax vestas. Without a word he took one, scrutinized it closely as though it were something wonderful in the art of match-manufacture, and slowly lit his pipe. A dozen puffs ensued. He broke the silence.

"Where you from?" 
"When I left it they called it 'England," ' I replied.

Another dozen puffs.

"Where you goin'?"

"I may get to San Francisco some day."

"You sure got some bit of pavement in front of you. I said it."

"Well, I guess it's never so bad but what it might be worse," I hinted.

He spat twice, puffed a few clouds, spat again; took another look at me, then glanced at my machine.

"You got some bird there," he ventured, and then added, as if to place the assertion beyond all doubt, "I said it."

I agreed that it ought to be able to get along.

"Yew said it.-See that bird thar ?" he asked, pointing to his machine. "Waal, I guess she can move some too; she done eight thousand miles on them roads, an' I guess they warn't mos'ly booleyvards neither."

In the conversation which followed, mainly in reference to many inquiries on my part as to the various "National Highways" which I had learnt were occasionally to be found throughout the country, I gleaned from this worthy native son that it would be better for me to "go back 'ome and pick strawberries" than to continue farther with such an obviously insane desire as to cross the American Continent. I persisted, however, that having come thus far, I would at any rate continue while sanity remained, although I should certainly bear his good advice in mind for future reference.

With a final injunction from him that I should know him when next I saw him if I were fortunate enough to subsist in the land of the living, we parted, and after a trip on the Ferry across the Jersey River, I was soon 
winding my way out of the drab and dreary suburbs of Newark.

It would be ineorrect to say that the best people do not go to Atlantic City. Americans, I believe, reckon this well-known seaside resort to be one of the nine wonders of the world. No free-born American citizen, I do not doubt, would give the credit of the other eight, whatever they may be, to any foreign country. On this assumption I felt I should have no difficulty in identifying the other eight when I had seen more of "God's Own Country."

Now Atlantic City is just one hundred per cent. American. It would be impossible to associate it with any other country but America. To begin with, it has the inevitable " million-dollar" pier. Let me explain that nothing in America is worthy of popular patronage unless it costs at least a million dollars. When I was at Niagara I was told how many million gallons of water flowed over the falls in a year. No one (on the American side) seemed to worry very much about the magnificence of the falls or the grandeur of the river. Such sordid interests do not appeal to them. But ask someone how many million horse-power will be developed in a year, and see with what eagerness he relieves you of your ignorance! The American public wILL have millions in their calculations and their lust for the superlative must be appeased.

In Atlantic City there are naturally many objects of interest to the budding student of modern life like myself, but, on the whole, the amusements of this nation do not differ considerably from the modest efforts of our own. There one can see the usual bashful maidens whose main delight is to recline on the sand or parade the beach in the latest thing in bathing costumes,-but never under any circumstances to get them wet. Also we find 
the usual stores where every conceivable variety of picture post card or "present from ... ." can be bought.

In two hours I was aweary of Atlantic City. In a very superior frame of mind I trod on my feelings and the kickstarter of "Khaki Lizz" (my soubriquet for the machine, which was finished entirely in that delightfully-reminiscent hue) and turned her nose towards the west. Philadelphia, I decided, was to be my resting-place that night.

To be hot on the scent of Philadelphia was one thing; but to get there was quite another. A glorious threemile stretch of macadamized road out of Atlantic City was indeed a tempting bait, and I admit for a few luscious but brief moments I set at defiance all limits of speed imposed for the general welfare of the public by worthy law-makers upon the motoring population of New York State. I have always contended (privately, not in public !) that laws are only made to be broken. I might perhaps add that I was destined afterwards to supplement this somewhat outrageous dictum with a further- " He only is entitled to break laws who thoroughly knows and understands them!"

As every wanderer in this vale of tears discovers, all good things come to an end some time. That three-mile stretch of macadamized road very soon came to an end. It ended, as far as I remember, in an abrupt right-angle corner where in an endeavour to get round at about forty-five miles an hour I nearly met myself coming back, and from that point the road gradually bore resemblance to an elongated dust-heap. They call it " natural gravel," which means that in the opinion of the road engineers of that time the natural surface of the road did not need any reinforcement in the way of metal. I should imagine that about 99 per cent. of all the roads in America are of 
this construction, the remaining 1 per cent. being either covered with a layer of concrete, or macadam, as in any civilized European country. At times, very few and far between, this natural gravel forms quite a tolerable surface where there is not much traffic, but it must be remembered that motor-cars are used in the States on a far greater scale than is ever dreamt of in England. I was, in fact, simply amazed at the tremendous number of cars in the various towns and villages through which I passed. I have sometimes been in a town, and quite a large one too, where it was almost impossible to find a place at the side of the pavement where $I$ could leave my machine. Every available space was taken up with a car, and in some towns, Salt Lake City for instance, I have seen cars " parked" along the side of the road twodeep, so that to cross from one side of the road to the other one has to traverse four separate ranges of automobiles. In the summer, thousands of cars are travelling all day long between Atlantic City and the adjacent large cities, so that the reader can perhaps imagine the state of all the main highways in that direction.

I was here introduced to a diversion which at first seemed quite an interesting one, but which continued familiarity certainly turned to contempt. I refer to the "detour." The unfortunate motorist is perhaps ploughing his way steadily along through the gravel, dust, and sand. He encounters a barrier across the road bearing a notice that repairs are going on and that he must follow the detour indicated. The road selected, I believe, is generally the one with the most pot-holes, ruts, mountains, canyons, etc., in its formation in the surrounding district. Sometimes in these detours one finds further auxiliary detours until finally one has to use the utmost intelligence 
and a compass in order to get back to the main highway.

I did not, therefore, arrive in Philadelphia strictly to schedule. I was many times tempted to take up my abode at a convenient spot on the side of the road. Several times I dismounted and examined a promising spot, but always there was some very serious objection. This objection either took the form of frogs or of mosquitoes or of both. As we used to read in the days of the War, "the enemy was present in large numbers." I did not relish either the prospect of being kept awake indefinitely with the objectionable gurgling of a battalion of bullfrogs or of being eaten to death in my slumbers by a nation of bloodthirsty mosquitoes.

So I spun onwards, ever onwards towards Philadelphia. Meanwhile the sun was sinking lower and lower in the west. The nearer I got to Philadelphia the more numerous became the cars on the road. It seemed as though the whole of Philadelphia frivolled at Atlantic City on a Sunday afternoon. I was working my way along, dodging tremendous pot-holes and ruts, imagining myself in an hour or two's time reposing comfortably between clean white sheets. All of a sudden a most distressing noise came across my ear. It appeared to be a motor-cycle in pain. At times there was only one cylinder firing. Sometimes there were two. At other times there was none at all. I drew in to the side of the road and waited for the unfortunate author of this disturbance to arrive.

He soon emerged from the darkness. He had no lights, and was only too pleased to stop at the sight of another motor-cyclist.

"Why, I thought I was the only madman about here," I greeted him, surprised but gratified to know that there 
really were other seemingly sane people who rode motorcycles in America.

How delighted he was to meet another Englishman! He had, he explained, been in America only a year or two, having come from my old home town of Birmingham during the War. He had got so "fed up " with Americans that it was a treat to set eyes on anyone from the Old Country.

He was a youth of eighteen or nineteen years, and after I had fixed him up with a couple of sparking plugs and attended to a few other urgent requirements, he asked me abruptly, but quite politely, the inevitable question, just as I might have expected. "Where you from, an' where you goin'?"

I explained that I was making for Philadelphia, where I hoped to find somewhere to lay my weary head.

"Well, if you don't want anything very luxurious," said he, "I think I can fix you up all right, if you don't mind going on ahead to light the way."

I gladly assented, and by this means, with my brilliant headlight illuminating the road, it did not take us long to reach the Delaware River, on the opposite bank of which stood the fine old city of Philadelphia. It took a quarter of an hour to cross the river by the ferry, but once in Philadelphia my friend was happy. "Now you follow me," he said.

He had no lights whatever, but his engine was running well, so I agreed and followed. This was not in itself very easy. I am perfectly certain that I have never seen ANY motor-cycle ANYwHERE dash along at such a rate through a city. Although it was dark and I could not see my speedometer, I am sure that he must have travelled about forty-five miles per hour through the 
streets of Philadelphia. They were certainly good and straight and wide. There was a little traffic here and there, but this did not seem to worry our friend in the slightest. Occasionally we saw a "cop". or two standing on a street corner make a half-hearted attempt to step into the road to hold us up. Our friend, however, was desperate and would stop for no one. After about a quarter of an hour's riding, dodging round corners and shooting past obstructions at a tremendous pace, he pulled up at a small corner house in a secluded portion of the town and we dismounted. He lived with his mother, he explained, but she was away in New York. Also he had lost his latchkey. Also it was really a florist's shop, but he was sure I wouldn't mind. "There is nothing for it," he said, "but to climb the fire escape and get in through the front window."

I shouldered him up to an iron frame projecting from the house. Thence he clambered on to a rickety fire escape leading up the wall into blackness, and he was soon lost to sight. A few moments later the front door opened and we pushed our muddy, dirty machines on to the clean linoleum of the front room, where they remained overnight surrounded by pots of roses, carnations, palms, and ferns. This, he explained, was quite the usual procedure and his mother would not mind a bit!

It was then about 11.30, and when we had washed some of the dirt from our faces we sallied forth in quest of a meal. We had no difficulty in picking up the scent of a flourishing cafeteria. Neither did we have any difficulty in disposing of disgusting quantities of hot coffee and "waffles," a commodity peculiar to America, resembling pancakes and eaten with jugfuls of maple syrup.

Well after midnight we returned to our domicile, and I 
laid me down to sleep the sleep of the righteous. At seven o'clock in the morning I bade farewell to mine host. Not a cent would he accept in payment for my night's lodgings. So, with the parting assurance that he would drop in and see me when he was next in England, we each took our several roads-he in the direction of a neighbouring works where he was employed as a mechanic, and I towards Washington, drifting meekly along the streets at certainly nothing like the speed of the night before.

The road for some distance was good, the sun came out, and the day promised to turn out fine and hot. I soon began to feel an inward content. Everything was going smoothly. I was expecting some money to be waiting for me at Washington, and then I should have nothing to worry about for a long time to come.

As it usually happens when one begins to pat oneself on the back, I immediately had a puncture. It was of course in the back wheel. Meanwhile the sun was rising higher and higher, and when, after about half an hour, I had repaired the wheel, I was feeling very thirsty. Another five miles further on I had another puncture. This time it happened to be exactly outside a garage.

I have known places in England where a certain amount of trade is always guaranteed by the ingenuity of some of the garage proprietors who regularly and systematically throw tacks and nails along the road in their vicinity. It occurred to me that this was a practice not confined to England, as examination revealed the cause of the puncture to be a nice long nail driven through from one side of the tube to the other. Not feeling of a very arduous disposition at the time, I wheeled it into the garage to be repaired.

I am afraid I was rather annoyed at the result. In 
the first place, I had to supply the mechanic with solution. In the second place, I had to take off the tyre for him. In the third place, I supplied a patch; and in the fourth place, I actually had to do the job for him. After settling his account, I finally explained in language as polite as I could muster that in my opinion the practice of strewing discarded nails and other implements on the highway, while not being exactly meritorious in itself, was just as commendable a method of obtaining a business connection as many that were frequently resorted to in other trades or professions of a higher standing. I explained, however, that after having been so successfully victimized by such an artifice, one would consider oneself justified in expecting a much higher standard of workmanship than was apparently forthcoming in his establishment.

Then we parted, the mechanic expressing the hope that he would never (crimson) well see me again, and that if I ever did happen to be coming back that way and got a nail in my (unspeakable) tyre that he would see me in (Arizona) before he would (smoking) well repair it for me! 


\section{CHAPTER III}

\section{PHILADELPHIA TO WASHINGTON}

The scenery now began to look charming. Rolling ranges of hills extending into the distance clustered around as we drew nearer to the Chesapeake River, which flows into the well-known bay to which it gives its name.

"All aboard for Chesapeake Bay."

... I hummed the air to myself as the road abruptly ended and a suspension bridge continued the course across the broad, peaceful mouth of the river. The whole country around seemed to be permeated with a comfortable, wholesome vigour. Nothing seemed shabby, discontented, or poverty-stricken. I passed through many small towns and embryo cities. All were prosperous and all extended a hearty welcome to the traveller or visitor. Stretched across the road between two poles, just before I entered one little town, was a huge white banner bearing the words :-

\section{" CONWAY CITY WELCOMES YOU. WE LIKE TRAVELLERS TO VISIT US. HAVE A GOOD LOOK AT OUR CITY."}

Conway " City" did not prove to be exactly a metropolis. It was probably nothing more than a well-to-do farm town. But the houses were clean and neat, indeed some of them were very beautiful, perfectly up-to-date but never objectionably modern. The roads were a bit bumpy in 
places but not at all bad as American roads go. As I passed out of the town I saw another notice similar to the first :-

\section{"THANK YOU FOR COMING. WE HOPE YOU LIKE US. \\ COME AGAIN."}

I got so used to being welcomed to every town I came to that I forgot I was a "stranger" in a "foreign land." There was not a town or village that did not publish its welcome in some form or other. In the main it was by advertisements. But if $I$ stopped at a wayside store to quench my thirst (oh, the sun was hot !) I was met neither with scowls nor incivility. I am reminded of the old joke of Punch many years ago :-

"Oo's that bloke over theer, Bill ?"

"Dunno; stranger, I think."

" "Eave 'arf a brick at 'im."

That is typical of what we English think of strangers. The man of better education or more refinement perhaps expresses himself differently, but he feels just the same as a rule.

At this juncture in my reveries the macadam road stopped and gave way to "natural gravel." That was quite sufficient to postpone any soliloquies I may have been indulging in until a later date. The entire sixty seconds in every minute were employed in keeping myself substantially upright. Small pot-holes gave place to larger ones, and they in turn to larger still. The loose sand, which was an inch or two deep at the start, soon assumed more considerable depths. As the detective books of our youth used to say, "The plot grew thicker and thicker." I was floundering about from right to left, prodding 
energetically on the ground each side with my feet to maintain some kind of balance. At times the back wheel churned up the sand aimlessly in an endeavour to get a grip on something solid. Here and there the sand and gravel were heaped into great ridges as if a mighty plough had been along that way. Getting through this stuff, thought I, was no joke. Furthermore, it was warm work ; very warm work. Now and then $I$ would find myself directed absolutely without control from one side of the road to the other, and only with the greatest strain could I keep the machine on its wheels. And with all this the "highway" still maintained its regulation width of 90 feet! The casual observer from an aeroplane above would in all probability be attracted by its straightness, its whiteness, and its apparent uniformity. "What a splendid road !" he would think.

Not so I. I was on the point of physical exhaustion with the seemingly-endless paddling and pushing and heaving (and don't forget the half-hundred-weight bag on my back !) when I was thrown on to a steeply-cambered part of the road at the side. The back wheel just slid limply sideways down the slope and left everything reposing peacefully in the natural gravel of Maryland.

When I had extricated myself from under the machine, I surveyed the position with a critical eye. What a road for a civilized country! These Yanks must be jolly-well mad to tolerate such roads as this!

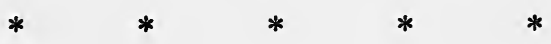

Just then an old Ford came by. It was shorn entirely of mudguards, running boards, and other impedimenta. As he wallowed past me, swaying to this side and that, sometimes pointing at right angles to the way he was 
going and with his old engine buzzing away in bottom gear and clouds of steam issuing from his radiator (it had no cap; it must have blown off !) the driver seemed perfectly at ease. He rolled a cigar stump from one corner of his mouth to the other and gazed nonchalantly ahead. I don't think he even noticed me and my recumbent motor-cycle. I could not repress a grin as his old box of tricks disappeared slowly up the road, wagging its tail this way and that and narrowly averting a catastrophe at every few yards. "You ragtime bunch of tin merchants!" I mused (not so much in reference to the driver as to the nation in general !) as his diminishing form finally side-slipped into the ditch at a bend in the road.

And then a distressing thought struck me: "They'll never believe me when I get back home and tell them !" So I took my little camera out of the tool-box on the top tube and snapped the worst bit of road there and then. A five minutes' struggle followed, in which " Khaki Lizz" was withdrawn from her ditch.

By way of nourishment to sustain me in any further fights with the road, I slowly and meditatively consumed one only orange before proceeding once more.

But things did not improve. Here and there, where the ridges of soil and gravel had not been disturbed, grew tufts of grass and weeds. Huge ruts, crossing and recrossing in the remaining sand, showed where cars were wont to pass as fancy dictated, and with only two wheels it was barely possible to maintain any progress at all.

"Hang it all! This is roo much!" I exclaimed, after a few more precipitate dismounts,-and took another photo and ate another orange.

A mile or two farther on I came to a weird-looking machine at the side of the road. It was a sort of combina- 
tion of steam tractor and automatic plough, but very much bigger and more complicated. Its main function was to chop down en masse the sides and banks of the road and shovel the debris into the middle. Grass, shrubs, bushes, and young trees alike fell victims to its activities. Now this really was the limit! Not satisfied with the condition of the road as it was, they sent forth this "Heath Robinson" mechanism to improve it. I stopped and left the bike standing in the road where it was-there was no need to prop it up against anythingand went back to question the driver of this implement as to its function in life.

He was not perturbed in the slightest either at my question or at the heated state of mind and body in which I approached him. Punctuated by intervals in which he slowly masticated a worn-out chunk of chewing-gum, he explained that all good motorists liked wide roads; that the State Council had decided that motorists should have wide roads ; that they had provided machines for widening roads that at present were not up to standard width; and finally that he was there to see that this machine did Its work properly!

So I took another photograph, ate another orange, kicked the self-starter once more, and pushed on again. The road got worse and worse. Sometimes there were ruts and sometimes there were strips of unploughed field in the middle of it. But I spent no more films on it. The people at home, I decided, would have to take my word for it after all. About ten miles farther on I came to a cross-road. It was perfectly straight and beautifully paved with concrete and stretched from one horizon to the other. With what joy I gazed upon its countenance! There was a wooden shack on one corner, evidently a 


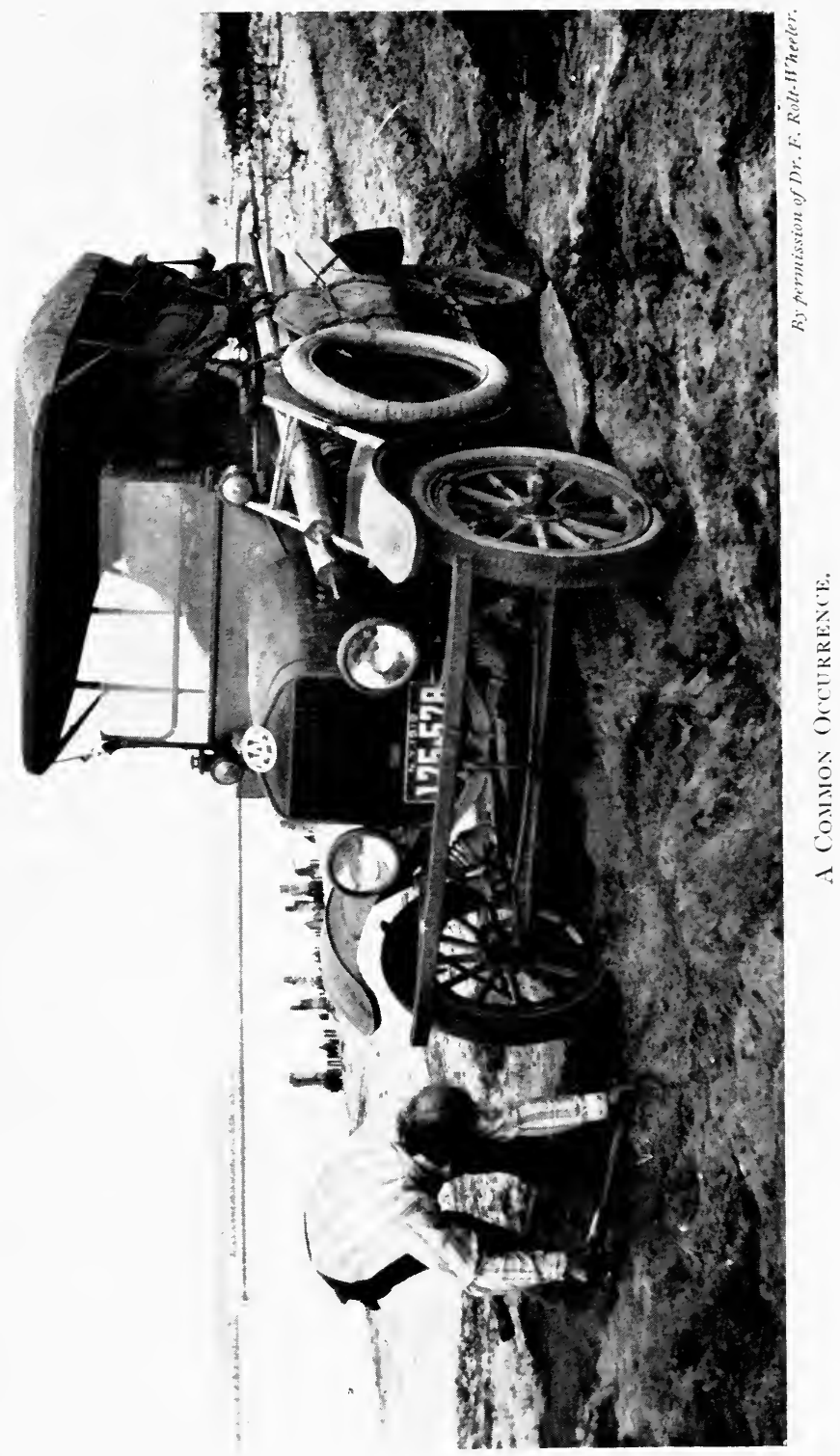



saloon. A negro sat on the doorstep, gazing indolently at me.

"Is this the road to Baltimore ?" I inquired, indicating the concrete highway.

No reply. But he continued to gaze at me, and spat twice.

"Must be deaf," thought I. "How's this for Washington?" I shouted.

Still no reply.

"Say, brother, which is the road to Baltimore?" I inquired as politely as convenient.

The appellation "brother" had its effect. The negro jerked his thumb over his shoulder, indicating that I was to go straight on (and incidentally follow that excruciating stretch of natural gravel).

Fortunately, Baltimore was not many miles away, and when I got there I breathed many sighs of relief. There were paved roads, good and true; macadam and concrete for miles and miles, all the way to Washington. I picked my way by instinct through Baltimore, the capital of the State of Maryland, not stopping for food or rest. I would reach my destination before I gave way to such physical necessities. I certainly had an appetite, but I always feel that more than two meals a day when on tour are not only unnecessary, but mean a dead loss of time, money, and distance.

The reports on the state of the road ahead turned out to be true in every detail, and throwing to the winds all respect for such trivialities as speed limits, I made up for at least a good fraction of the time wasted on the road.

When, about 5 p.m., I pulled Lizzie on to her stand outside one of Washington's " cafeterias," I began to feel an incipient timidity. I doubted whether I should be 
able to get into any respectable hotel. I was covered in dust, and dirt. Headgear of any kind I had dispensed with altogether. My hair was dusty and knotted with the wind. Owing to the heat, I had also found it advisable to remove my collar and tie, so that the wind could circulate as much as possible. How could $I$ in such a condition maintain my self-respect in Washington, the magnificent capital of the United States ?

Fortunately, it did not take long for me to overcome such scruples. Another day or two on the road, and I was perfectly at ease during the intervals in which $I$ had intercourse with civilization. Occasionally I experienced a difficulty in entering a drug-store for an iced drink, and sometimes I felt a trifle shy at my bare, sunburnt neck, but no one seemed to mind. I soon found that in America, and particularly when travelling in the West, one could wear absolutely anything that one's fancy might dictate without rousing the slightest disturbance.

After satisfying my requirements at the "cafeteria," the second item on my programme was a visit to the Post Office. This revealed the sordid fact that there was no money awaiting me. It can easily be understood that such a discovery might have proved most distressing. I had been advised not to take much with me, but to cable for a draft from home at intervals. My adviser, as I was afterwards to find out to my cost, had overlooked the utterly chaotic state of the post-war transatlantic mail service.

I still had a little left, however, quite enough to get me comfortably to Cincinnati, my next financial depot, so why worry ? I could always work for a living, or at any rate, if I did not feel inclined to that, I might pawn something. 
I found a hotel that, from the outside, just suited my fancy. Plain, large and unpretentious, it described itself in an illuminated sign as the "National." I booked a room at three dollars (12s. 6d.) and sallied forth to see the sights.

I was impressed with Washington. It is truly a city of beautiful streets and magnificent buildings. Undoubtedly it is the city de luxe of America. Being the capital, wealth is lavished upon it. No factories or barren wastes disfigure its graceful countenance. Every street or avenue glistens at night with a bewildering multitude of illuminated signs. This method of advertising is typically American. The first impression of a stranger visiting a large American city at night is that he is in a children's luminous palace. There are illuminations and decorations of every conceivable nature. Sometimes a single sign advertising perhaps some particular brand of chewinggum or cigarette or motor-car has thousands and tens of thousands of lights wonderfully displayed in different colours and arranged in different series, one series flashing into view as another disappears, then a few seconds later giving place to another still more wonderful, and finally there comes a grand climax in which all the colours and all the series and all the figures blaze forth in an indescribable orgy of light.

When I found myself finally back in my hotel I was to be the victim of still another disillusionment. No country anywhere could rival America for hotels, I had thought. But I had not then experienced the "National " at Washington. The room allotted to me was literally an outrage. It was of the very poorest that one would expect to find in an East End boarding-house in the Old Kent Road. It had one window, which faced on to an unimaginably 
dreary "area." The carpet was threadbare and colourless. The furniture, consisting of one bed, one dressingtable, one wardrobe and one chair was obviously suffering from adranced senile decay. There was a washbasin in one corner that boasted of two taps and a piece of wood to stop the hole up with. The door showed signs of having been minus a lock for many a long day. I was too tired, however, to bother about trivialities of detail, so putting my revolver under the blanket near me in case of possible eventualities, I laid me down in peace to sleep.

Nothing occurred, however, to disturb my peace of mind or body throughout the night. The following morning found me hot on the warpath after a bathroom. After sundry peregrinations I unearthed a clue. It was in the form of a very corpulent negress-evidently a chambermaid. "Bathroom ?" "No, dere am no bathroom hyar," she informed me. But I persisted in my inquiries, suspecting her reply to be a mere excuse for sheer laziness. Finally, as a last resort, I absent-mindedly took my " life preserver " from my hip pocket and looked at it vacuously. Its effect was magical. "Yes, saar, yes, saar, come right hyar! - I find you bathroom!"

When I came to square up that morning I paid my respects and three dollars to the management.

"See here, Mister Manager," I said in such a tone that everyone within hearing distance had the benefit of it as well, "I've done a bit of travelling here and there, but never in $A X Y$ city at $A X Y$ time hare I struck $A X Y$ hotel that for sheer rottenness compares with THIs one!"

I hare an idea at the back of my mind that that managerman doesn't love Englishmen !

Now that I had seen America's capital, I turned my face to the west, and began to make rash estimates and frivolous 
promises to myself concerning my destination for the day. Could I get to Cincinnati next day? How long would it take to do the odd 550 miles or so? And what would be my reception when I got there? I had some friends in Cincinnati, friends that I had never even seen. What would they think when they saw THIs specimen roll up to their front door in Clifton Avenue? Was Lizzie going to stand up to it all right? When should I get to the coast? What kind of roads should I meet " out West" ? And so I wondered on. 


\section{EXCEEDING THE SPEED LIMIT}

I did not waste much time on the road. Fortunately there was a good proportion of concrete road, although the inevitable natural gravel was not by any means conspicuous by its absence. I also passed many stretches of brick road.

This variety is confined in England mainly to city strects, and is associated nearly always with trams. Not so in America. On the main roads of the East I have passed many a ten-mile stretch of splendidly paved highway made solely out of good red brick, and of the correct size and shape and camber of surface that literally made one's tyres hum and sing as each brick was momentarily touched in endless procession. I need hardly say that for every good stretch of brick road there are umpteEN bad ones though, just to add a spice of life a la grande route. Here and there one would encounter by no means solitary patches where apparently some enterprising farmer had torn up a few bricks from in front of some one's house to repair his cowshed or to build a new pigsty, or maybe to help put another storey on his house. There would seem to the lay mind such as my own to be a most decided disadvantage in this method of road construction! To put it mildly, it is disheartening when one is enjoying a fifty-mile-an-hour sprint on a straight stretch of road visible almost from 
horizon to horizon, to be rudely awakened from swift but peaceful contemplation of the beauties of nature, the loveliness of the atmosphere and the joys of motoring by being mercilessly thrown on top of the handlebars with one tremendous thump. At one spot of which I have very vivid recollections, the road took a short dip down and up again. In the bottom of the "valley" thus formed was a young but aspiring cañon where a wayward stream had left its prosaic path to strike out in life on its own across the road. Its presence was unfortunately undiscernible until close acquaintanceship was made.

When I came round I was vaguely conscious of something having happened, but as the engine was still running and the front wheel was still fairly circular, I got up and rode on, but not until I had arrived definitely at the conclusion that had I been doing sixty instead of forty-five I should have jumped across the bit of road that wasn't there and been hardly the wiser of it!

Here it was that I began to scratch crosses on the top tube to keep count of the number of times I was thrown off on the whole trip.

When the top tube got too short I put them on the front down tube.

When that was full I scratched them on the bottom tubes.

After that I trusted to memory. But that was when I got to the "Far West."

I made good time, however, in spite of an occasional set-back, and looked forward to completing three hundred and fifty miles that day. With luck I should reach Cincinnati the next, and then, oh for the joys of a good hot bath, clean clothes, well-cooked food, and last, but not by any means least, good company. And I wasn't 
forgetting either that I had only about twenty-five dollars in my pocket. With no mishaps I should have enough and to spare for even three or four days' travelling.

It was not yet midday, and the sun was getting very hot indeed. Moreover, I was getting hungry. Although I believe the two-meal-a-day system to be an excellent one, one sure gets a roaring appetite for breakfast at the end of a hundred-mile ride. So if $I$ had not a moral excuse for a little real speed work $I$ at least had a physical one. The road surface now changed from red brick to dazzling white concrete as in the far distance the Alleghany Mountains, that inexpressibly beautiful range that stretches parallel with the Atlantic coastline from Maine to Georgia, loomed gradually higher on the horizon, its varying tints growing deeper and deeper as mile after mile flew by.

There was hardly a soul on the road. Occasionally I would pass a touring car loaded up with human freight and with luggage bags, bandboxes and portmanteaux piled up and strapped (and sometimes I think glued!) to every available mudguard, wing or projection that was large enough to accommodate them and quite a lot that weren't. Then a hay wagon flew by, and then, after a few miles, a solitary farmer on horseback-not at all a common sight in this land of Fords and motorcars. And after a few more miles a tiny black speck came into view on the horizon. It took a long time to catch up. When I got closer I made it out to be a Buick roadster, its two occupants, a young man and his (apparent) fiancée, evidently enjoying a little spin in the country. And he wasn't crawling either. A touch of my electric horn (oh, a beautiful horn it was !) aroused his soul from its soliloquy and he drew in to the right, 
waving me on vigorously as he did so. And as I passed him he seemed to quicken a little. I glanced sideways for an instant and spotted a gleam in his eye. So I accepted his unspoken challenge and glanced now and then over my shoulder. He was hanging on well, his six cylinders to my four. A mile was passed and he was still just a little way behind. The road was clear and straight, so I opened out a little more.

Another glance. He was still there. My speedometer hovered around fifty.

Not to be outdone I twisted Lizzie's right handlebar grip as far as it would go, and like a bolt from the blue we darted ahead. Fifty-five, sixty, sixty-one, sixty-two, sixty-five. The wind was simply screeching in my ears.

Another glance back, our friend was slowly losing distance. A minute or two more and he was fast dwindling behind. In ten miles he was almost back on the horizon.

I had visions of breakfast in "Hagerstown," the next town of importance not so very far ahead. And so I forgot our friend of the Buick. In ten minutes' time I came to a village. As usual the good surface of the highway stopped and the roads through the town turned from the perfect concrete to an infernal hotch-potch of holes, gullies, ruts and mounds. Ironical notice boards warned the traveller that he must reduce his speed to fifteen miles per hour. It was purgatory even to go at four! To plunge into a seething mass of soil-waves at speed is disconcerting. It annoys you. But it is a custom that grows on you in Eastern America. You flounder about from side to side; you take a hop, skip and a jump here, there and everywhere; your very bones are shaken in their sockets ; your temper approaches a frenzy of despair ; and your language! 
Time was when I would blush with shame at the sound of a word that was bad. Then a war came along and I learnt to experience the soothing charm of an occasional flow of language. Occasionally I met a sergeant-major who could swear freely for five minutes without even repeating himself !

And then I motor-cycled across the States. And my heart rejoiced within me that $I$ had received such an excellent education. I found that with very little provocation or practice I could, had I the desire, have graduated to a very much higher stage of perfection in the United States than with the British Army in France. Indeed I will go so far as to aver that when ultimately I reached San Francisco not only could I have put to shame the most cultured sergeant-major that ever drilled recruits on a square, but in his moments of greatest enlightenment his powers of speech would have appeared as the futile prattle of childhood compared to what $I$ could have taught him.

So that is why I slowed down when I got to "Victorville."

In a few minutes, who should come alongside but our friend with the Buick racer. He slowed down and put up his hand. "Mind stopping here a minute?" he asked.

" Not at all," I replied, thinking he wanted to ask the way or borrow a sparking plug-or maybe beg a match. He got out of his car and came along.

"Say, d'ye know what speed you were doing way back there ?" he asked casually with a kind of ten-percent.-solution smile.

"Well, I don't know exactly, but I guess I got you beat, anyway!" I chuckled. 
Whereat he pulled a pocket-book from his coat and opened it. (Going to give me his card, thought I.)

"I'll trouble you for your number," quoth he, as he came to a page that was all nicely printed in columns ready for use.

From that moment I saw things in a different light. Verily the workings of the Law would seem to be getting interesting.

"And your licence, please?" after he had obligingly removed a layer of dust from my number-plate.

"What licence?"

"Your driving licence, of course. What y' think?"

"See here. Mebbe I do look a bit of a mug, but I do know you don't have to have a separate licence in New York State, s'long as your machine is registered. The number-plate is the same thing as a licence."

"Oh, is it ? I didn't know that." (Pause) "Well, do you mind following me a short way down the road-next block but one. It isn't far."

Whereat he got in his car again and moved slowly forward, while his lady friend protruded her arm from one side as if to stop me if I was inclined to dash past.

I did think of it in fact, because I knew I could give him a run for his money, but America, I recollected, was noted for its telephone service and I couldn't quite fancy having to resort to a hiding-place near the banks of the Ohio or perchance a field of corn somewhere in Indiana.

So I followed them down to the corner.

We stopped at a small wooden shanty on the door of which was a board bearing the sign "Daniel S. Tomkin, Aтtorney-at-Law." My friend the "speed cop" pushed open the door and ushered me into a passage. On the right was another marked "Justice 
Tomkin." "Come in : come in," shouted a shrill seedy voice as the "cop" knocked at the door.

"I've got a case for you, Judge," said he, when we got inside.

"Oh yes, oh yes!"- and then to me- "Take a seat, sir, please, and er-make yourself at home."

I'm afraid at that juncture I began to laugh. The "Judge" was just the kind of man that we love to see " on the pictures" in England, but who we never believe really exists. I had seen his prototype dozens of times before. Tall and wiry, thin legs and tight trousers, "Uncle Sam" physiognomy with the usual goat's beard and with stars and stripes printed in indelible ink all over him. He sat at a desk bare of papers, books, letters or other impedimenta. How long the desk had been cleared for action I know not, but his duties as a Justice of the Peace evidently did not involve any overtime from the look of things. The room was small and dingy and its walls were covered with shelves piled with books of all colours, shapes and sizes.

JUDGE.- " And what has this gentleman been doing ?".

Speed Cop (producing notebook and reading therefrom).- "Driving a motor-cycle in excess of the legal speed limit, namely at forty-five miles an hour."

JUDGE (after reaching from a bookcase a large red book marked "Laws, Bye-Laws and Regulations existent in the State of Maryland," or words to that effect)."I will proceed to read Statoot number 51, article 13, section 321b, subsection 2a of the 'Regulation of Traffic in the State of Maryland Act, 1898." "-(Submerged chuckle from self)-_"And it is hereby enacted that anyone found guilty of exceeding 25 miles per hour but not exceeding $\mathbf{3 0}$ miles per hour will be liable to a fine 
of not less than 5 dollars for the first offence and of $\mathbf{5 0}$ dollars for a second and any subsequent offence; and anyone found guilty of exceeding $\mathbf{3 0}$ miles an hour but not exceeding 35 miles per hour will be liable to a fine of not less than 10 dollars for the first offence, etc., etc.; and anyone found guilty of exceeding 35 miles per hour but not exceeding 45 miles per hour will be liable to a fine of not less than $\mathbf{2 5}$ dollars for the first offence, etc., etc." -(Considerable amusement visible on the face of self)" and anyone found guilty of exceeding 60 miles per hour will be liable to a fine of 100 dollars, etc., etc."-(Feeling of merriment subsides)- "but anyone found guilty of exceeding 60 miles per hour will be liable to a fine of $\mathbf{2 5 0}$ dollars for the first offence and of 1,000 dollars and imprisonment for any subsequent offence. I am afraid, sir, in view of the evidence and of the dictates of Statoot number 51, article 13, section-etc., etc., I shall have to administer the minimum fine of 25 dollars." (I breathe again).

SELF.- "Say, Judge, we seem to have got a bit ahead, don't we? Aren't I going to have a chance to say anything ?"

JudGe (a little "peeved." Evidently that aspect of the case hadn't occurred to him).- "By all means, sir, by all means. Say jest what you like."

Now I have neither the eloquence of a Disraeli nor the declamation of a Demosthenes, but I do claim to have no small power of persuasion when it comes to an argument or a question of opinion. So I mustered up every effort and summoned every resource to convince this malevolent Judge that he had been reading his "Statoots". upside down and that, far from being incriminated, I should, on the contrary, be granted a handsome award. 
I invoked the aid of every artifice known to humanity. Every inflexion of the voice; every modulation of speech; every appeal for sympathy, innocence, ignorance and youth known to me was conjured up.

And to what purpose? Did the Judge budge?-I might as well have read him Gibbon's Decline and Fall of the Roman Empire in five minutes for all the good it did.

"I am very sorry, sir," he said, "but the Statoot says that the minimum fine is 25 dollars, so it must be 25 dollars."

"But, my dear good Judge," said I, "I've only got about 25 dollars in the world at the present moment."

"Well, I'm very sorry, but the fine is 25 dollars"-(and then an afterthought)_- Oh! and costs as well."

"Costs!" I gasped in amazement.

"Yes, my costs will be 75 cents, and that makes 25 dollars 75 cents altogether."

Then ensued more argument, more persuasion, more eloquence, more appeals, but it was all in vain. I took out my wallet and counted out my belongings.

I had just 25 dollars and a few odd "bits."

And then the humour of the situation appealed to me once more, and stronger than ever before. I laughed at the Cop and I laughed at the Judge and I laughed at myself for laughing and paid over the 25 dollars 75 cents.

"Thank you very much. Good-day, sir," said the Judge as he put the "bucks" loosely in the drawer in his desk.

Here the Cop spoke up: "I have another charge against the defendant, of riding without his registration certificate, but it's getting late, and I think we might as well overlook it in view of the circumstances." (He was evidently thinking of his girl waiting outside.) 
I suggested it would be as well and left the Judge to gloat over his ill-gotten gains.

The idea of that goat-faced Judge and his sleek-eyed friend the "speed cop" having a good dinner together at my expense did not appeal to my better self. How was I going to travel 450 miles, buy petrol, oil and food with about tenpence in my pocket? On the opposite side of the road stood Lizzie with her carrier piled high and dusty, waiting, patiently waiting, for her lord and master. Ah, pathetic sight!-An idea-I return to the sanctum of the "Attorney-at-Law."

$\mathrm{He}$ was counting over the notes again.

"Say, Judge. S'posing you give me those notes back again. What'll it mean in imprisonment?" I had always since childhood cherished a wild desire to spend a night in prison. "The Statoot stipulates that there will be an equivalent of one day's imprisonment for every dollar fine." (Depths of despair once more, then enlightenment.) "Can you show me the statute that says that?"

"Sure," and he reached for the volume.

"All right, don't bother," said I, and left him once more to count his 25 dollars 75 cents.

Somehow I couldn't help laughing at everything. Such interesting sidelights into the workings of the ragtime laws of America are not met with every day of the year, I mused. But what fun to be all alone in America with nothing but a motor-bike and tenpence!

I guess the Judge was wondering what I was laughing at as he watched me through the fly-net at his window while I kicked the engine to a roar and rode away.

Truth to tell, I didn't quite know myself.

I was wondering when the petrol would give out. 


\section{CHAPTER V}

\section{ACROSS THE ALLEGHANIES}

Strange to say, I felt not the slightest bit "peeved" about this occurrence, but facts have to be faced, and anyone who has ever found himself in a strange land 4,000 miles from home, with a motor-bike and tenpence, will agree that something has got to be done about it sooner or later. All sorts of ways and means of making money quickly-the eternal problem!-occurred to me, but I dismissed them all for one reason or another. I could hold up the next car I passed and shoot the occupants after relieving them of their surplus cash. But that $I$ thought was a distasteful way of getting money. I had seen it done in the "movies," but decided to leave that modus operandi for a last extremity. What was it to be-a week's work or "trading away" the watch? I pondered. I got very little inspiration from my surroundings on a problem of such moment. Instead I was exhorted at almost every hundred yards to "Say it with flowers" or to "Chew our famous Smello'mint Gum." A huge yellow sign would then loom in sight bearing the legend "Playtime Biscuit." Every mile or so would appear another and more ominous inscription, "Sell it and buy a Ford." "For all internal ailments 'Kewrit' is the Sovereign remedy," blurted forth another placard. "The Sovereign remedy," I mused.-But say! What was that? The Sovereign remedy ?-Inspiration at last. Lizzie's throt- 
tle seemed to close its eyes with a snap. The brakes went on of a sudden and in a few moments I was taking off my tunic at the roadside. The memory had dawned upon me of a kind sister sewing some golden sovereigns in the lining of the belt of that very same tunic months ago way back in good old Brum. She had no doubt imagined me falling into the hands of Mexican bandits at some period in my peregrinations. At first I remembered I had protested against such a seemingly unnecessary precaution. Thank Heaven that argument against a woman is never of any avail!

I searched and I found; a few stitches carefully removed with a pocket-knife revealed two glittering " yellow boys" to my anxious gaze. On we sped once again, bounding, spinning ever faster onward. Truly we toiled not, but we sure did spin. If the sky was blue, it was bluer than ever before. If the road had been good, 'twas never so good as now. Refreshing breezes rolled down from the hills; sweet vistas sprang into sight; charming dells and streamlets flitted by, and never did the call of nature sound so strong.

And all because of two forgotten coins.

Hagerstown hardly welcomed me with open arms. A fair-sized, prosperous little town, it boasted a tramway service and two banks. My heart went not forth in joy at the contemplation of the tramway service. It did at the sight of the banks.

Dusty, dishevelled, and of dilapidated attire, I leant Lizzie up against the kerb and mounted the marble steps of the "First National Bank." The massive swing-doors frowned back as they squeaked and groaned to my command. I stood in the midst of a gilded palace replete with austere-looking deities in white shirt-sleeves behind marble 
counters and fancy-work grids. Nothing daunted, I flicked my precious sovereigns on the counter before the very quintessence of immaculate manhood with a "Change those, please" as if it were the kind of thing I did every day of my life.

Once upon a time I had often with swelling pride expanded my chest at the thought of a British sovereign being honoured in every country of the world and any corner of the globe. I had reckoned without Hagerstown. It seemed that the austere-looking deity before referred to was not at all impressed by my view of the situation. It must have been the personal tout ensemble that put him on his guard. He might oblige me by sending it along to New York to the Head Office, he said. "Couldn't wait a couple of days ?" he supposed.

It was no use. He didn't like my face and didn't want my gold.

I scraped the dirt from my boots on his marble steps and crossed the road to the "Incorporated Bank of Holland."'

After conducting a lengthy battle of argument and exhortation with all the clerks in succession and all to no avail, I began to realize that British currency was of no more worth than the little sea-shells that in the carliest days of trade were supposed to be used by the enterprising natives of prehistoric communities. With a gallant show of indignation $I$ demanded that the manager be produced forthwith. Strange to say, he appeared. I took him on one side and into my confidence. " Look here, old man," quoth I, "I'm in a bit of a hole. All your worthy satellites here think I'm a sort of cross between a rubberneck and a highway robber. Fact is, I've been rushed for speeding at the last village and I've 
only got two sovereigns to take me to Cincinnati. Now don't tell me you won't change them." Whereupon he looked warily at me and then at the gold, examining it minutely. "Guess I might fix it for you, but just hang on a minute till I can get some one to identify them. We never see such things as these, y'know."

In a few minutes he returned with an accomplice, who glared with amazement at the coins as they lay on the counter. "Gor' blimey!" said he, "don't that do yer blinkin' eyes good! Strike me pink, an' you've brought these ole yallerboys orl the way from England ?" and he picked them up reverently and gloated over their merry chinkle as he dropped them again on the counter. " Lor', I've spent many a one on 'em! How much d'ye want for them, gev'nor?"

"Four dollars eighty each," I replied.

"Done! Pass him the 'oof, boss. Nuthin' wrong wi' them."

Verily is it said that music hath charms for the savage breast. Once again Lizzie burst into a roar, and once again I turned her nose to the west.

Music ? That Cockney's dialect seemed like a wonderful fragrant melody pealing forth through the strains of a ponderous fugue. It was like a sudden rift in the thunderclouds through which burst a cheering shaft of sunlight. It was sacrilege even to think of those nine paper dollars that I had thrust so anxiously into my hip-pocket. "Thank Heaven there is at least one spot in the U.S.A. where the King's English is spoken undefiled," I murmured to myself.

The road to Cumberland was good going. We had now to commence crossing the Alleghany Mountains. 
This wonderful range, which also goes by the name of the Appalachians, has, in my opinion, no rival in the American Rockies as regards the loveliness of its scenery and the infinite variations of colour of its slopes. "The best scenery in the world, sir," an American would say, and he would not be so very far wrong either. Perhaps its heights are not so majestic as those of the Rockies; there may be no glaciers on its slopes nor crests of eternal glistening white on its peaks, but there is an unparalleled wealth of natural beauty in the blue and purple pine forests of its less aspiring heights and the myriad glistening streams and rivers that find their source in the thickly-wooded foothills clustering around its borders.

"Cumberland" is a comparatively large town in the middle of the hills and is well named. Undoubtedly the surrounding district reminded the early settlers so forcibly of our own lake district that they were inspired to perpetuate its memory, as they have done in so many other districts, towns and rivers in the far-eastern or "New England" States. Although the descent from the mountains was in places almost precipitous, the road was excellent, and excepting the concrete boulevards of California, afforded undoubtedly the best running that I met in the whole country. Although I stopped several times for considerable periods to allow the brakes to cool, there was nothing left of the brake-linings when ultimately I arrived in Cumberland, where I ministered adequate and well-earned refreshment to the inner man of both Lizzie and myself.

The road now lay clear of obstructions ahead and led over undulating country for several hundred miles. Once more thoughts of Cincinnati in the distance with a vague anticipation of something approaching "England, Home 
and Beauty"-and money as well-occupied the hours as we sped along, leaving the mile-posts quickly behind us. In places travelling was good. In places it was distinctly bad. Here and there were stretches of several miles of brick road, and now and then would reappear our old friend the "Natural Gravel," that so much conspired to make life on two wheels not worth living. At times even that provided quite a respectable surface. My firm intentions not to be baulked in my aim to reach Cincinnati next day, however, kept up the pace even if to our mutual discomfort, and made the going good.

At Uniontown, about seventy-five miles past Cumberland, various trivial little knocks and rattles in the engine disturbed my peace of mind. The speedometer registered only about 800 miles, and I had hardly expected to commence tightening things internally at that stage. A little farther on and one cylinder, after a few peremptory misfires, gave up the ghost altogether, and I proceeded a few miles on three only. I changed the sparking plug, hoping for better results, but in vain. After a few more miles I tried another plug and then another, but always with the same result. After travelling a few dozen miles in this unsatisfactory manner, I put Lizzie once again on her stand. This time I examined closely and found the valves, tappets and clearances all in good condition. There was apparently nothing wrong with the ignition either, or the carburettor, and there seemed no reason at all why such a trouble should arise-particularly, I reflected, as I was anxious to lose no valuable time. On trying still another plug out of one of the other cylinders and finding that No. 1 was still obstinate, I got on again, determined to do the 
journey on three cylinders only. I found I could touch well over forty-five even at that, so after all there wasn't much to complain about. Every motorist, however, who has a regard for his engine and can sense the "moral fitness" of even running and good rhythm will understand that travelling under such circumstances is decidedly unpleasant and monotonous.

At Waynesburg I passed Pittsburg some miles to the right, the "Birmingham" of America, the centre of a huge coal and iron industry and, next to Philadelphia, the largest town in Pennsylvania. A few miles farther on, and I crossed the border-line and entered West Virginia once again. It was now quite dark and $I$ had to pick out the road as best I could by my headlight. I was getting tired and was very hungry, not having had anything to eat for ten hours. After half an hour the headlight flickered and went out, leaving me with only a "dimmer," as the Americans call the small auxiliary light, with which to keep on the road and find the way. The engine, which before sounded pretty loose, now emitted noises signifying extreme agony of mind. Then a thick ground mist settled over everything, making it next to impossible to keep on the road at all, much less to keep on the right one. Occasionally I dismounted in an endeavour to bring the headlight back to life. Frequently I narrowly avoided being run down by large cars with powerful searchlights that couldn't see me at all. It generally meant pulling into the side of the road, getting off and waving my arms frantically to signify my presence. Between time I got more hungry and more tired, and kept asking myself the same question, "Why, oh why did I leave England ?" The answer always came: "Search me!" 
Shortly before midnight I reached the small town of "Moundsville," on the Ohio River and on the borders of West Virginia and Ohio. Every shop in the place was closed except that of a corpulent Italian dealer in bananas, oranges and ice-cream sodas. I entered his door with thanksgiving. The worthy proprietor scrutinized me open-mouthed. Finally he gave it up. I could see he had been wondering to himself, "What is this thing, and whence came it?" I sat on the counter in his presence and consumed three ice-cream sodas, four bananas and two oranges. After witnessing their consumption, he let drop his bottom jaw and ventured, "Whare yer from?"

"Doanchew worry your old think-box about where I'm from, brother, but just tell me where I'm goin'. I wonna get to Cincinnati. Now for the love of Mike don't tell me I'm not on the right road."

His jaw dropped through a further angle of ten degrees. Finally he volunteered the information that I was miles and miles from the road to Cincinnati, and that he hadn't the "goldarnest notion" how I should ever get back on it again. In disgust I filled my pockets with bananas and oranges and presented one more ice-cream soda to the minister for the interior and quitted his establishment.

My next duty was to find somewhere to lay my weary head. I decided to choose a spot where water was convenient, so that I could wash in the morning. The river was quite inaccessible from the road and the only places where there chanced to be a stream were infested with frogs and mosquitoes. After a half-hour of weary searching and climbing of long winding hills in the thick damp fog, I eventually gave it up in disgust. I found an open space at the roadside sheltered by a few trees, and here laid down my rainproof coat with the thick 
blanket doubled on top of it, and with my suit-case as a pillow, soon convinced myself that I was comfortably settled down for sleep. In a few minutes $I$ was well in the land of dreams. I dreamed that I was journeying to the North Pole on a twelve-cylinder Ford which went so fast that it melted the ice as it passed and ultimately crashed into the Pole at such a terrific velocity that the equilibrium of the earth was entirely upset, as also my own. At this point a lusty mosquito inflicted a tremendous bite on the very tip of my nose, and I woke up with a start. Then I dreamed that I had undertaken a banana-eating tournament with an army of Italians, and was just finishing off the ninety-ninth when another bite in the middle of my left eyelid brought me again to normal consciousness, and thus the night passed. 


\section{CHAPTER VI}

\section{THE DIXIE HIGHWAY}

In the morning everything was wet with dew. The mist was disappearing quickly, and I arose refreshed in body and mind. Specialists would have prognosticated acute rheumatism. Doctors would have foretold death within forty-eight hours. But I was never so free from rheumatism as I am now ; moreover, I live to tell the tale, with the probability of continued existence for several years to come. Lizzie looked disconsolate and rusty in every nut and bolt, but with a few kicks she rattled into life once more. The driver of a passing Ford informed me that I was twenty miles from the right road, which meant returning into Moundsville and crossing over the broad, muddy Ohio River, spanned by a lofty suspension bridge made almost entirely of wood. The Ohio River, once seen, is never to be forgotten. It is verily a flowing mass of dirty, yellow-brown mud. The natives of Ohio refer to it as the "Golden" River, I believe, but when I first made its acquaintance, I was in no mood to appreciate such poetic nomenclature. Instead I was bent on reaching Wheeling and breakfast.

Wheeling was reached in a couple of hours' riding along the banks of the river. It need hardly be said that I did justice to a substantial breakfast, which put an entirely new aspect on affairs in general. I struck 
the main "pike" through to Cincinnati, and continued hopefully on three cylinders with the best of intentions of reaching it that evening, although it meant a ride of over 300 miles.

I did 150 in fairly good time and reckoned on having my lunch-tea-dinner-supper meal at Columbus, the State capital, about five in the afternoon. But about twenty miles from that city a most distressing sound arose from the engine. I had previously slackened down to a steady thirty miles an hour so as to give Lizzie the best chance of holding out over the journey. But now a series of violent thumps and bangs disturbed once and for all my hopeful frame of mind. Undoubtedly there was a big breakage somewhere and it was evidently quite impossible to continue another mile. With a final thud the engine stopped and the machine came to a standstill near a little bridge where a tiny streamlet trickled under the roadway. Near the bridge was, as might be expected, the inevitable hoarding : "Sell it aNd Buy a Ford." Strange that Fate should at times be so ironical!

I made myself comfortable on a grassy slope and proceeded to take the engine down. This I soon discovered was no mean task. It took nearly three hours to remove the cylinders. Woe be unto the man hereafter who puts nuts where they cannot be loosened or places cylinders where they cannot be removed save by an Indian sword-swallower ! The result of my investigations was that $I$ found the front piston in fragments, mainly in the bottom of the crank-case. The gudgeon pin was broken in half and the connecting rod was waggling about merrily in the cylinder. All the bearings were loose, and although there was plenty of oil in the 
sump, one was devoid of metal altogether. This was discovered at the bottom in the form of powder. An encouraging outlook indeed!

Although my motto where a refractory motor is concerned-"to get it home somehow"-could have been ignored, I was not even in walking distance of anywhere. There was no town or village for miles around, and only a solitary farmhouse here and there. Further, an empty stomach does not improve one's outlook on life under such circumstances, and mine was very empty. I took stock of the whole situation. What should it be? Walk to Columbus and take the train, or stick by Lizzie and get along somehow? I counted out my money. It amounted to three dollars and thirty-five cents, not even enough for the railway fare. "No, I've set out to cross these infernal States on a motor-cycle, and I'll do it," I resolved, and sat down again to patch Lizzie's engine together.

The rumble of cart wheels on the brick road attracted my attention. The cart was drawn by a weary horse in the charge of a more weary driver.

"Hi, brother, got anything edible on board??" I shouted.

"I gotta lot o' old boots here," he replied, evidently in ignorance of the meaning of the word "edible."

"No, thanks, I gotta good pair of my own to start on before I come to that. Aincher got any oranges?" "Yep, I got one box left, four fer a quarter."

Bang went seventy-five cents for a dozen, leaving me with two dollars sixty. Now, thought I, I have enough provisions to last a couple of days. Let Old Harry do his worst.

The vendor of boots, furniture, and oranges went on his weary way. 
From a bough of a willow tree I shaped a neat gudgeon pin that fitted dead into the loose end of the connecting rod to guide it up and down in the cylinder. I fished out all the big lumps of the broken piston that remained in the crank-case and tightened up the bearings as well as I could. By the time it was dark I had everything replaced ready to start on the road once more.

Before daybreak, I was up and on the road; my plan was to keep on all day at a steady twenty miles an hour and reach Cincinnati about five in the afternoon. The machine ran well considering its wooden gudgeon pin, although it was not easy to avoid being reminded continually of Lizzie's indisposition, and as time went on the rattles became worse, the clanks became gradually louder, and I began to wonder where my next stop would be.

I passed through Columbus about breakfast-time, but did not stop for breakfast. There was no money for breakfasts. Now, although I did not stop at Columbus, I cannot with but a few words dismiss it entirely from consideration. Although not by any means the largest town in Ohio, it is the State capital. That feature, as I have pointed out before, is not at all unique in the States. In fact, I do not think I could name a single State capital that is the largest town of the State, without referring to the authority of one Baedeker. Not only are there over 125,000 people in Columbus, but it appeared to me to be a very fine city. The streets are wider and are better paved than those of most American cities, and in places are illuminated by large electric arches. Although there are seven towns throughout America boasting this title (each one in a 
different State), I think Columbus, Ohio, must be the elite of all the Columbuses.

Outside Columbus I stopped, had lunch-three oranges-and continued. There was really no necessity to stop, but I liked to feel that lunch was just as important an occasion as when it wasn't oranges.

The engine was by now getting rather noisy. People who passed in cars, many of whom I had passed two days before, slowed down as they approached and looked at me wonderingly, as if to ask if $I$ knew anything about it. They probably came to the conclusion that I was a deaf-mute.

Then we got to Springfield, and a noticeable feature at the side of the road, on a special track of its own, was an electric train service connecting up all the large towns in the district, even though the distances amounted to thirty and forty miles, in some cases even fifty, as is the case between Columbus and Springfield. Perhaps I am complimenting them by referring to them as trains, as they are more in the nature of single or double-coach trams, but I was surprised not only by the speed at which they travelled, but also by the number of passengers who availed themselves of the service. In a way, the presence of that track was comforting, particularly when some new noise or rattle emanated from my thrice-weary steed. On the other hand it is distinctly humiliating to be astride a 10 h.p. motor-cycle de luxe, jogging along side-saddle (to ease the growing soreness !) at fifteen or twenty miles per hour on three crotchety cylinders, when a tram-load of disinterested Americans flies past with a shriek at forty or fifty. Generally the driver realized the position and sounded a piercing whistle with a supercilious air, as if to say: "Make way for the fast traffic, please!" 
At Springfield the speedometer flicked off the 1,000th mile, and I branched away from the "Pike's Peak" Ocean-to-Ocean Highway (for such it appeared to be), and turned south-westward towards Dayton, a flourishing manufacturing and business centre. "Detours" and sub-detours were the order of the day and were conspicuous by their presence, as also by the general looseness and rottenness of their surface. In theory I was travelling upon the "Dixie Highway," reputed (by advertisements thereon appearing) to be "the finest and most luxurious highway in the States." As far as my experience was concerned, I found it paved with good intentions and bad cobblestones. Sometimes, when the paving blocks had been pulled up preparatory to new ones being laid down, the surface was tolerably good, but then would appear a "detour" heralded by an insolently-improvised notice-board which led the unfortunate traveller miles and miles from his appointed path and over the most disgusting road-surface imaginable.

I was pleased with Dayton. As I left it behind me, I wished it prosperity. It seemed to have the right kind of air about it. A friendly policeman held up a bunch of traffic for two minutes for me while he put me "wise" to the road to take. He noticed my New York number-plate and finished his chat with "Well, good day, brother, and the best of luck to you." I wouldn't even have killed a mosquito in Dayton!

It was now well after midday. Cincinnati was still about sixty miles away. Would it be safe to have a meal in the next town? I had filled up with "gas" and oil in Dayton and had about fifty cents (2s.) left. With a three days' diet of oranges, I had cultivated an appetite 
of great latent possibilities. I determined to be rash. Next stop, I told myself, I would look around for a "bakeshop."

An hour later I arrived at a little town called "Lebanon." It was very small, very picturesque, and very unpretentious. But it boasted an excellent "bakeshop." I leant Lizzie against the kerb outside and pressed my nose against the window-pane. The sight of all those nice cakes was almost as good as a feedbut not quite! I espied one, plain and large but tastylooking. I valued it at twenty-five cents. "Well, it'll last a long time," I thought, and entered meekly to inquire the price. "Five cents," replied the lady of the counter. "Done! It's mine, all of it!"

\section{Long live Lebanon!}

A few miles out, I halted near a bridge under which ran a little stream of crystal water. It was a treat to be out of the glare of the baking sun, so I sat down on the bank underneath the bridge and settled down in earnest to a sumptuous dinner. The bill of fare was as follows :-

Hors d'œuvres Gâteau de Lebanon (varié).

Consommé . Eau Naturelle.

Entrée . . Gâteau de Lebanon.

Plat du jour Ditto.

Légumes . Ditto.

Dessert . Ditto.

Wines . . Vin blanc d'Adam (direct from the distillery).

And oh, what a meal was there, my countrymen! There was enough and to spare. The cooking was excellent, the service irreproachable, and there were no gratuities.

After a leisurely half-hour I stuffed what little cake 
I couldn't contain into the tool-box, took one last, lingering draught from the cool crystal stream, and again kicked Lizzie into a rattle.

Once more towards Cincinnati! Two hours only, now, I reminded myself, and all the trees and birds in hearing. Gradually those two hours became shorter as mile after weary mile rattled past. Sure enough, in about the time I had reckoned the pot-holes in the road grew larger and the ruts deeper, a sure sign of approaching civilization. Then a huge signboard appeared, "CINcinnati, the Queen City of the West. Make your home in Cincinnati."

The Cincinnati Speedway was passed on the right, and after a couple of miles or more I struck tram-lines. The reader can well imagine how glad and relieved I felt when I spotted trams and tram-lines, those things which in normal life I rightly detest and abhor. Whereas once upon a time I considered them to be the motorist's greatest enemy, I now smiled upon them with friendly gaze.

By the time I was actually on the outskirts of the town, I was "baked to a frizzle." And such a thirst! For three days I had been amassing a good thirst. Ohio mud is not really a good beverage. It might perhaps "put one over" the "near" beer that I have tasted in various American towns, but that's not to be wondered at. The man who first called it "near" beer wasn't much of a judge of distance! Never could I remember having been so hot, so thirsty, and so fed up, all in one. I pulled up at the first drug store and literally squandered twenty-five cents in an orgy of ice-cream sodas. I took the precaution to retain ten cents, however, "in case anything turned up." 
At about half-past four WE ARRIved. A wealth of meaning rests in those two words. My friend Steve heard the noise as he sat reading on the verandah of 3,450 Clifton Avenue. "That can't be Shep. That's somebody wheeling a lawn-mower," he said to himself without looking-up, and went on with his book. But when the lawn-mower had overrun itself and turned round and came back and continued indefinitely to lawnmow outside the same 3,450 , he looked up and saw that it was indeed a motor-cycle or, at any rate, the unmistakable remnants of one. When he saw the rider, he thought : "No, that can't be Shep after all ; that's the dustman."

But fact will always triumph over fiction. In the same way soap, thank Heaven, will always triumph over dirt. But what a relief to be once again in a comfortable house, that could almost be considered " home," and once more to know the joys of a good hot bath and feel the luxurious embrace of clean clothes again! 


\section{CHAPTER VII}

\section{CINCINNATI AND ONWARDS}

I spent in all twelve days in Cincinnati. They were twelve happy days; days of leisure, days of interesting experiences, followed by days of longing to be on the road again.

The first of July, 1919, will live in the mind of every free-born American citizen as the day when Prohibition became law throughout the entire States. Not by design, but by coincidence, was it also the date of my departure from my friends in Cincinnati to explore the "perils" of the West. My sojourn there was brought to a sudden close by the astounding discovery that Lizzie's overhaul was completed. I had a few warm things to observe when I was presented with the repair bill. It amounted to a mere seventy-five dollars, half of which represented the alleged value of the somewhat indifferent labours of a more indifferent mechanic and a small boy. On the various occasions when I had visited the shop, the mechanic was generally conspicuous by his absence, and were it not for the occasional activities of the small boy, who seemed to delight in "salivating" at frequent intervals on every available inch of the floor surrounding Lizzie's remains, I feel inclined to think that I should even now be enjoying myself in Cincinnati. The other half of the bill represented sundry replacements which, to my way of thinking, should have been made free under 
the firm's guarantee, which had still three-fourths of its term to expire. After much argument, the proprietor and myself agreed to differ on this point.

The early afternoon witnessed my departure. The kindly attentions of mine hostess had provided me with good things for the journey. Meat sandwiches in boxes; fresh butter in tins; fruit and nuts galore. Little packages were squeezed in here and big ones strapped on there. Odd corners and crevices revealed an unsuspected orange or banana and hard-boiled eggs or biscuits in twos and threes lurked amongst the shirts and socks.

With a light heart I spun down the beautiful, wellpaved avenues that set at defiance the rigid, straightedge avenues of more modern American cities. I hummed over the cobble-stones of the lesser streets and swung past trams and over bridges and was soon speeding along the road to Indianapolis, thinking like a true pessimist that Lizzie didn't feel as well as I had hoped, and that I should be hung up again at a not far-distant date.

In America, in the east, it is the easiest thing in the world to take the wrong road. Moreover it is generally the most difficult thing to find out whether one is on the right road or not. I have no objection to make when roads in towns and villages will run either north and south or east and west, because for town life this arrangement spells efficiency. In the country, however, the raison d'etre of these chess-board roads is somewhat obscure. When combined with old-time roads that originally followed goat-paths or sheep-tracks, its effect is confusing. But when taken to the extreme, and one finds the main highways connecting large cities abound with sharp right-angle turns at every few miles, some- 
times going north to make up a little latitude, then continuing west, then returning south to lose the latitude gained, and afterwards continuing west again, the result is ridiculous and sometimes exasperating; very often two, three, four, or more roads run parallel and only a few yards distant, all leading to the same place. Sometimes they lead to different places. Sometimes they lead nowhere at all. Sign-posts are not popular anywhere in the United States. Instead the roads are identified by painting every third or fourth or tenth or $n$th telegraph pole with different colours. When properly carried out, this principle is a very commendable one, and without it travel would be absolutely impossible. But when followed only imperfectly, or when the colours become faded and obliterated, so that one trail can be easily mistaken for another, the traveller has many troubles and trials ahead.

I had ample moral consolation, therefore, for completely losing my way only ten miles out of Cincinnati, and wasted a full hour in trying to get on the right " pike" without going back.

Incidentally the system of decorating telegraph poles in accordance with the trail they follow has its humorous side. There are, all told, over a hundred different trails or "National Highways" in different parts of the States, and each one is supposed to have its distinctive sign. Thus the "Pike's Peak Ocean-to-Ocean Highway" is identified by a circle of scarlet above a circle of white, and the "Lincoln Highway" by circles of red, white, and blue. Sometimes, as in the cases of the "Blackhawk Trail" and "Mackinaw Indian Trail," the sign is of a more or less complex nature, including the profile of an Indian's head, for instance. The humour of the situation 
will be apparent when a single stretch of road coincides with say four or five separate trails. Each telegraph pole is truly a thing of beauty and a joy for ever, with its inscriptions, circles, squares, profiles, bales of cotton, etc., etc., painted on in various colours from top to bottom!

In large towns and cities where several trails meet, it requires the quintessence of alertness and deduction to find one's way by the telegraph poles, which, save for a few exceptions, represent the only means of identification. Strange, in a country using twenty times the number of cars per head found in any other country in the world, that facilities for using them should be so meagre as at times to be almost prehistoric!

It is strange also that some of the roads that were constructed even in modern times were the achievement of personal enterprise and are even now "boosted" and advertised by their "promotors." An outstanding case is that of the "Pike's Peak Highway" just mentioned, which is one of the three trails that cross the Continent from east to west. This road boasts a President, three Vice-Presidents, and a Secretary-Treasurer! Between them these worthy gentlemen are responsible for the proper maintenance of the road (experience compels a sarcastic smile), and for the furnishing of information to travellers thereon, etc. Where the money comes from I wot not, unless it be from the various motoring clubs in the country. In a booklet, published apparently by them, it is described as "The Appian Way of America." Permit me to quote passages from this remarkable publication:-

"Increased attention is this year being focussed on the 'See America' idea, and motorists planning a trans- 
continental trip will naturally select the route of greatest scenic and historic interest. That is why the discriminating tourist will travel over the Pike's Peak Ocean-toOcean Highway, the improved central route from the Atlantic to the Pacific coast. From New York it follows the National Old Trails Road to Indianapolis; from that city to Salt Lake City, it has its own Distrnctive Organisation; and west of Salt Lake City it follows the line of the Lincoln Highway. History places the stamp of approval on this as the Logical trans-continental Highway. Etc., etc. (pages of it). . . The trip has no dreariness and no monotony. . . . (More pages)."

Never was such a grossly misleading impression of ease, comfort, and luxury perpetrated upon an unsuspecting Englishman! It was well said that the pen is mightier than the sword. If ever again $I$ find myself so utterly demented as to motor-cycle across the United States before proper roads have been constructed, may Heaven preserve me from " The Appian Way of America" !

The reader may think that $I$ am dwelling unduly on the subject of roads, but I do so at this juncture because it was a subject which now became of increasing magnitude. Practically the last sign of paved road of any kind between this point and the Pacific Coast (some 2,500 miles away) would be encountered at Indianapolis, and from there onwards were universally the execrable "dirt" roads that so seriously threaten not only the comfort but the safety of motor-cycling. I was not even disappointed at the outlook, because I came to America without even expecting any form of trail or route across its entirety to be at my disposal. But I feel the natural resentment of the Englishman when I am led to believe that there is a luxurious "highway" ahead, only to 
find an aggravated series of dust-heaps, mud-pools, and cow-paths!

The road, however, to Indianapolis was not of the "Appian Way" variety. It was comparatively good in places, and ran for many miles along the valley of the Miami River, amidst beautiful scenery of ever-changing variety. After a few miles, the Ohio-Indiana boundary was crossed, and here, as many times afterwards, I was struck by the apparently sudden change of landscape, the same as the home tourist can almost always discern by the "feel" of the country whether he is in England or Wales, no matter if he be without his map for reference. I do not mean that either Ohio or Indiana is particularly mountainous. On the other hand, the latter is on the whole somewhat flat, as if in preparation for the weary stretches of monotonous prairie that are to be encountered the more one travels westward until the Rockies are reached.

I made little headway that afternoon, and at $\mathbf{1 0 . 3 0}$ in the evening I was still some distance from Indianapolis, the capital of the State. I therefore looked around as best I could in the pitch-darkness, with only my lights as a guide, for a likely spot for my night's abode. Water is a sine qua non for the camping vagrant, and when I came to a large steel bridge I decided that that was the place for me. It evidently spanned a pretty big river, but it was so far below, or seemed so far, I could not see the water. A lengthy reconnoitre from the road led me to the edge of a field of corn whence I could hear the river but could not see it for dense masses of vegetation.

I propped Lizzie up on her stand and found to my dismay that when the engine stopped the lights went 
out. Not feeling in the mood for investigating the cause of the trouble, I was satisfied to keep the engine running slowly as long as illumination was necessary in unstrapping my baggage and "making" my bed. Then I set out to find the river and enjoy the luxury of a wash.

Easier said than done! I could find openings in the thick undergrowth where I deemed the river should be, but could find no way of making closer acquaintance with its waters. As I continued my search, the bank suddenly gave way beneath me, and I was plunged up to the waist in the river I had been so diligently seeking !

My exit was more difficult to negotiate than my entrance. The bushes and weeds on the banks were not strong enough to enable me to pull myself out, but came away, roots and all, and left me sinking in the muddy river-bed. I eventually extricated myself, however, and decided to retire unwashed! Pulling off my soaking top-boots was a herculean task, and this done, I hung my wet breeches on a tree to dry in the warm summer night.

I passed a splendid night and awoke with the dawn, only to find my clothes wetter than they were the night before, thanks to a heavy dew. Such conditions, I reflected, were of mere trifling importance in the life of a bona fide tramp, and I was soon humming along once more through the fresh, crisp morning air.

We arrived in Indianapolis at breakfast time and with a hearty appetite. I remember Indianapolis chiefly as a city with long wide streets full of cobble-stones, tram-lines, and traffic policemen. My first duty was to take Lizzie to see the vet. I didn't like the sound of her at all, and she seemed but a rickety shadow of her 
former self. I was taking no chances now. As if by instinct we went "right there." The Henderson agent took Lizzie under his protecting wing, and while I settled down to consume a hefty breakfast of cantaloupe, puffed rice, and coffee, he took her for a spin along the few miles of concrete road that I had left behind with such regret.

"Waal, I guess there ain't very much wrong with her, boy," was the verdict, although he did not seem overexuberant about it.

"How far you goin'?" he added.

" Just to the end of the road," I replied.

" $\mathrm{Hm}$, and a tidy ride too, I'll say so. I've done it, but not on one o' them."

Then, after meditation, he added, "But I think she'll take you there. Give my love to 'Frisco, won't you, boy?"?

I promised, paid him a dollar, and left to track down the offices of the local branch of the " 3 A." Club, or Automobile Association of America, whom, I was informed, I must see before going any further, to inquire about the roads ahead. Dirt roads, it will be understood, vary with the weather. Hardly ever does the English motorist hear of a road being washed away with the rain, but the idea of its being borne away on the wings of the wind would indeed appear strange to him!

I found the " 3 A." Club located at one of the large hotels, all alive with "bell-boys" and commissionaires and elevators. I was greeted by the hotel staff with haughty aloofness. "Put that gink outside," I could imagine the desk clerk saying to the hall-porter. But I was being whisked up the elevator to the umpteenth floor before he had the chance.

At the " 3 A." Club office I was greeted most cordially. 
The gentleman at the desk was a human encyclopædia of roads and places. Beneath the dirt and dust he believed he perceived some person of high rank, a brigadier or something, and my brown tunic and fieldboots must have borne out this assumption. However, that may be, he certainly did his best to give me every assistance. But when I told him I was motor-cycling to the Pacific and wanted to know which was the best road to take, his jaw dropped suddenly. There were two alternative routes to Kansas City, the "Pike's Peak" through Springfield and the "National Old Trails Highway" through St. Louis. Which should I take?

"Well, sir, the National Old Trail is impossible just now. The rains have been very heavy and there are several places where you couldn't possibly get through. And as for the other-well, I shall have to think."

Which he did. He hummed and ha'd and stroked his chin and hummed and ha'd again, as if struggling with some momentous problem. He spread out maps in rows before him and followed the route with his finger. Then silence.

After a minute or two of this, in which the merits of "washouts" and hold-ups and detours by the score were being weighed together in his troubled brain, he spoke :

"Yes, sir, I think you can get through"-and, more deliberately-"I think you can get through. Yes, it's a good road," he added.

I learnt then for the first time one outstanding principle in the road-study of America. I confirmed it on innumerable occasions later. There are two classes of roads and two only. They are good roads and bad roads. Any road, ANYwHERE, in the whole 
of the United States of America (and, I presume, her Colonies as well) is a "good" road if you can "get through." The remainder are bad.

I thanked my benefactor and accepted sheaves of maps and guide-books for which he would take no payment. He was indeed the quintessence of obligation. I on my part was the quintessence of gratitude.

"Now for the fun," I chuckled as I kicked Lizzie to a roar and set out for the highway with red-and whitecircled telegraph poles. 


\section{CHAPTER VIII}

\section{INDIANA AND ILLINOIS}

The first bit of fun was not far ahead. In places the road was passable if one ignored the six-inch layer of loose sand and soil that covered it. The country was flat and uninteresting. Diversion was occasionally encountered in the form of side-slips and here and there an unexpected spill. The quicker I went the easier I got through, as the soil did not cling to the wheels so much and hinder steering. At thirty it was almost impossible to maintain balance. At thirty-five it was tolerable, and at forty it was comparatively simple.

Now and then I would pass a kind of harrow the width of over half the road and drawn along by a team of horses. The function of this was to break up the big lumps of solid mud formed by the recent rains. After this would follow a similar team of horses dragging a "grader"-a kind of snow-plough arrangement which scraped the surface flat and shovelled the surplus sand and mud-lumps into the side. In these districts the farmers are held by law individually responsible for the condition of the roads their farms adjoin, and the process of grading is expected to be carried out within three or four days after the rain. When the farmers are busy with their crops this doesn't get done, and when they aren't, it sometimes does, according, I think, to whether the farmer is a sheriff or a justice of the peace and has 
to set an example to others. Fortunately all farmers are motorists as well; they have to be able to get about, so when they wish to travel, they grade the roads for their own use if for no more altruistic object.

Once I was passing one of these road-ploughs drawn by a team of three horses abreast, which took up most of the road and showed not the slightest intention of drawing in to the side. In endeavouring to pass it, I struck at too small an angle the huge ridge of solid mud-lumps that it had formed. I was going fast, of course. The handlebar was wrenched out of my hands and I was thrown with great force over it and on to the bank at the side. Lizzie herself lay roaring on her side in the dirt. The horses took fright and galloped off. The only damage done showed itself in some nasty cuts and scratches, some small areas of skin missing from different places, and a few bent levers and controls. From past experience I had learnt that in all such cases the clips and brackets and sharp corners of Lizzie's profile always seemed to be in the path of my flight over her handlebars.

A handkerchief bound tightly round the cuts, a few adjustments made, and on we go with smiling faces, only to overtake the wretched thing again!

After twenty or thirty miles of this, we came to mud in earnest-mud measured not by the inch in depth, but by the yard. Never was it soft and squishy and respectable, but always baked rock-hard into ugly contorted shapes that simply defied progress on two wheels alone. The diabolical effect had been heightened by the passing of numerous cars through the roads when the surface was still plastic, and great ruts and cracks and ridges were thrown up at every point between the road- 
boundaries, each one representing an eternal struggle to "get through." When the fierce sun came out and poured down for days unceasing upon such ugliness as this, the hideous surface was as if petrified by its glare, and the efforts of a "grader" would be futile to alter in the slightest degree its abominable condition.

Riding was out of the question. It was haulage work that had to be done, and many times when I got into a huge solidified "crevasse," I had to leave the machine standing in it on the tubes of its cradle-frame and proceed ahead to chip the edges down until the wheels would reach to the bottom again.

Anyone who has stood on the "Glacier des Bossons," looked upwards towards the summit of Mont Blanc, and seen the contorted, fantastic shapes that the ice assumes as it swells over the ridges in its path, can perhaps imagine the same effect on a smaller scale applied to the dirt roads of Indiana.

Fortunately there were stretches of road, generally when there was a slight gradient, where the surface was well-drained, hard, and flat, and going was good. But invariably at the foot of every slope, or at the dip between two hills, there was a stretch of excruciating "agony" that would reduce the most defiant motorcyclist to submission.

Thus it was for eighty or ninety miles. The truth began to dawn on me that a fellow has to be a "tough guy" to motor in these parts. Sometimes I would stop and rest awhile to let an occasional car get by. It was funny to see how they all went! The big heavy touring car would roll along as if to devour all that came its way. It would meet a nasty patch and with broken dignity would heave and sigh from side to side as it 
slowly crawled on bottom gear over the ridges and furrows; and then it would rear proudly into the air as it surmounted some huge lump of solid mud and suddenly flop down with a dull thud on the bottom of the springs as it plunged into the hollow beyond. One could hear every joint groan under the strain and could sometimes see the bottom of the engine scrape ridges in the chunks of earth and watch the little bits knocked off an unfriendly obstruction as the back axle dragged its weary way along.

And then perchance would come some cheeky Ford, the essence of impudence as opposed to the dignity of its wealthier brethren. With a hop, skip, and a jump, it would scramble over the furrows, swinging gaily from side to side, wagging its tail in the air and rattling in every sinew as only a Ford knows how! But the "Flivvers" got through easier than any.

The worst patch I struck was near the small town of Hume. I have never seen in the space of 200 yards a more apt imitation of a volcanic lava-bed. The thick mud of two days before had been churned up into the most fantastic shapes that ever a main highway has taken. Every square inch of the ninety-foot-wide road bore signs of the passage of some vehicle or other. Some of the ruts were so deep that the machine rested on the engine and the frame and not on the wheels at all. Pushing it anywhere but in one of the best ruts was impossible. When the rut got too deep, I had to lift up the back of the machine bodily and wheel it foot by foot, while the rut took the front wheel whither it listed. Here and there were signs where car-drivers, in similar predicaments, but a day or two before, when the mud was not yet baked quite hard, had shovelled 
away large quantities of the road to allow the engine and chassis to clear. Half-way through was a large hole, deep and broad enough to allow a small car to be hidden therein from view. In this hole the mud was still soft and plastic. A good Samaritan of the road had procured a piece of old corrugated iron from somewhere and propped it against two poles to warn any others who might follow of its presence.

Lifting four-cwt. Lizzie across this whole stretch took three-quarters of an hour all told, and at the end I was faint with exhaustion. The sun was never hotter and I never perspired more, not even in the middle of the Mohave Desert in California, where the thermometer rises up to 140 degrees or more! I begged a glass of milk from a farmhouse a mile farther on, and thanked God that He made cows and that I was still alive to appreciate them!

And thus we toiled and thus we spun for many miles until late in the afternoon, when I came to parts where the sun had not yet had time to do its work. Every inch of the road was thick, black, slimy mud; mud that stinks with a smell peculiar to itself alone; mud that clings to the tyres and wedges in the forks and fouls the chains and blocks the wheels; mud indeed that sticketh closer than a brother. I stopped at a ramshackle little village of a few dozen shops and houses, all made of wood, and boasting the name of "Murdock," to partake of afternoon tea. Outside an old rickety "store" (this term includes any conceivable kind of retail shop in America), I saw a notice: "Henry T. Hodges, Justice of the Peace; Dry Goods Store; General Merchandise; Post Office; Real Estate; Refreshments."

Henry T. Hodges beamed on me benignly from behind 


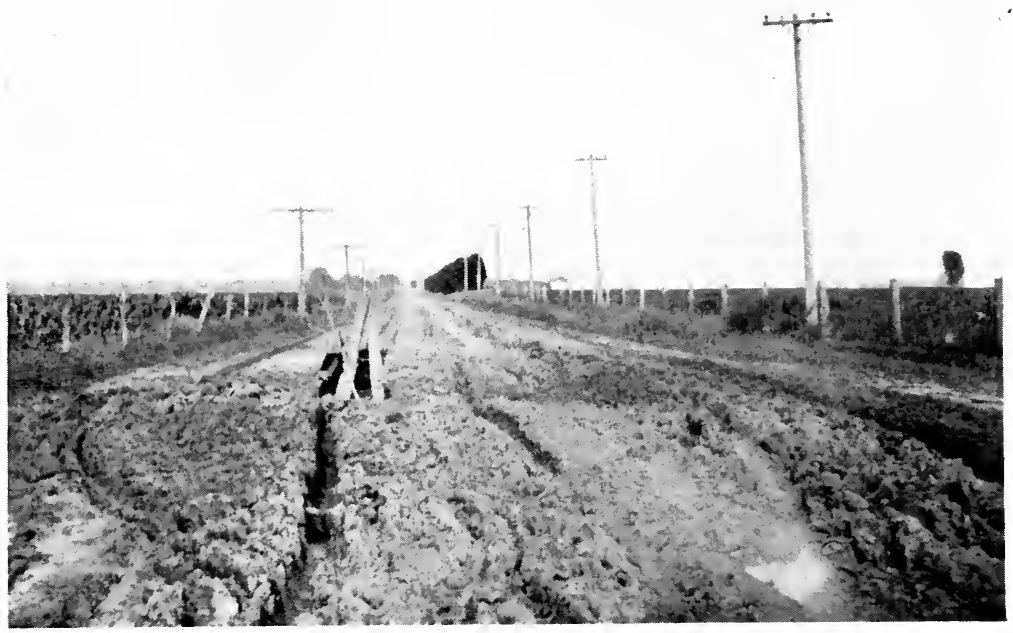

AN AWKWARI) STRETCH OF ROAI IN INDIANA.

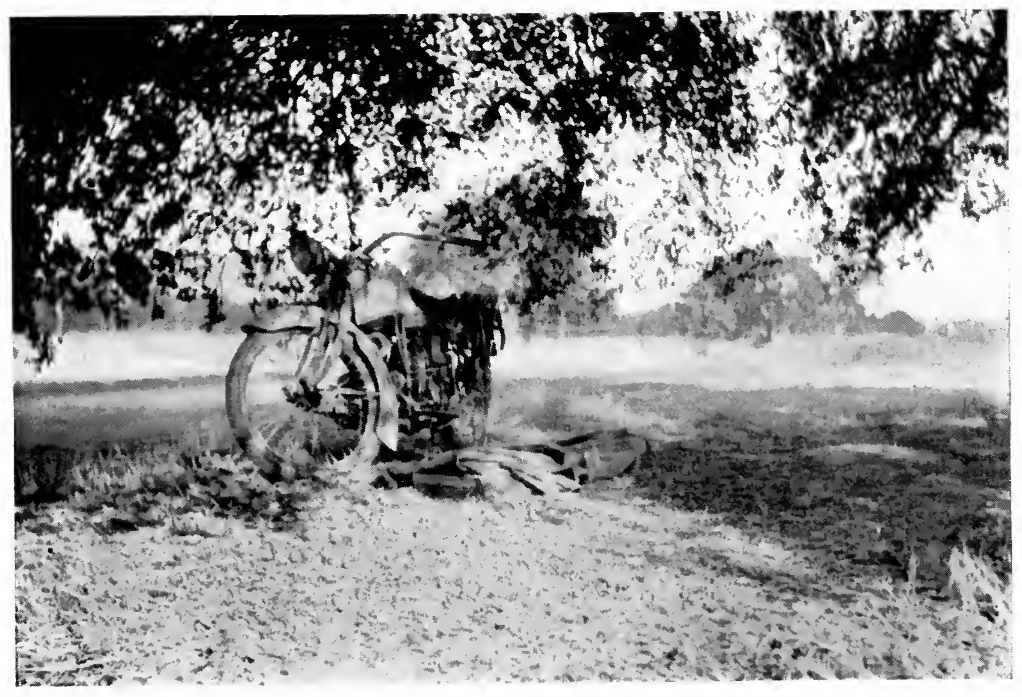

The MuNight Couch. 

a pile of preserved fruit tins as I entered his gloomy establishment.

" See here, dad, I want a good meal," I said ; " money's no object. Get me?"

"Sure; an' have ye come far, brother?"

"I should reckon about a thousand miles to-day. Dandy roads you've got in these parts, dad."

"Aye, but you'd 'a seen 'em when we 'ad the rains, brother; they wuz so mighty slick the hottymobiles sunk right down in 'em and 'ad to be dug out wi' a shovel and dragged along wi' a team of four 'osses."

"Why, I shouldn't have thought there were four horses in Murdock," I replied.

"Aye, an' I know there is, brother, 'cause they're my 'osses."

"Um! Guess you make a pretty good living out of them, don't you, dad ?"

"You've said it, brother. Ten dollars a time is my charge, and if a chap don't pay I jest leave 'im there till 'e does!"

"Well, what about this meal, dad? I'm mighty hungry - and, say, who's the road commissioncr about here?"

He essayed no answer, but disappeared hurriedly to boil the tea. I had no doubt now who the road commissioner was!

After leaving the "Store" of Henry T. Hodges, J.P., I did another twenty miles or so until dark, and sought out a comfortable secluded spot near the road, but far enough from it to avoid the smell of it, and settled down for the night. Mosquitoes were the only source of worry now. Otherwise this roadside sleeping was getting quite a commonplace event. 
Up at dawn in the morning! On the road once again ; labouring, pushing, hauling, heaving, lifting, cleaning off the mud, speeding a mile or two and then more labouring and more pushing.

At breakfast-time I reached Decatur, a flourishing town of 20,000 or so inhabitants, and had breakfast at a "get-fed-quick" eat-house where you sit on a stool in front of the counter and the man at the range behind fries you a mutton steak, bakes the "waffles," or poaches the eggs as per your desire.

Then on again towards Springfield, the capital of Illinois State. The mud changes to sand and the sand to dust. More spills, more cuts, more bruises. The country as flat and uninteresting as they make it. More right-angle bends, more losing of the way and more frizzling in the sun. Two villages are passed in forty miles. One has a population of 417 and the other 59 .

At 11 a.m. we draw into Springfield, hot, tired, dusty, and sore. Springfield is a mass of roads, trams, telegraph poles, and people. I leave Lizzie leaning against the kerb and go for an ice-cream soda; when I return, Lizzie is no longer visible. Instead there is a large crowd. They are all examining something. Those on the outside elbow their way to the middle. Those in the middle try to keep them out. The passers-by wonder what it's all about and stop to see. They in turn try to make their way to the middle. Many are disappointed and pass on. The traffic cop, seeing the crowd, strolls over to see what's wrong.

When he had moved the crowd away, I got astride Lizzie's saddle and rode away, amid murmurs of astonishment.

"Come quite a ways, I reckon." 
"That's the kind of bird to go travelling on."

"Looks as though he's seen some mud somewhere."

"Look, Bill, he's got 'igh boots on like they have in the movies!"

"Ah, that's what 'e is, 'e's a dolgarn movie actor," etc., etc.

All the trails in America seem to go through Springfield, Ill. Consequently the telegraph poles and tram poles were a mass of hieroglyphics. It took a few minutes to get into Springfield. But it took the best part of two hours to get out of it satisfactorily. Once I thought I was well away, but found that for ten miles I had followed a trail that had white stripes on a red background instead of red stripes on a white background, or something of the kind.

Jacksonville was the next town, some forty miles away. There are six smaller towns on the way. I don't remember passing six, but my map vouches for this number. Their respective populations, taken from the said map, are as follows :-Riddle Hill, 25; Berlin, 251; New Berlin, 690 ; Alexander, 200 ; Orleans, 38; and Arnold, 15. So America is not full up yet. But fancy showing a village of fifteen inhabitants on the map! If it were in Arizona instead of Illinois they would have called it Arnold "City." Here are some more names, taken at random from the map, to show the endless variety that the American cartographer has drawn upon:"Daisy," "Whitehall," "Quiver," "Cuba," "Golden," "Siloam," "Time," "Pearl," “Summum," " Birmingham" (population 76), "Illinois City" (population 80), "Bible Grove" (population 10), "Enterprise" (population 7).

After Jacksonville the road seemed to change its mind. 
It refused to be a road any longer. It turned instead into a sea-beach and dodged in and out, here and there, to evade the approaching traveller. Everywhere was to be seen white sand. It lay feet deep on the trail, making progress almost impossible. It covered all the vegetation at the roadside, and it filled the air as well. Here for the first time I encountered the type of road that can disappear with the vagaries of the wind. It was easy to imagine that in æons of time this self-same road would help to form some great geological strata deposited in the Gulf of Mexico or elsewhere. The country became hilly and thickly wooded, and sometimes the trail would narrow down to just a few feet in width and then just as quickly open out to fifty or sixty. The trees grew thicker, the sand grew thinner, the trail dodged around boulders and trees, shot up little sandy slopes, and then, all of a sudden, without any warning whatever, stopped at the bank of a great wide silent river.

It was the Illinois River, a tributary of the great Mississippi, which itself was only fifty miles away. About a couple of hundred yards wide, it was navigated by a ferry-boat of unknown antiquity pulled across the river by a cable wound round a drum. Every man, woman, and child, and every vehicle that crosses America by the Pike's Peak Highway, swells the funds of the man who owns that ferry-boat.

"Which is the road now?" I asked him when we eventually reached the other side. I could see no signs of any continuation of the trail. He had better eyes than I, however.

"Go straight ahead; you can't miss it."

There was certainly visible a little pathway that 
scrambled up the bank and then wound in and out among the trees, and as I could see nothing else, I followed it. Sure enough it led to "Valley City" (population 52), and thence onwards, through "New Salem" and "Barry" towards "Hannibal" on the Mississippi River.

The Mississippi ! Long had I conjured up visions of this mighty river of over 4,000 miles total length that cuts through the United States from north to south, and drains nearly $1 \frac{1}{2}$ million square miles of land! I had imagined its vast breadth and followed in my fancy the great, silent, moving river as it flowed from west to east and north to south through ever-changing scenery and ever-widening banks. And here I was within a few miles of it! The thought was almost absurd.

Just when the sun was about to set the road made one more swerve to the left. The trees and the surrounding country fell away as if by magic, and there was nothing beyond, save a massive bridge of steel. Beneath and from horizon to horizon flowed the majestic river.

The other end of the bridge was probably some 3,000 feet away in the town of Hannibal and the State of Missouri. Hannibal bristles with statues, tablets, posters, placards, and picture-postcards. They all have the same theme for a subject-"Mark Twain." The Hanniballians, if such they are called, are just as bad. I believe it is not possible for a stranger to be in Hannibal for five minutes without being told that Mark Twain was born there. If the "clerk" at the refreshment bar doesn't tell you, the man at the post office does. If the young "fellar" who pumps a couple of gallons of "gas" into your tank forgets to tell you, the old girl 
at the fruit-shop doesn't. They must have a secret code in Hannibal whereby they arrange these things. And I will guarantee there aren't two out of every dozen picture-postcards on sale in Hannibal that don't show Mark Twain's birthplace or his cave or his statue or his ass or his ox or something that he either did or did not " immortalize."

Seeking a quiet little spot by the river where I could spend the night and fulfil one of my long-cherished hopes - to bathe in the River Mississippi, I turned down a little road that ran along the bank and reconnoitred the country. To my dismay a railway ran between the road and the river, almost at the very water's edge. Nothing daunted, and hoping that it would sooner or later swerve away and leave me in peace with my river, I continued for miles, long after it was dark, but with no success. The road itself was on a ledge high above the railway, and the railway was on a ledge built some six or eight feet above the river. Eventually I left Lizzie at the roadside, camouflaged her with leaves and branches, and scrambled down with my bags over the ledge on to the bank below. I found a comfortable little spot about ten feet from the rails and laid my bed. And oh, what a glorious bathe $I$ had in the river!

It was the eve of July 4th, the American "Day of Independence." Sounds of revellers from far away were wafted over the calm, silent waters. Now and then would be heard the faint swish of a canoe as it glided past in the darkness of the night, and soft music crept up the river from time to time, now clear, now faint, as if from its dark and mystic depths.

I tucked myself under the blanket feeling like a good Christian that night, with never a worry in the world 
-a world that was good and kind and comfortable always.

Nevertheless I should have liked to know when a train would be coming past to disturb my slumbers.

Just as I was dozing over, I heard footsteps along the rails. They came closer and closer, but I could see nothing. The night was pitch-dark. As the footsteps came opposite to me, I made out the form of a man against the starlit sky. He did not see me.

"Say, bo, can you tell me how many trains pass here to-night?" I asked.

He jumped as if struck in the back.

"Only a couple, brother," he replied to where the air had spoken, "one of them in about half an hour and the other about one in the morning;-but they won't worry you," he added.

Sure enough in half an hour's time I heard the distant rumble of a train. I began to wonder if I had not rolled any closer to the rails than when I lay down. The earth shook and a red glare appeared in the distance, and with a mighty roar the huge train came thundering through an opening in the trees. Although $\mathbf{I}$ knew I was at a safe distance, the feeling of impending annihilation swooped suddenly down upon me. "Don't be an ass," said I, "what's the use of getting the wind up ?" And the next second it seemed that the rushing torrent of steel and fire was but an inch from my head. Clatter bang-thump, clatter-bang-thump, for twenty long seconds, and the intruder was gone. In another minute not a sound broke the silence of the midsummer night.

Thinking what an excellent test of self-control it would be to pitch my bed between the rails, but disinclined to do so on account of the possibility of a cow-catcher 
being in front of the trains, I rolled over into heavy slumber.

In half an hour I was awake again and the same process was repeated. I deemed then that I should be left in peace for the night. But my friend had not reckoned on the freight trains. Only the passenger trains were of account to him!

Regularly every half-hour they thundered past. At dawn I had counted thirteen in all. I resolved not to sleep on a railway embankment again, even though it be in company with the Mississippi. 


\section{CHAPTER IX \\ STORMY WEATHER IN MISSOURI}

Hannibal is a nice, clean, respectable place; were I an American tourist I would call it a "cute little city."

I found an eating-house with a tempting smell around it, and ordered a hearty breakfast. After polishing off this meal, I mounted Lizzie and started off once more.

We were now in Missouri, the State of the small farmer. Not that the farms are so very small, but they are not on so large a scale as further on in the west, where the hundred-square-mile ranch is the order of the day.

Again the scenery experiences a quick change; the country becomes hilly and rough ; one sees maize growing almost everywhere and very often pigs (or hogs as they are termed in the States) turned out to pasture. Nevertheless there is much uncleared and uncultivated land to be seen; the towns and villages are clean, modern, and well laid out, and all give an air of prosperity and plenty. Every farmer has his car, and it is generally a Ford; youngsters of twelve and fourteen can be seen driving them, and generally with as much skill as their parents, if not more.

But for all its hills and vales and the luxuriance of its natural beauty, Missouri has one great drawback. There is a very big fly in the Missouri ointment-RaIN. And when it rains in Missouri, it rains properly, not in tantalizing little showers as it does in England. It is 
as though the whole sky had burst its water-mains. It falls not in inches but feet; not for hours but for days. Then suddenly the sun breaks out and scorches everything with renewed vigour. If a car is out far from home when the rain comes, it generally has to "stay put." The rain sinks into the road and so does the car. Every car carries a set of chains for its wheels, but although they improve matters slightly, they are often futile in ploughing through the thick slime. Then come the teams of horses at five and ten and twenty dollars a time to drag the unfortunate automobile to some garage where it "lays up" until the rain has gone and the sun has dried the roads sufficiently for further progress.

Sometimes enterprising individuals do not wait for rain to bring in the shekels. I have often heard of perfectly authentic cases of a farmer deliberately flooding likely patches of the road and then waiting patiently with his horses to drag out some unfortunate victim. This seems absurd, but care is always taken to select a spot where it cannot be definitely proved that natural conditions are not entirely responsible for the result!

In the early afternoon, after a hard ride from Hannibal, punctuated at every village with a stop for the consumption of ice-cream, I reached a small town called "Bucklin." No sooner was I there than a huge black cloud appeared suddenly in the sky and a terrific windstorm rose which blew everything that was not fixed to something in all directions. For half an hour it raged. The air was thick with dust, leaves and bits of paper. Then, as suddenly as it had come, the wind subsided, and rain commenced in torrents. So fast did it fall and so heavy were the drops that the surface of the road was beaten into a froth which hovered all the time a few inches above 
the road itself. Even to walk across it was a test of skill ; so slimy was the mud that one's feet slid aimlessly about in any direction but the one desired. For this reason concrete pathways are invariably provided so that pedestrians can move with comparative ease and can leave their homes and visit anyone anywhere in the town without actually touching the mud at all. These concrete pathways naturally have to cross the road in places, and when the road surrounding them is washed away, as very often happens, the result to a passing vehicle can be imagined.

Further progress being out of the question that day, I hied me to the only hotel in the place and prepared to while away the days that were to follow in writing letters, studying an obsolete almanac, and eating bad food.

It rained in a continual deluge all that day, all night and all next morning. At midday it stopped with a bump, the sun came out with another, and the birds began to sing again. At three $I$ ventured forth with Lizzie. I had not gone a dozen yards when the back wheel slipped sideways round to the front and left me reposing in the half-baked mud. Back again for another hour's wait while the broiling sun did its work. Next time I got as far as the outskirts of the town before I decided to turn back. After another hour we started out to do or die, come what might. During the remainder of the day until dark we covered ten miles, going hard all the time. When I was not extricating myself from a spicy bit of quagmire, I was poking semi-hard mud out of the wheels and mudguards.

On one occasion I came to a sudden dip in the road, followed by an equally sudden rise. As usual there was an uninviting "slough of despond" in the hollow. 
After trying two or three different ruts in an effort to "get through," giving up each one in turn as hopeless, and pushing back again to where still another rut branched off from the one I was in, I eventually worked my way through. The struggle up the slope on the other side was a formidable one and was being slowly accomplished by a combination of bottom-gear driving, pushing, lifting, and "paddling." Just before the summit was reached I was thrown by a steep furrow into the ditch at the roadside, breathless, exhausted, and extremely bad-tempered.

As I was extracting myself, a young man in shirtsleeves strolled leisurely over, hands in pockets, from a stationary car a little further on. When I had safely extricated my right leg from under the machine and hauled Lizzie on to her wheels again, the stranger spoke.

"Say, fella, does that front cylinder get hot? I've heard say that's the weak point about them four-cylinder motorsickles."

Here follows a flow of language from self entirely unprintable. The stranger opens his eyes, whistles softly, then adds, as if to turn the subject:

"Where you from?"

He remained with his hands in his pockets staring at my diminishing form. He was still there when I looked over my shoulder half a mile further on. He is probably there now !

As time went on, black clouds appeared in the sky; the sun went in; the wind rose, and a repetition of the events of the day before commenced just as I arrived in the small town of "Wheeling." The only thing to do was to eat ices until the climatic conditions adjusted themselves. This took the best part of two hours. Once again I sallied forth with Lizzie. This 
time in the short space of five yards I reposed gently but thoroughly in the Missouri mud, much to the amusement of the population, who had all turned out to witness my departure. Again I tried and again I fell. The whole machine seemed to act as though it were made of jelly. I gave it up on the third attempt.

"Try the railway," jeered the village comedian, pointing to a level-crossing in the distance. This amused the onlookers " considerable." For myself, I discerned a glimmer of wisdom in the suggestion.

"Look here, you guys," I retorted, "what about giving me a hand to push this as far as the depot" (I never made the fatal mistake of referring to it as a "station") "instead of looking on and grinning like a lot of schoolboys?"

It had its effect. Three or four volunteered at once. We all pushed; we slithered to right and left; we slipped over each other and ourselves. But we got there.

Riding on the sleepers was hardly humorous, but it was better than the road. They were not filled in and were very irregular. Consequently progress was slow and a trifle disjointed. The "depot" was not far away. The "line-boss" looked at me curiously, as though I were a strange offshoot from some wayward train.

"Many trains coming along this way?" I queried, wishing to know what I should have to meet, as there was only a single track, double tracks being seldom, if ever, laid in the States, and if one was unprepared it might prove embarrassing to meet a train coming in the opposite direction just in the middle of a tunnel or a bridge. American railway bridges are remarkable for their narrowness. Very often the sleepers themselves project into space, and never is there any track beyond them. 
"You said it, brother," he replied, "dozens of 'em." "And what's more, there's a couple of long tunnels just a mile away-look, you can see the beginningand beyond them there's a bridge pretty nigh half a mile long-and trains is mighty funny things to play hide and seek with, y' know!"

I was of that opinion myself. As I looked, I saw a train emerge from the tunnel ahead. I reflected that I should have been just about there by now if I hadn't stopped. I went back to Wheeling.

The next day I covered twenty miles in four hours and found myself back in Wheeling again, but this time by another road. Nothing daunted, I said nothing, clenched my teeth, and polished off another twenty until dark.

The day after I did better. The nett progress at the end of the day's work was twenty-five miles instead of twenty. I arrived at the conclusion that Missouri had one great advantage that I had hitherto overlooked. It was an excellent place to get out of !

On the next day I covered five miles in six hours, and although only forty miles or so from Kansas City, which marks the commencement of the historic Santa Fé Trail leading to the Pacific Coast, I made a solemn vow that I would "ship" everything there by train at the next town. The next town happened to be "Excelsior Springs," twenty miles further on. The road improved considerably, and the comforting thought of civilization at so short a distance urged me on and I broke that solemn vow. I rode into Kansas City late that afternoon, a mass of bruises from head to foot, just as the speedometer showed 1,919 miles from New York. I ferreted out the Henderson agent and left Lizzie in his tender keeping. 


\section{CHAPTER X}

\section{RESULTS OF A BREAKDOWN}

It took three days for me to find that the Kansas City I was in was not the Kansas City I thought I was in. I took it for granted that Kansas City would be in Kansas State. But it was not. My Kansas City was in Missouri, but after searching diligently at the post office for mail that wasn't there, I found there was another Kansas City on the other bank of the river. All good citizens of Kansas City, Mo., turn up their noses at the mention of Kansas City, Kan.,_-" no connection with the firm opposite" sort of thing.

Of the two, Kansas City, Mo., is by far the more commendable town. It hustles and bustles just as every good American city should do. It is exactly " one hundred per cent American." The advertisements in the papers said so. I believe it, because any city that boasts of being four times larger than it really is must be 100 per cent. American! But I must give Kansas City its due. It represents the essence of keenness and enterprise in business and farming circles. It has that "breezy" air that is so healthy in city life, compared with the dull, gloomy inertness so characteristic of most manufacturing towns, especially here in England. Kansas City has some excellent streets and some magnificent buildings, and has undoubtedly grown at a remarkable rate during the last ten years. Being the last city of really large 
dimensions that one meets until the Pacific Coast is reached, it is the connecting link between the East and the Far West. Grain and farm produce from the vast States of the West flow unceasingly through its warehouses and stockyards. A network of railways concentrates to a focus at Kansas City, railways bringing in and taking out millions of tons of produce annually.

The next day, when I visited the motor-cycle agency, Lizzie was standing disconsolately where I had left her the day before. I begged, entreated, exhorted, and threatened that she be given immediate attention. I lied abominably to the manager that $I$ was putting up a record between the coasts and every minute was important.

How could I expect to beat all existing records if they kept my machine in dock for a week ? I was promised that it would be started on "right now." That term "right now" has a significance unknown to Europeans. It is subtle and evasive, intangible and incomprehensible. It conveys a sense of such utter obligation on the part of the speaker that one has not the heart to query its exact purport. As far as I can ascertain, or at any rate as far as I have experienced its application, it is more similar to the French "tout de suite" than any other expression I can identify, in that it might imply anything between the immediate present and the indefinite future.

Lizzie required several replacements, including a new set of bearings, a cylinder and two gudgeon pins, these latter being broken in half at the middle. The agent told me that they always were liable to break. If they were put in upside-down, as he always fitted them, so that the oil hole was at the bottom instead of the top, they would not break at all. Further he hinted that my 
particular machine was turned out while a good fat strike was in progress at the factory.

"Well, you can stick it together so that it will take me to the coast all right?" I queried anxiously.

"Well, yes, I guess I can," was his studied reply.

"Go right ahead then, boss, but do it quick! I'm running short of money and can't afford to stay in your metropolis right here for the benefit of my health."

Being destined then to remain in Kansas City for four or five days more, I found myself with ample leisure in which to collect my thoughts and prepare for the journey through the "wild west" ahead.

One result of my leisure was that I paid a visit to the editor of the Kansas City Star. This is one of the most progressive newspapers in the United States, and circulates everywhere in the West. The extent of its circulation and the results of its progressiveness I was, however, still to learn.

The editor was found as usual at his desk in the middle of a large room, surrounded by his myrmidons in typical American style. He greeted me with extreme cordiality. "No need to tell you I'm English, I suppose?" I said.

"See that door over there?" (pointing to the one in the far distance through which I had entered). "Well, I spotted you were an Englishman the minute you came in there."

I explained with complete humiliation that I was travelling across the United States of America on a motor-cycle and wondered, whether his readers would be interested in the point of view of such a despicable object as an English motor cyclist on this great and wonderful country. "Not for the love of the thing, you know," I added, "I 
don't see why I shouldn't earn a dollar or two on the wayside."

He pointed to a typewriter standing idle at a desk. "Let's have the story right now, and give us something about roads. There's a big movement just started to get good roads, so you can just hand out the straight dope to everybody on the subject. Get me? Something good and snappy."

I explained that while no one was more eminently capable of writing about American roads than myself, I had never graduated as a typist in the course of my business career. I should, therefore, have to retire and push the modest pen.

"What! a business man who can't use a typewriter? I didn't know there was such a thing," was his rejoinder. I let them have it about roads. I referred also to their commendable system of arresting road-hogs. This with a few pro-American embellishments such as "wonderful country," "indescribable beauty," "inexhaustible wealth," etc. etc., rounded off the theme.

My friend the editor not only rewarded me at the noble rate of a dime a line $(5 d$.$) , thus assuring the hotel expenses$ for my stay in the city, but also gave me about an hour of his valuable time in talking about almost everything under the sun-mainly American. It is rather surprising to an Englishman to find that practically any worthy American business man, no matter how busy he may be or how valuable the time lost thereby, will entertain a visitor for an incredible length of time. If the visitor happens to be an Englishman, he is all the more pleased to do so because then he can talk uninterruptedly about America and what a wonderful country it is. All the noted men of Europe, I learned, had been in the office and sat 
in that same chair. The editor told me so. Lord Northcliffe spent all his leisure hours there while in the States. So also did many other notorieties, some unknown to me. Leastways, so the editor told me. I took his money and bade him farewell. 


\section{CHAPTER XI}

\section{THE SANTA FE TRAIL}

On the fifth day after my arrival in Kansas City all was in readiness for my departure. There was another big bill to meet for Lizzie's overhaul, but I had the satisfaction of knowing that the bearings had all been replaced, as well as a few cylinders and pistons and things, and that there was just a chance of getting to the coast before something else went wrong. Once again I wrote polite letters to the factory at Chicago, paid many dozen "green backs" over the counter, and started off once more, this time with only thirty-five dollars in pocket. Once again fate and the post office had been unkind. Not a suggestion of anything was there at either of the post offices at any of my calls thereon. Amid vague wonderings and oft repeated doubts I promised myself a big cheque at Santa Fé, next stop. I was just beginning to know the ins and outs of the postal service.

The Santa Fé Trail is the oldest and most interesting highway in America. Rather should it be said that the pioneers over what later became known as the Santa Fé Trail were the first to leave permanent marks on routes that have since become "highways" between the Central-Western and the Far-Western States. In the days of the ox team and prairie-schooner, the plains and mountains were crossed by trails, usually along the lines of least resistance, keeping as close as possible to bases of supplies 
and water. Travel over the Santa Fé Trail began about 1822, starting from Little Rock, Arkansas (pronounced Arkansaw), and following the Arkansas River west. A few years later, this trail was superseded by a more permanent one going west from Kansas City (then called Westport) to " Great Bend," a base situated, as its name implies, on a great bend of the Arkansas River, and thence to Santa Fé by a choice of two routes. An important trade with the Spanish population of the south-west was early developed, reaching its zenith in the '60s. This route, the one which I followed, has now been marked a considerable part of the way by stone monuments erected by the "Daughters of the American Revolution" and constituted the chief inroad from the East to the Far West. Santa Fé itself, next to St. Augustine, Florida, is the most ancient city in America, having been founded in 1605 by Spanish settlers on the site of a "pueblo" or Indian village of far-distant origin. Naturally, therefore, it was the centre of trade for years numbered by hundreds, and traders from afar brought their goods and supplies in boats up the rivers as far as navigable and then in teams across the dreary plains and over the steep Rockies to this one destination.

Later, in the gold-rush to California in 1849, emigrants reached San Francisco, the "Golden Gate," via this same Santa Fé Trail, undergoing indescribable hardships on the way, and at all times subjected to frequent onslaughts by the hostile Indians.

The first railroads were built across the plains alongside the old trails. The first automobile trips (and I take off my hat to them !) naturally followed the railroads, from the necessity of keeping near to supplies. But the motor-car of to-day frequently makes either short cuts or detours- 
leading perhaps 100 or 200 miles away from the railroadin order to visit sections offering unusual attractions, or places of historical interest, even when located in desert regions.

Thus, with Kansas City behind me, the journey begins to be really interesting from an historic, if not from a scenic point of view. The hand of modern civilization at last is seen to relax its grasp. Now, instead of the prosaic, the conventional and the luxurious, are we to find the unique, the heterodox and the primitive. After the tainted breath of huge cities and the seething, crushing, maddening turmoil of wealth and modernism are to follow the pure unbounded atmosphere of the giant plains, the mystic call of the great mountains, the vastness, the fearfulness and the rapture of the scorching deserts. Which shall it be for me?

Before me lie 500 miles of perfectly flat and uninteresting country before I leave the State of Kansas and enter Colorado. Then follow another 200 equally flat, equally drear, to be crossed before the Rockies loom into sight. Seven hundred miles of endless weary prairie, stretching always, everywhere, as far as the eye can see, with never a hill nor a dale nor hardly a tree in sight !-Nothing but boundless, illimitable corn, wheat and prairie.

That night, after an afternoon's run of 120 miles, I rested in a cornfield. The road had ended abruptly. An old bridge had been demolished and a new one was about to be erected. A heap of debris in the middle attracted my attention, and I was fortunate. Here the road ended; there was a little chasm some thirty feet across; beyond was the road again. Nothing for it but to turn back. Turning back is always objectionable. I deemed that it would be less so in the morning. That is why I wrapped 
myself in my mosquito net behind a hedge in a cornfield and offered up thanksgiving.

The mosquito net-I have not mentioned it before! I purchased three yards of it in a little store back in Missouri while waiting for the road to dry up. I also bought a cap. Having worn no headgear since leaving New York, I soon discarded the cap and later gave it away to a little urchin who looked as though he needed one more than I. But the mosquito net remained for a longer spell. Nightly was it unfolded and wrapped around my unworthy self, and daily was it folded carefully up again and packed into the bag once more.

I shall never forget that mosquito net. It was white. Leastways it was when I bought it. I tried countless ways of enveloping myself in its folds, but never with any great measure of success. The tout ensemble when struggles had subsided, with self in pyjamas surrounded by wrappings of white chiffon on a black background (my waterproof groundsheet) must have presented an extraordinary spectacle to the poor birds above. No doubt they mistook me for some miscreant angel served with an ejectment order without notice from the star-lit sky ! At first all went well. I breathed the calm midnight air unmolested. "It can't be true," I told myself, "there is a catch in it somewhere." There was. I discovered that whereas it was comparatively difficult for a mosquito to get inside the net, once he did get inside it was an utter impossibility to get him out again. One mosquito inside a mosquito net is worth much more than two outside. He is worth at least forty!

Then I tried various stunts because, when I did get properly wrapped up, I invariably rolled out of it in my sleep. I rigged up poles and sticks and cut little pegs 
from twigs to hold the net down like a tent. I had it stitched up the sides like a bag and wriggled into it nightly, only to find it wrapped around my feet in the morning and my face and arms a mass of bites. Finally, in the heart of the Rockies I think it was, I gave it up as a bad job and resorted to the Citronella method once again. For aught I know that old mosquito-net is still hanging to the fence of a cow-ranch at the foot of Pike's Peak, Colo.!

Up at dawn in the morning and away. I found another road some three miles back and continued on my way westward rejoicing. Sixty miles were covered before breakfast. The towns and villages became very few and far between, and Council Grove, where I enjoyed my morning repast, was practically the first town to be encountered. I had set my mind on a good day's run and prayed for good roads. On my map, which was said to be the only road-map of the United States published, and was hopelessly inaccurate and inadequate, there was a huge river, the Arkansas, a couple of hundred miles ahead. I judged it to be about half a mile wide. Verily, thought I, the Arkansas River shall be my resting place to-night, and Great Bend my destination.

After a long day's ride I toiled into Great Bend at sunset. The journey had been monotonous and the road fatiguing. I longed to stretch my weary bones on the banks of yon mighty river and bathe in its refreshing waters. While I was devouring my evening meal, on a little high stool in the one and only café of Great Bend, I was consoling myself with this prospect.

Outside, a little group of men were sitting on the pavement eyeing Lizzie propped up against the kerb. It is the general thing to sit on pavements in the Far West. 
They are much higher than those we are accustomed to and afford adequate and comfortable accommodation for the weary population. Often one can see a row of men sitting on the kerb for the whole length of a "block" when the sun is in such a direction that the sitters are sheltered by the buildings behind them. I made a mental note : "Another good idea for importation to England." I pictured tired Londoners sitting down in rows on the pavements of the Strand or clustered leisurely around Piccadilly Circus chewing "shag"!

My pockets bulged with bottles of "Buckeye," an imitation root beer sold extensively in the States (since prohibition) and alleged to have a "kick" in it. A suspicious swelling elsewhere on my person indicated a tin of pineapple chunks (a delight of my youth).

"Goin' far?" inquired one of my scrutineers.

"Down to the river to-night. This the right road?"

"Right slick in front of your nose half a mile away."

I came to a long wooden bridge arrangement, but could find no river. After going two or three miles and finding no Arkansas, I returned to Great Bend to try another road. This time I inquired at the café.

"Straight ahead, you can't miss the bridge."

"Oh, is there a river there? I didn't see one."

Back again to the bridge, but no signs of a river. Instead there was a great stretch of white sand like a seabeach, but with little trees and shrubs and tufts of grass dotted here and there.

"Well, this is no Arkansas River," said I to myself, "but I'm through. This sand looks pretty comfortable, so here goes."

In amongst the sand dunes I made my bed and never did traveller camp in more delightful surroundings or rest 
in more peaceful conditions. The stars shone out with unusual brilliancy in the heavens, and the moon rose at the setting of the sun, enveloping all in a magic sheen of silver. A soft cool breeze played gently over the plain and little birds of unknown song and uncounted variety slowly sang themselves to rest. This indeed was no night for sleep ; more was it a time for quiet contemplation of all the things that make life good and noble and worthy of the living. How terrible, how awful it would be when I should in the end return to the narrow beaten track of city life, and once again be fettered to "the trivial round, the common task" that knows no magic spell and thrills with no mystic breath. Could it ever be that the duties that bind and numb, the needs that hamper and clog, the tasks that chill and estrange, should once again enshroud me in their toils? Such I suppose are the meditations of everyone who breaks away from home to enjoy for a spell the bounties of nature and whose canopy is the sky.

In the morning I awoke as fresh as the merry sandpipers and waterwagtails that ran and hopped about in dozens. There was no trace of fatigue, no thought but of the glorious day that was opening, no regret but that every day had not brought and would not bring this rapturous dawn.

I learned in the village that $I$ had indeed slept in the middle of the Arkansas River! The summer had been excessively dry and that part of the river which, several hundred miles away, had risen boisterously in the heart of the Rockies and had not been dried up with the heat, had drained through the sandy bed, never to emerge again. This though was one of many rivers that I was to meet with no water in them. Sometimes even, I was to 
see fences and railways erected across would-be rivers to prevent the cattle straying!

The farther westward I travelled the fewer became the towns. Nevertheless, albeit they were sometimes thirty and forty miles apart, they were all prosperous, new and inviting. Of gasoline there was always an abundant supply at 22 cents (11d.) per gallon. Of garages there were enough and to spare. Indeed, it was surprising what palatial garages were to be found everywhere. Outside each was the familiar "Bowser" pump communicating with a 1,000-gallon tank below the pavement from which anything from half a gallon to six gallons at a time could be pumped up by the garage hand at one turn of the handle. A flexible pipe with a cock at the end leads from the pump, and one's tank can be filled in a few seconds without a drop being spilt. Not once in all my travel through the States have I seen a petrol tin. I do not believe they are used at all because nowhere in the States is it necessary to travel by road with spare petrol on board, provided, of course, that one is careful to fill up regularly at the different towns or stations on the way. Even in the heart of New Mexico and Arizona, even in the terrible "Death Valley" and Mohave Desert of California, stations are found where "gas" and oil can be bought in plenty to carry one well beyond the next to be reached. At Larned I made a hearty breakfast from canteloupe, coffee and "pie." Now "pie" is one hundred per cent. symbolical of America. In the States they have attained the absolute limit of perfection in the manufacture of pies; indeed I think it must be a "key" industry. Not only can pies of every conceivable kind of fruit (and many inconceivable ones) be obtained, but the cooking thereof is perfection itself. 
On the road again, ever westward, ever looking forward to the day when from the dreadful monotony of the plains the Rocky Mountains would loom high and faint upon the horizon.

I passed a few small towns at long intervals, towns with picturesque names such as "Cimarron," "Garden City," "Lamar," and "Las Animas." In every case an approaching town was heralded by an unspeakable stretch of road. With the passage of traffic of all kinds the road was ground up into powder. Every inch of it was loose sand, sometimes a couple or three feet deep, sand that would be impassable to any but horse-drawn traffic. As a saving grace it was generally less deep at the edges of the road than in the middle, and locomotion was just within the range of possibility with frequent assistance by way of "leg-work" and with occasional spills and crashes. The only use I had for these towns lay in the unlimited scope for ice-cream consumption which they all afforded. As time went on, Lizzie showed signs of further disrupture. Gradually little noises and rattles developed and slowly her power fell off by almost imperceptible degrees. Of course I had ample power even at that to cover the country, which, with few exceptions, was level, and the road, where dry, was good. I averaged no more than twenty-five, and as there was hardly any stop to make or traffic to slow down for, this did not mean travelling more than thirty at any time. A good conscientious motorist, I told myself, would stop and examine everything. I had got far beyond that stage. "Let the old crock go on till she busts," I muttered inwardly and opened up to avoid an oncoming thunderstorm.

Thunderstorms travel quickly in U.S.A. They get a hustle on and don't mess about generally. There's never 
any doubt about it when you see one coming. It means business ; there is none of that burbling, gurgling, gloomy overture that hangs around for hours in England and very often comes to nothing at all. No, no. In U.S.A. you see a thundercloud on the horizon and before you've got "George Washington" off your lips it's on you with a crack and a bump and a splash and woe betide any innocent motor-cyclist who is riding in his shirt-sleeves with his jacket strapped on the back.

But that rain was good! Kansas can be hot when it likes and it's mostly liking all the time, so that a showerbath is a gift from the gods. When it stopped, and fortunately before it had had time to do its foul work on the surface of the dirt road, I arrived in Syracuse, a small town with not much of a population to substantiate its artistic name, and but twenty or thirty miles from the Colorado State Line. Net result 150 odd miles that day and to-morrow with luck I should behold the Rockies. Oh, those Rockies! How I longed to see them!

The rest of the evening I spent adjusting Lizzie's tappets (they had all worked loose, hence the noise) and eating pies and ices at every café in the place. The night was spent in a dirty inhospitable little inn calling itself, I think, the Broadway Temperance Hotel. Heaven help Broadway, and the Devil take all temperance hotels! I shivered as I compared this with the night before.

Westward once more. In an hour I crossed the State Line. Invariably there is a large sign-board denoting this fact. "This is the State of Colorado, the most Picturesque and Fertile State in the Union," it read on this occasion. This time there was not such a marked change in the country. It was still flat, still dismally uninteresting. Everything looked dried up. 


\section{ACROSS AMERICA BY MOTOR-CYCLE}

At times the trail, which hitherto had followed the Arkansas "River," crossed and recrossed it by long low creaky wooden bridges. There was still no water flowing underneath them. "Water? That was only meant to flow under bridges," says the confirmed toper. The Arkansas River "puts him wise" on that point!

Flagrant mistakes now appeared on the map. Roads and towns which in reality lay on one side of the river were alleged to be on the other. Distances became either grossly exaggerated or hopelessly underestimated, so much so that I only expected to get to a place when I found myself already there. If it turned out to be another place than that I had expected-well, there, that made it all the more exciting.

Later on the trail became very dishevelled and forlorn. Great waves of sand were piled up in ridges and furrows defying all comers. Sometimes a benevolent signpost advised all drivers of automobiles not to risk travelling thereon, but to follow such and such a detour which would lead back to the road ten or fifteen miles farther on. I saw many such notices. At first I scorned them, but the sand grew so thick and deep that it enveloped the frame of the machine and the projecting footboards brought progress to a standstill. For several hours I pushed and heaved and skidded and floundered about on highways and detours and pathways that baffle description. If I averaged ten miles an hour I was content with that. I got through many places that passing pedestrians swore were impassable. In short I was beginning to reduce locomotion over American roads to a science.

At La Junta, the Santa Fé Trail swerves to the southwest towards New Mexico, but another trail continues westward and northward towards Pueblo, Colorado Springs, 
and Denver, the three "cities" of Colorado State, and Pike's Peak, one of the highest points of the Rockies. I decided to leave the trail for a day or two and go sightseeing in famous Colorado. So I continued westward, scanning the horizon all the time for a vision of a vast and rugged mountain range. The sight of mountains would be as balm to a sore wound; as welcome as a spring of water in the desert; or even as the sight of land to a shipwrecked mariner, so heartily tired was I of the endless plains and the inexhaustible flatness and monotony of the country for the past thousand miles.

Instead of mountains came a cloud. Soon the whole horizon was black. I knew what that meant. It meant "laying up" for a day or two and looking round for a good place to lay up at "right slick." But I was in the midst of nowhere. Not a house or a shack could be seen anywhere. Even as I scanned the country the rain came. The road was not sandy enough for it to soak through. Instead it absorbed it greedily and changed to mud. I rode as far as riding was practicable and then $I$ pushed. In a few miles I came to a little wooden shack at the side of the road near a large dyke already swollen with rain. The shack looked as though it had recently been thrown together with matchboarding and liberal use had been made of tarpaulins as curtains instead of doors. I left Lizzie in the road and went to explore. 


\section{CHAPTER XII}

\section{THE ROYAL GORGE OF ARKANSAS}

There were two huts. I drew aside the tarpaulin and peered in one of them. It was stuffy and dark and filled with beds, tables, cupboards and piles of odd furniture and miscellaneous clothing, boots, blankets and mattresses. In a clearing amongst the general debris sat a middle-aged woman on the top of a trunk before a sewing machine.

"Hope I'm not intruding, but is there anywhere I can get out of the rain until it goes off ?"

From a heap of assorted oddments under my very nose came a voice, a man's voice.

"Sure ; come right in, brother. You're welcome to any shelter we can give you. Guess you've gotten a little wet out there? Jim, go you into the kitchen and bring a chair for this gentleman."

A pile of musty books rocked on its foundations in another corner and a young lad of fifteen or sixteen rose as if from out of the earth.

We talked for an hour, but the storm showed no signs of abating. The wind whistled through the tarpaulin doorway and gloomy blobs of water dropped from the ceiling from time to time on all and sundry.

Strange to say I did not betray my nationality. I presume that by that time I had unconsciously acquired in a small degree the language of the race.

"You're from the East, I suppose?" queried mine 


\section{THE ROYAL GORGE OF ARKANSAS 107}

hostess after half an hour, the first words I had heard her speak.

" Oh, sure, I'm from the East, the far East-in fact, the vERY Far East!" I replied.

"Boston?"

"You've said it," was my rejoinder. "Ever been to Boston ?" I added.

"Yep, I was there I reckon fifteen fall. All I remember now was the railway depot. What do they call it, the South Union?"

"Sure, it's the South Union all right. Why, I was born only a couple of blocks from the South Union depot."

Miserable liar that I am, I have never been in Boston in my life.

"Fine city, Boston," interjected the male voice from below.

"The finest in the world, sir," I effused.

Meanwhile the rain continued, with not the slightest sign of abating.

"You best bring your motor-sickle under shelter and stay the night right here," suggested the man of the house when the shadows deepened and still the rain went on.

"I'm sure that's very good of you, sir, but I'm afraid I'd better not trouble you any more."

"No trouble at all; we're delighted to have you ; we can soon make a bed up with a few chairs and some of these blankets."

I was only too pleased to avail myself of their hospitality and agreed.

At supper I had a chance of studying the various members of the family. Apart from the man and his wife, there were two boys, and quite a few more people rolled 
in afterwards from a source unknown to me. Supper consisted of stewed beans, with plenty of bread and water, and more beans.

That night I slept on four chairs in a row near the door. The two boys were elsewhere in the gloomy darkness within. All through the night I waged war upon mosquitoes and slapped myself vigorously for many hours until the guerrilla warfare grew so tiring that sleep overcame its anxiety. The mosquitoes then nibbled my face to their hearts' content-if they have hearts, which is doubtful.

In the morning breakfast consisted of stewed beans with plenty of bread and water, and more beans.

By lunch-time it was still raining, but slower. I stayed to lunch. It consisted of stewed beans, with plenty of bread and water, and lots more beans.

In the afternoon the sky cleared, the sun opened his eyes with a snap and began his work of drying up the roads. Throughout the day I had employed my time with giving Lizzie an overhaul. I had the cylinders off, examined the bearings, and tightened things generally. Meanwhile I discovered that my friends were building a house on an adjoining field. They were doing the work alone, with the help of a few friends, who no doubt accounted for the other partakers of stewed beans. A pile of timber lay in one corner of the field and the foundations had already been laid and the uprights erected.

It was well seen that the house was for themselves to live in. Never have I seen a house grow so quickly or watched the progress of one so keenly. Moreover the walls were not all out of the vertical or the windows far from square as one generally gets in home-made houses (and very often other kinds too !) 
"You'd better stay and have something to eat, brother," said mine host as I was strapping my bag on Lizzie's back in preparation to depart. "We've only got stewed beans, but they're a mighty wholesome food."

But I had visions of apricot pie in Pueblo, thirty miles ahead, and urged my desire to be getting on the road " right now" while the weather lasted.

They were good folks, those house-builders of Nepesta. Not a cent would they accept under any circumstances for their hospitality to me. They worked hard and feared God, and every time they partook of their frugal meals grace was said beforehand and afterwards as well, in thanksgiving for the blessings that rewarded their toils. One could not refrain from comparing the civilization of the West with the sordid life-scramble of the East.

Once on the road again the despondent sort of gloom that seemed to surround everything became a thing of the past, as gradually the Rockies loomed up on the horizon; at first faint and mysterious they gradually deepened in colour and sharpened in outline. What a refreshing and soul-inspiring sight after nearly 1,000 miles of travel across the dusty, dreary, tiring plains !

In the late afternoon a thin cloud of curling black smoke was seen upon the horizon. This is invariably the forerunner of a western town. Long before one actually draws near to one's destination, if that destination be a town, it is discernible sometimes twenty and even thirty miles away by the tufts and clouds of smoke that hang over it. The sight is as that of a huge Atlantic liner no more than a fraction above the horizon. One cannot discern its hidden size or form, but the smoke from its funnels threads upwards into the heavens like a sentinel in the engulfing vastness of the sea. 
Thus does one approach a town set in the heart of a bewildering plain. Gradually it is possible to discern here and there a chimney-stack and sometimes the reflection of a solitary window in one of the tallest buildings will scintillate on the distant horizon.

The busy town of Pueblo drew nigh. With a rapidly increasing population of over 50,000 and nearly 300 factories, some of which are among the largest steel-manufacturing plants in the States, Pueblo is known as the " Pittsburgh of the West." But let not the reader be misled by this title into thinking that Pueblo is miserable and gloomy and odoriferous as is the wont of most towns of its character. Its streets are wide, clean and well-lit with electric lamps; its buildings also are clean and of comely architecture; there are no slums or povertystricken quarters, and with the giant mountains looming in the distance Pueblo is an ideal manufacturing town in ideal surroundings, besides being the centre of a rich mining district.

From Pueblo, after ministering to the wants of the inner man, I turned again westward towards Canyon City, some forty miles away in the heart of the Colorado Rockies, in order to visit the famous Royal Gorge, known also as the "Grand Canyon of the Arkansas," thence to return by a large detour through Colorado Springs, another western city like Pueblo, and with perchance a side-trip up the automobile road that has been cut to the summit of Pike's Peak (the highest highway in the world), to return to the trail to the south into New Mexico.

That rise from Pueblo into the Rockies will linger ever in my memory. Surrounded in all directions but behind with glowering mountain ranges, the road cut across vast rolling plains and prairies that spoke of desolation 


\section{THE ROYAL GORGE OF ARKANSAS 111}

immense and wonderful. As the sun set behind the mountains they became tinged and fired with every shade of colour, and darkness slowly crept through the valleys and filled the air with vague wonder and glorious contentment. In front and slightly to the right rose Pike's Peak high above its fellows, thrusting its massive splendour 14,000 feet and more into the ruddy heavens. An eerie feeling of intense loneliness crept through my veins as mile after mile was passed through naked prairie in the midst of such awful surroundings, with never a soul to be seen. I travelled thirty miles before the chilly breezes and the growing darkness constrained me to stop. (The headlight was hors de combat; only the "dimmer" would work.) In all that distance I saw no living thing save the tufted grass and the black pine-trees peppered over the sides of the foothills.

When progress was no longer possible, I pulled Lizzie to the side of the dusty road, propped up her stand, and unfolded my blanket on the grass of the prairie at her side. Once again I should enjoy the sweet luxury of Nature's bedchamber in the heart of Nature's best.

But Dame Nature's bedchamber is oft a chilly and inhospitable one, and despite the invitations she tenders to all who count themselves her lovers. "Bring your own blankets" is the one stipulation. She will provide the rest. She will bring the magic sleep, the fairy dreams, the golden dawn and the thrills of ecstasy as one wakes again fresh and strong into her lovely world of health and beauty.

From rolling plains we passed to bounding foothills where the road twisted and turned and crossed torrential streams, spanned by picturesque stone bridges, until the delightful little town of Florence was reached. Here 
came a short stop for breakfast and thence on again towards Canyon City.

From Canyon City to the Royal Gorge has been built a wonderful piece of road, winding and climbing into the very heart of Colorado's rugged bosom. The gradient in places is terrific. Every ounce of power was sometimes necessary to surmount certain stretches, and blind S-bends carved from the solid face of the rocks made travelling a danger as well as a test of skill. At every bend and every turn some new panorama would spring to view and farther and farther away would fade the distant horizon of the east. Whither the road led was impossible to see. Frowning cliffs and wooded crags seemed to be the only goal ahead. After half an hour of heavy toil we reach an opening. There is a turn to the left, a flat plateau and a slight dip down; the trail dies away to nothing and a sign "Royal Gorge" is announced from a bungalow near its end. The gaunt pine-trees also end, there is a huge gap in the earth and the plateau beyond is seen a clear half-mile to the westward. We clamber over the rocks and boulders, carefully and gently, where the ground has suddenly stopped, and peering down from the brink we gaze upon a tremendous cleft in the crust of the earth. Some 3,000 feet below we see a raging torrent like a huge white snake lashing with a sullen roar along its tortuous path, hemmed in by vertical walls of cold relentless granite. The rushing torrent is the Arkansas, a mighty flood although but a few miles from its source, and the same river whose bed 700 miles away towards its mouth had afforded such excellent nocturnal accommodation a week before !

It is as though one is peering into the very bowels of the earth. That this gigantic chasm has been cut out 
by that river which now is over half a mile below seems almost incredible. As we gaze there is another surprise in store. Like a tiny plaything, a train emerges from a bend in the cliffs and with little infantile puffs of smoke crawls along the rails which one now sees running along the narrow river bank. Clinging close to every twist and turn the train proceeds. There is scarcely sufficient space between the rugged walls and the surging river for the single track. At one point the width of the ledge is but 10 yards and the track has been built out over the water. The river dashes madly through; the engine sways from side to side as it drags its heavy load onward. Down there, it is said that the sky above is but a thread of light and the stars can be seen at midday as in a mine.

One moves one's gaze and scans the rugged boulders that lie heaped and stacked and strewn about as if but a push would suffice to send them hurtling down into the chasm below. Here and there are stunted growths of sage, cactus and priekly pear, or a giant fir-tree springs from a grassy cleft in the rocks.

Retracing the trail, we find ourselves soon descending the precipitous winds and turns that lead back to Canyon City. On the left we pass "The Famous Sky-line Drive," which announces itself by placards here and there as "The greatest scenic highway wonder of the world." But a little distance from here is also "the one-day trip that bankrupts the English language" and such beauty spots as are suggested by the names "Hell Gate," "The Frying Pan," "Roaring Fork," "The Devil's Thousand-Foot Slide," "Cripple Creek," "The Garden of the Gods," and other similarly euphonious and onomatopœic appellations.

It would be tempting to explore all these places and to see more of Colorado and the immense fund of natural 
beauty which she displays in endless variety. But impatience draws me again towards Pueblo, so that I can once again strike the trail that leads to California. I am already getting anxious to see the blue sea, though yet only half-way between the oceans!

That afternoon as I paused beneath a "bowser" in Pueblo while Lizzie was filled to the brim, I inquired the condition of the road to Trinidad, some 100 miles to the south on the Santa Fé Trail.

"Trinidad? The worst road in America, sir !-absol-oot-ly the worst road in America, sir."

The prospect was not pleasing. There was certainly an element of interest about it because it would be fascinating almost to see for oneself exactly what Americans did consider a bad road. My formula so far had been that when an American said a road was good, it was bad. When he said it was bad, it was damn bad! But what would the "worst" be like?

As I sped along, the sky deepened and a severe thundershower threatened. Heavy black clouds glowered around the mountain-tops and every moment I expected a sudden outburst from the heavens. On my right the Rockies rose higher and higher. In the distance, but gradually approaching, rose Blanca Peak, a dreadful, ponderous giant amongst its brethren, its gloomy crest piercing the very vaults of the sky and hardly visible in the sombre blackness that so often hangs in the neighbourhood of these western mountain peaks. Now and again a streak of lightning would flash through the heavens, and the dull thud that followed, belated and awe-inspiring, would rumble backwards and forwards along the valleys, reverberating from peak to peak until finally it was lost in the depths of the firmament. 
On the left spread the rolling plains as far as the eye could reach, like as the sea stretches up to the shores of Dover whence the cliffs rise sheer and stubborn. In front lay the road, skirting the borderline twixt plains and peaks.

I soon came to the conclusion that that garage hand in Pueblo had been "pulling one over me." The road was just splendid. Laid in hard flat well-made macadam, its surface was excellent, passing all understanding. As I sped on ever quicker to avoid the gathering storm, the non-skid pads of the tyres hummed a merry tune. Could I be on the right road? I asked myself once again. I must be, for in these parts there is only one road to be taken. No others exist. There must be a catch in it somewhere, I told myself.

An hour went by and still the thunder rushed around Blanca Peak the Mighty, now receding from view. An occasional shower just on the edge of the storm would hasten me on my way. Still the road was perfection itself, and still it fringed the chain of minor peaks that runs from north to south, the boundary of the vast plateau of over 1,000,000 square miles that includes, in those unassuming words, "The Rockies." Another hour flew by.

And then it came, like a thief in the night, sudden and unexpected. The smooth grey macadam vanished, as though the magic wand had ceased its power. Instead lay ahead a villainous track in the dark brown soil of the prairie, a track beaten with sorrow and stricken with grief, here battered into ugly patches, there heaped into fearful ridges and seething masses of mud and rock. It had rained. Those words alone express a world of sin and shame, when one speaks of a trail " out West." Here 
once more were the old agonies, the old discomforts, the old tortures, the old haulings, heavings, pushings, joltings and bruisings. The sky again became overcast. The rain began to fall tormentingly. I had still twenty-five miles to go to the nearest town. The sun sank lower behind the mountain ridge. The rain fell faster ; if I did not reach Walsenburg that night I should have to rest among the prairie-dogs in the pelting rain. And what chance was there of reaching Walsenburg before dark with no lights and at an average of six miles an hour "all out," with only a paltry hour before dusk?

I will not attempt to describe that ride. I feel it should not be described. "The ride that bankrupts the English language," indeed, thought I. Many times I left the road altogether and pursued my course whither I listed over the rough prairie. Strewn with boulders, rocks and ugly stones, carved here and there in fantastic shapes, with mysterious hollows and quaint prairie-dog holes, it was just possible to scramble along. From a distance the " road "I had left looked better and I returned to it, only to find that the prairie still looked more enticing. How I leapt over the smaller stones and skipped round the larger ones always intent on nothing but the few yards that were to follow, I shall never completely remember. Again and again I returned to the road and endured its agony for a spell, and again I swerved away from it, my every bone shaking in its joints and my teeth rocking in their sockets with the vibration.

Let me forget. These things are not good to gloat upon! I remember but one amusing incident, which was but the forerunner of many more to come. I had returned to the road for a spell. I came to a slight dip. It was like a lake full of fluid mud where a wayward stream 
had swollen with the rains and encroached upon the sanctity of the road. "Not negotiable" was the unspoken verdict. Strange to say, the prairie was now fenced off from the road boundary, so there was no avoiding the coming struggle. "It's got to be done, so here goes"; slowly I dived into the yellow mass. Just half-way the back wheel turned to jelly and seemed to crumple up to nothing. With one big splosh the whole five hundredweight of us flopped gaily over into the mire. Pinned down by the weight of the machine, the mud had ample time to soak through all my clothing, into my pockets and down my neck. Lizzie's submersion would have been entire instead of partial had I not intervened.... After a short struggle I ultimately succeeded in extricating my right foot from between the brake-pedal and the engine, and heaved the bulky mass from its repose. No sooner was this done than we slithered once more and fell over en bloc on the opposite side.

$\mathrm{Oh}$, the joys of motor-cycling in Yankeeland!

I did get to Walsenburg that night. As luck would have it, the two hotels were full. At least the deskclerks avowed by the bones of their saintly grandmothers that there wasn't a room left. Probably they were moved to anxiety lest their worthy name should be soiled by this mud-covered intruder!

I found a room after a long search at a fifth-rate " dosshouse" devoid of furniture, where the landlady demanded my money in advance before giving me the key to my room.

Thus passed another day. 


\section{CHAPTER XIII}

\section{IN SOUTHERN COLORADO}

There is only one road in the States as bad as that from Walsenburg to Trinidad. I refer to the road from Trinidad to Walsenburg.

In spite of that it was a good road; I got through. It took endless patience, perseverance and a morning of time to do those fifty weary miles. The scenery was strange, almost to the point of weirdness. From the surrounding flatness would rise sudden plateaus, with dead vertical sides and perfectly flat tops. Even the hills and mountains where they occurred (save in the distant Rockies) were modelled on the same plan, rising abruptly from the plain and ascending in two, three or more sudden steps. The effect was just as though the land architecture had been entrusted to some aspiring cubist or futurist instead of to the well-disciplined laws of Nature.

I do not profess to have attained much learning in the science of geology, and speak, therefore, as one without authority. But it seemed to me on many occasions that to study the geology of the Far West, the English scientist would have to forget all he had ever learnt about physical geography and start all over again in Southern Colorado.

At first I was puzzled in the extreme to see how the mountains rose suddenly out of the great plains, without 
any warning almost, and without the customary foothills and valleys that one would expect to see clustering around a mountain range of several thousands of feet in height. Afterwards I became accustomed to this unusual formation, when I found that mountains always grow that way in the Far West, and particularly farther on in New Mexico and Arizona. All their ranges seemed like elongated "Wrekins" set in a plain of gigantic dimensions.

At Aguilar, half-way on the road to Trinidad, I met the first really Mexican town. It will be remembered that all the south-western States once belonged to Mexico and one by one they have been ceded or bought or otherwise appropriated until Mexico now is only a shadow of its former self. Nevertheless a large proportion of the population is still Mexican, in spite of the continued influx of American settlers, and consequently Mexican is spoken almost universally in addition to English as the national tongue.

Trinidad styles itself "The industrial and commercial centre of S.E. Colorado." With a population of something in the region of 14,000 , it stands at the base of Fisher's Peak (10,000 feet), and it is an admirable example of the inextricable mixtures of Old Mexico and New America in the cities of the West. I took its picture and left its shining well-paved streets to track down my old friend, the Santa Fé Trail.

I got one mile away from the town and then struck. The trail climbed rapidly, skirting the Peak all the time in preparation for the Raton Pass soon to follow, which cuts right over the Rocky Mountains into New Mexico. That in itself was nothing. I am always game for a good hill-climb. But I had thought better of the Santa 
Fé Trail. After climbing 1,000 feet in just over a mile, it changed into the most absurd hotch-potch of ruts and mud-heaps that ever eye witnessed, and this for as far as one could see. The condition of the road strained my credulity to breaking point. Getting through the far-off mud-hole at Hume in Indiana was a child's tea-party compared with this. In half an hour I did just 100 yards and then, after resolutely determining to return to Trinidad and take the train, I found that to go back was as much out of the question as to go forward. It simply couldn't be done single-handed. To turn Lizzie round would require nothing less than a sky-hook and pulley-blocks.

I left her standing in a huge rut in the middle of the road and reconnoitred to see how far this appalling state of affairs continued.

Fortunately a Flivver appeared round a bend in the road ahead, coming in the opposite direction. It heaved and swayed and bumped and side-slipped and hiccoughed its way along. I watched it until it finally reached the spot where Lizzie blocked the way. Then something had to be done. The car had two occupants, both hefty-looking men, whom I enlisted to my aid. Together we lifted and pulled and heaved and pushed until the worst was past, and then I struggled on alone.

Farther into the mountains we travelled; higher and higher we climbed. In places the trail was hewn out of the rugged mountain sides, and except in a few places there was hardly room for more than one vehicle to pass. Occasionally a "washout" would be encountered where a mountain stream had encroached on the road and washed it away altogether. Then would come a short 
detour over a gap in the bank, with the grassy slope strewn with branches and small tree-trunks to prevent the unfortunate vehicle sinking in and thus permanently blocking all progress that way.

The ascent of the Raton Mountains by the Raton Pass is made amongst some of the most beautiful scenery imaginable. The trail is only visible a few yards ahead and is lost in sudden twists and turns as gradually the mountain slopes are devoured. On the right, almost behind, are still to be seen the famous Spanish Peaks towering like twins in solitude above the rest of the Sangre de Cristo range, some forty miles away. Soon we shall be leaving Colorado State behind us-Colorado the Glorious, the Beautiful, the Great.

It is said that "amongst all the mountain kingdoms, Colorado seems to stand easily first in physical adornment: not even Switzerland and her Alps offering more than a fair comparison." Mont Blanc, the highest peak in the Alps, is 15,784 feet high, while Colorado has many peaks lacking little of this height. The lowest depths of some of Colorado's famous parks are higher than the average height of the Alpine Chain.

Upward we climb, amid thickly-wooded mountain tops, round thrilling bends and tortuous precipices and over the rockiest of roads. The end is in sight. A depression in the sky-line ahead shows where the Raton Pass (7,620 feet to be exact) reaches its highest point and gazes forwards into the heart of New Mexico and behind into the vastnesses of Colorado.

A gradual bend, a sudden swerve, and then-the summit is reached. Colorado is passed. Before us lies a great and thickly-wooded valley, broad and deep and beautiful. Beyond lie the great plains of New Mexico, 
plains so vast that in their utter defiance of limit and dimension they beggar description. The eye could not follow the great expanse. So immense were the distances that the earth merged indefinitely into the sky at the horizon. Dotted and strewn here and there were hills and mountain ranges that seemed to have sprung up so suddenly out of the plateau to have really no connection with them.

Here I stood at the gate of another world. Before me lay a land of mystery and romance, a land of health for body and soul; a land of desert and sage-bush, of cactus and strange vegetation; a land of antiquity unparalleled by any other in the world. Here at my feet lay New Mexico and beyond, Arizona, the two States that at the same time are the oldest and the youngest in America. Although only admitted to the Union in 1912, their history dates from remote ages when they were peopled by a race unknown to-day but nevertheless well advanced on the road to civilization, a race that built cities while Babylon was as yet unknown, and laid down irrigation systems that puzzle the engineers of the present day.

Arizona and New Mexico, you are the pearls of great price that no human being has ever yet valued at your true worth. When the day shall come that man can say of you, "I have seen you in all your moods and have discovered all your secrets," then this old earth will be a lifeless, soulless, aimless globe, its purpose fulfilled, its course completed.

A five mile descent through the scented pinetrees brought me to Raton, another half-Mexican, half-American town, small but modern and well-arranged. "No more 'rooming-houses' for me," I resolved and turned my 
gaze to the far-distant plains where the darkness was slowly gathering.

Even in New Mexico, one need never go without a meal. The way to an Englishman's heart is through his stomach (this applies also to Americans and most human beings in general !). My heart was greatly touched by Raton in this manner, and shortly before dusk I was speeding on my way southwards towards Santa Fé.

Ten miles out the trail crossed a river. It must have been the Canadian River, a tributary of the Arkansas, which it joins several hundred miles to the east. The surrounding country was desolation and solitude itself. Half prairie, half waste, almost desert, it was a country of new sensations. Just to the west, from horizon to horizon, stretched the gaunt and rugged Sangre de Cristo range, dark and threatening always in their aspect. Not a living thing was in sight, not even a suggestion of life. I ran Lizzie off the road to the brink of the river and laid down my bed in the silver rays of the rising moon.

At 6.30 in the morning the sky was ruddy and the air pure with the fresh breezes of the dawn. From minute to minute the myriad colours of the mountains changed their tints as the sun rose higher in the Mexican sky. I continued on my way.

The road was broad and good, but a surprise was in store. After a few miles there appeared a dilapidated signpost where a bedraggled pathway joined the broad highway through a gap in the fence which now ran alongside. It bore the legend "To Santa Fé" and pointed through the fence to the left. My first impression was that some small boy had been playing pranks. It was inconceivable that these two ruts but a few inches 
wide in the coarse green grass should lead to Santa Fé while there, straight on, was a good broad highroad that led nowhere. It ran clear ahead and was lost over the brow of a hill. I never found where that road went. I have never seen it on any map and have made many inquiries since. Some travellers, like myself, had seen that road and wavered, but not one had gone that way and could enlighten me.

New Mexico is not a nice country in which to lose oneself. Towns are very few, and often one can go a hundred miles without seeing a village or meeting a soul. So in spite of the temptation I swerved to the left and entered the field that was without corn or pasture, following those two ruts that cut deep into the prairie soil and were not visible more than 50 or 100 yards ahead at the most. In places the two ruts had become too deep for further use and another pair had been started at the side, running parallel with the original ones. When these had worn too far another pair had sprung up, and in many places I counted eight distinct pairs of ruts running side by side across the prairie, each representing a distinct phase in the evolution of the Santa Fé Trail. At any point, if one looks far and long enough, one can find the original tracks that centuries ago were formed by the old prairie-schooners as they journeyed westward across the plains to Santa Fé.

The next town lay far across the plains beyond the horizon. I should have to hurry if I were to get any breakfast, but the riding was rough. Tufts of coarse grass and sharp stones covered the prairie and held back the speed; here and there were the holes of prairiedogs, who respect no one in their choice of a site. If it pleases them to build their front-door entrance where 
your favourite inter-rut strip happens to be, well, they build it there. Their holes are generally about six inches in diameter, the mouth being funnel-shaped. Passing vehicles smash them in until the opening is sometimes two or three feet across. Our friend the prairie-dog doesn't mind in the least. He continues to live there in spite of the traffic and never a curse escapes his lips. $\mathrm{He}$ is a dear little animal. One cannot help loving him. In stature these animals have the characteristic of both a squirrel and a rabbit, and are about a foot in length. They sit on their fat little haunches like a squirrel, but have only a little bobbed tail like a rabbit. I believe they are the most friendly rodents in existence, and have the reputation of dwelling in friendship even with rattlesnakes, who never harm them! If you surprise one when he is away from home, he watches you, motionless, to see if he has been seen, if only a few feet from the intruder. And when he sees that you have seen, away he runs with his head well down and his little tail well up until he reaches his burrow in the flat prairie. This done, he considers himself safe, turns round, sits on his haunches and stares inquiringly at you. But if you dare come too close he disappears in a second and is seen no more.

One cannot help laughing at the antics of these amusing little animals as they scamper off like month-old puppy dogs. Ofttimes I have chased one to his hole in the road and watched the anxious look on his face as for a brief moment he turns his head before flashing into the ground below your front wheel. No true traveller could harm one of these innocent little beasts ; they are often his only companions for hundreds of miles.

Ten, twenty, thirty miles I travelled over the almost 
trackless prairie. Occasional mud-pools barred the way, but when the trail was unfenced, these were easily avoided. Later on fences appeared, limiting the road from some neighbouring ranch. I judged I was getting near to Springer.

An old shack of a two-seater car hove in sight, coming in the opposite direction; I had an opportunity of studying it in detail as it came close up. Naturally we both stopped. All travellers are friends in the Far West, where distances are great and people are few.

"Guess you'd better follow us if you want to get to Springer this week," essayed the driver.

"Why, is there any mud about?"

"Mud? There's a hole down there outside the town that we've been trying to get either in or out of these two-and-a-half hours. Had to get some hosses to pull us backwards out of it in the end. Gosh, I've never seen a mud-hole like it in all my days. We kin get around another way though, I'm told. Where you headin' for, stranger?"

"Santa Fé."

" Oh, we was expectin' to get to Santa Fé this mornin'. We're bound for El Paso, and must get there by tomorrow."

I reflected that El Paso was in Texas on the Mexican border, some 500 miles to the south! "Well, if you don't mind, I'll come along to Santa Fé with you, so then we can each help dig each other out of any holes that happen along."

"Righto, glad to have your company, but we're not speed merchants like I guess you are with that 'oss there."

"Don't make any mistake, brother. I passed the 
speed craze a thousand miles back. It doesn't pay."

So we retraced our tracks, the car leading. It was shorn entirely of mudwings and footboards to save the wheels becoming clogged or the running boards fouling the road. On the back was strapped a large trunk. This I found is the usual way of travel by "auto" in the West. Seldom does one see wings on a car that is driven for any distance from home. Running boards, if present, are generally of an improvised variety made by planks suspended and fastened in place by ropes around the body work. Thus the road clearance is increased and the necessity for constant cleaning removed. By far the most popular "machine" is the Ford. You can buy one cheap and sell it as scrap when the journey, if a long one, is finished. Owners of large expensive touring cars very often have a Ford as well for emergencies and for long distance travelling. In New Mexico and Arizona I have seen scores of huge touring cars stuck helplessly in the road and often abandoned altogether until the seasons permit of their removal.

I followed my friends from Texas along little pathways and rough tracks strewn with boulders, through gaps in fences, across fields and back gardens, all, to my mind, at an alarming pace. It was only with difficulty that I kept up with them at all, owing to the many ruts and rocks and other obstructions that are far more hindering to two wheels than four.

Arrived eventually in Springer, I resolved to postpone the promised meal until later in the day.

We passed many ranches and crossed many mud-holes, some of alarming width across. In most I managed to fall off at least once and wallowed in the mud. Some- 
times the car got so far ahead as to be lost altogether, but after each encounter with a mud-lake I managed to make up the lost time.

Thus passed nearly thirty miles in which I realized the utter absurdity of two wheels compared with four. At one place I lost so much time that I began to give up as hopeless the attempt to keep up with the car ahead. After all, what was the use? Once out of the mire, however, the trail became better and turned into loose sand for many miles.

Over this sand I made good progress. It was now nearly midday, and I had visions of a meal in Wagonmound, a small village some twenty miles away. The appetite was there all right, and as I trimmed off mile after mile at good speed I forgot all about mudholes and the like.

All at once the engine burst into a wild roar and Lizzie began to slow down. What new trouble was this? A broken chain, or something worse? I stopped as quickly as I could and proceeded to an examination of the transmission. The chain was all right, but the engine sprocket had almost come right off the driving shaft. The key and nut, where were they ?

For an hour I searched up and down in the sand and in the grass at the roadside for the missing parts, but without success. The sun was almost vertically above and its rays poured down unmercifully from a cloudless sky. There was not a sign of water or of any living thing in any direction.

I returned to another examination to discover whether I could remove a nut from any other part of the machine to replace the defaulter. Not a nut was there anywhere that at all approached either the size or the thread re- 
quired. I searched once more, wondering in how many days' time another vehicle would pass that way, and half resolved to walk the next twenty miles.

What! Leave Lizzie and walk! Never!

Another hour elapsed. I had explored all the ruts and searched every inch of the road for half a mile back. I stopped, and wondered where I could find water to drink. Water would be even more acceptable than the nut and key now. I scanned the sun-baked prairie in all directions. From horizon to horizon there was nothing but the solitary distant mountains, and here and there a lonely parched-up hill. Truly a nice outlook! Henceforth I would carry a water-bag with me.

I decided to return to Lizzie, push her off the road and try walking. But just to think of coming 3,000 miles in her constant company, and then having to forsake her ! "Poor old Lizzie, she's a dear old crock," I murmured to myself.

What was that? I stooped down to see, and there hidden in a crack in the hard mud was the missing key. That put a different aspect on matters altogether. The nut would in all probability not be far away. I set out to explore every stone and every rut and every crack. Sure enough I found it not very far away.

In a few minutes the midsummer air was whistling past my ears once again.

In ten minutes $I$ found myself surveying the biggest thing in mud-lakes that it has ever been my misfortune to negotiate. The road was fenced in, naturally. There was a ranch on either side of it. The lake of mud extended sideways to the very borders of the road, ninety feet wide. The distance across was about fifty yards. I estimated that the mud and water were waist-deep in 
the middle. Ridges and furrows of harder mud, where passing cars had churned it up, in a desperate attempt to get through, led into the sickly mass and then were lost.

"This requires a scientist, not a motor-cyclist, to cross," I averred, and, propping Lizzie upon her stand, went to reconnoitre.

I then created a precedent in the art of crossing mudholes by which I benefited on all future occasions. I was wearing water-tight field boots which came up to my knees. The modus operandi was this: I would select a likely-looking rut and walk along it as far as I could without the water coming over the top of my boots. If it came over I went back and tried another one. This process was repeated until I had a good idea how the land lay. If I could possibly get through without the mud reaching my knees, I knew I could get Lizzie through all right. This manner of prospecting in advance I found indispensable and at the same time perfectly suocessful.

I got through somehow, but prayed that I should never meet another like THAT.

I rolled into Wagonmound about three in the afternoon a very weary and mud-stained traveller. When I got there, it started to rain; it naturally would.

There is but one restaurant in Wagonmound, which enjoys a population of 200 or so Mexican-Americans. Here I learnt that there had been a "cloud-burst" near Santa Fé but a few days back; also that the oldest inhabitants of New Mexico had never known so much rain to fall as this summer; also that the roads ahead were almost impassable; also that at one place on the other side of Santa Fé and at a distance of fifty miles between two towns there were one hundred cars stranded 
in the mud and abandoned! I was proof against it all, however. I considered that by now I could get through anywhere. I was not to be daunted by fancy yarns and sceptical reports. Time was when I cursed the Americans for being optimistic about their roads. That stage had long since been passed. Now I was proof against even their pessimisms and discouragements.

The rain stopped and I proceeded once more, determined to make a big effort to reach Santa Fé that night, though still ninety miles away.

At Wagonmound there was a station of the Santa Fé Railway, which for a good distance ran close to the trail. I inquired at the "Depot" what were the chances of travelling on the track. I did not want to try conclusions with any trans-continental trains if avoidable.

"What! Ride in the track!" ejaculated the linemaster. "You can't do that!"

"Oh, I guess I can if I'm careful," was my response.

"Waal, I jest guess you can't, my friend," was his rejoinder. "I'll have you arrested if you try to work that stunt."

Argument was useless. "D'ye think I want to damage your bloomin' old track?" I asked him heatedly after much discussion. We settled the matter finally by my tendering the information that $I$ would ride up and down his track all day long if I wanted to (not much fear of such a desire developing!) and if he liked he could "write to John Bull about it"!

The humour of the situation was lost upon him. "You'll get shot," was his reply, whereat we parted. 


\section{CHAPTER XIV}

\section{NEW MEXICO}

I set out from Wagonmound with a light heart and a heavy stomach.

The road ran parallel with the rail for a mile, then crossed over by a level crossing and continued parallel on the other side. I did not get far. No doubt there had been unusual rain; great fields were now lakes with the grass bottom not always visible; little streams, normally no more than the size of a small spring, were now swollen rivers. These crossed the road in places. The road was fenced in. And thereby hangs a tale.

After precisely half an hour I found myself just three miles advanced, and in the midst of a hopeless chaos of sun-dried emaciated mud. I had "explored every avenue" of the road, but found none possible of negotiation. Bit by bit I dragged Lizzie back and returned to the level-crossing. Come what may I would try the track. Even if the sleepers shook my very bones to powder it would be better than eternally forging through the mud of New Mexico.

On each side of the road where it crossed the rails the track was guarded by a satanic device in the form of spikes and knife-edges skilfully arranged and extending to a distance of several yards. The function of these was evidently to prevent cattle and other animals straying on the line. Traversing these was no easy task. If 
one did not ride on top of the spikes, one's tyres wedged in between the knives. Once past, the rest seemed easy. But things are not what they seem, especially on railroad tracks. The sleepers were not ballasted and were anything but level. There was no room outside the track, for it was steeply banked, and the sleepers projected beyond the rails into space. At every few hundred yards the track ran over a brick bridge spanning a bog or a stream. The bridge was just the width of the rails apart. But when it came to riding-ugh! As every sleeper was passed, the wheels fell momentarily into the intervening space between it and the next, and a series of sudden, sharp shocks was hammered through Lizzie's poor frame as each sleeper in turn was struck by the front wheel. The faster I went the quicker and smaller were the shocks, and above a certain speed it was quite tolerable running.

I was just getting up a comfortable speed when I imagined $I$ heard the whistle of a locomotive behind. This was discouraging and certainly unexpected. I stopped quickly and looked back. Sure enough there was a train coming, but it was easily half a mile away. To go forward in the hope of out-pacing it would be useless. There was not even room to get off the track, for once I got down the steep bank, I knew it would be next to impossible to get back again, or to get anywhere, for that matter.

Neither was there room to turn round and go back. More than ever before did it appear to me that discretion was better than valour.

So I commenced to push Lizzie backwards to the level crossing, prepared to roll sideways over the bank if I found the train got there first. 


\section{ACROSS AMERICA BY MOTOR-CYCLE}

I was just beginning to feel sure about winning the race, and judged that $I$ should get there with a good hundred yards to spare. I reached the crossing, but as naturally as one would expect, the back wheel wedged tight between the knives of the cow-guard.

\section{Would she budge? No.}

As I struggled and heaved (I could not look on and see Lizzie go west in such an absurd fashion), the "California Limited" bore down upon me. Fortunately American trains do not always go so fast as they might; at any rate, not so fast as one thinks they should when one is travelling in them.

With a final desperate lunge, Lizzie yielded to my efforts and came unstuck. No time was lost in getting out of the way. Fifteen seconds afterwards the train rolled by at a modest thirty. She had evidently not got properly under way since her stop at Wagonmound.

I returned to the mud-hole like a smacked puppy with its tail between its legs, and reflected on what might have been.

But it was no use. I stuck again.

This time I was well armed with refreshments. I had bought six bottles of a ginger-pop concoction from the last village. I carried one in each pocket and the other two as reserves, only to be used in case of great emergency, enveloped in the blanket strapped on the carrier.

I drank one bottle at the close of every engagement with the road. But after an hour I was still no farther ahead. I reclined on the bank and waited for something to turn up.

Fact revealed itself stranger than fiction once more. Something turned up very speedily. It came in the 
form of a "Marmon" touring car, bearing a Californian number-plate. I had taken the precaution, of course, to leave Lizzie in the right spot, so that no disinclined passer-by could get through if he wanted to. After all, one musn't RELY on everyone playing the Good Samaritan.

The two occupants of the car were courtesy itself. They not only assisted me in lifting Lizzie over the pièce de résistance, but also showed considerable interest in me. Out here, where friendship between motorists is much more marked (almost as a matter of necessity), there is seldom any need for anxiety, and it is remarkable how potent a thing is this roadside courtesy. Practically every town I stopped at afterwards had heard of the strange traveller who was coming along on a 10 h.p. motor-cycle, and awaited my arrival with interest.

"Had a fella in here on his way to California told us about you," said one garage hand, in the heart of Arizona. "Said you'd be here sooner or later."

"Oh yes? And how long ago was that?" I queried.

"Um-guess well over a couple of weeks ago." (The word "fortnight" is unknown in America.)

Such little incidents happened many times, and these, coupled with the amazing reports that had been circulated by the Western Press about me since that inflammatory article on "Roads," etc., in the Kansas City Star, had generally managed to achieve for me quite a notorious reputation in most towns long before I ever rattled into their midst.

It was now nearly fifty miles to the next town. I pushed ahead as fast as I could to reach it before dark. Progress, however, was slow. In places where the road 
was not fenced, I rode upon the rocky prairie. It was, for the most part, a considerable improvement, and one could ride around the bogs and mud-holes instead of crossing them.

Never had I been in such wild and barren country. It was quite beyond hope of cultivation in most places, being strewn with rough stones, rocks, and boulders, and only sparsely covered with meagre-looking grass which, in its efforts to keep alive at all, had to arrange itself in small tufts dotted here and there in order to derive the maximum nutriment from the scanty, unfruitful soil. The country itself changed from flat to hilly as the Sangre de Cristo range once more drew nearer, When it became hilly, great rocks projected through the surface of the trail, which seldom or never swerved to avoid them.

The trail itself resolved itself later on into no more than a mere medley of ruts and grass-bare strips of all widths, running and crossing each other at all angles and in all directions. There was no time to look around and enjoy the wild scenery or study the ever-changing sky-line; it was " eyes on the road" all the time. It was quite impossible to dodge more than a fraction of the rocks and boulders, and one was always abruptly brought back to stern reality, if for an instant one's thoughts diverged to other things, by a sudden shock from one's front wheel, or a sickening crash on the bottom or side of the crank-case.

It was a slow job, and travelling was more in the line of a mountain goat than a motor-cycle. I was ultimately satisfied if I could average eight or ten miles an hour.

After thirty miles of this, I was surprised to discern ahead something which looked like a caravan. There 
were two vehicles, apparently joined together, but with no visible means of locomotion. Nevertheless they moved slowly. I judged that some enthusiast of the "See America first" order had converted a Ford into a travelling home, or maybe a wandering tribe of gipsies had become sufficiently modernized to appreciate the benefits of auto $v$. horse transport.

I caught them up and stopped to have a chat. Both sides seemed curious at the other's means of locomotion, and wanted to know the why and the wherefore.

The team, I found, consisted as I had surmised of a Ford chassis, on which had been skilfully built a caravan body. Behind was a trailer, on two wheels, and of construction similar to, but smaller than, the other. Evidently one was the parlour, kitchen, and store-room, and the other the bedroom.

The driver stopped his engine and jumped down.

"Good day, sir; how do ?" I inquired.

"Very fit, thanks; you the same? How in Heavens'n earth d'you manage to get along on THAT?":

"Mostly by plenty of bad language and good driving," I returned. "And what in the world arc you doing in this benighted place with THAT?"

"Oh, I'm goin' west. . . . "

"Shouldn't be at all surprised at that!"

"I'm bound for somewhere in Arizona. Come from Chicago. Fed up with the life there, so I'm out for a change. Looking for a likely spot to settle down where there's plenty of fresh air."

"What! You've come all the way from Chicago on тHAт?". I inquired incredulously.

"Sure enough.".

"How long has it taken you?" (I was already 
becoming sufficiently Americanized, the reader will observe.)

"Best part of three months."

"How many with you?

"Wife and two children. Here they are."

"Well, I wish you luck, brother; but it doesn't strike me that the roads are ideal from a furnitureremoving point of view, so to speak."

"Roads ?" (Here he waxed furious: I had touched a sore spot.) "Don't talk to me about roads. The gor-dem Government oughta a' bin shot that provided roads like this. Just think that across a civilized country like America there isn't a dem road fit to drive a cow on to !"

"Ah, I've thought that way myself; but there's a fallacy in the observation, old man."

"What d'ya mean ?"

" Just this-who told you America was a civilized country ?"

Long pause.

"Aye, you've said it," and he relapsed into a stony silence.

I bade him farewell, and left him scrambling slowly over the rocks and mounds, while the caravan rocked from side to side and jerked its weary way along. I reflected also that, after all, THAT was the way to see the country.

At dark I was but a few miles from Las Vegas. Once. again heavy clouds rolled over the sky. Rain began to fall. My spirits did likewise. I wondered whether it was a habit. But what cared I for rain or mud ? By now surely I was proof against them. I struggled on. And ultimately I got there. 
Las Vegas is a fair-sized town. In order of merit it is the second largest in New Mexico. The first is Albuquerque and the third is the capital, Santa Fé. There are no more towns of any size in New Mexico. Including native Indian villages there are, in addition, in the whole of New Mexico, some seventy or eighty small towns and very small villages, making the total population of the whole State about 50,000. When it is understood that New Mexico is about four times the area of England, the reader will be able to form an idea of the sparsity of its people.

Now most people would have predicted that immediately on my arrival in Las Vegas I would have sought out the best hotel and consumed a big square meal. I did no such thing. I went to the movies instead.

Then I returned and went to bed, half wondering whether to standardize the one-meal-per-day experiment for future requirements.

In the morning it was not raining, but all the time until midday it showed signs of just commencing.

At midday I became impatient and started out for Santa Fé. I had just left the outskirts of the town when it did finally and irrevocably decide to rain after all. I continued for five miles, when a Ford car hove in sight. "Here goes for a chat and some straight dope on the subject of roads to come," said I to myself and stopped. The Ford stopped also. It had two occupants, a man and his wife. They both looked bored, so we made a merry party.

"What's the road like back there?" I inquired.

"Mighty rough-mighty rough. They get better the further east we come." 
"Do you think I shall be able to get through to the coast ?"

"Well, it's mighty hard riding, but I guess you ought to be able to get through. Oh, but stay a minute, there's a big wash-out before you get to Santa Fé-big stone bridge washed clean away with the floods, not a trace of it left. I don't know much about motor-cycles, but I guess you could get across the river all right. You'll want to be careful though. There was a whole cartload of people washed down the river last week, so they say; all of 'em went west, horse and cart and all!"

"Ah well, that'll add a bit of excitement to the trip. I'm good at crossing rivers."

" Ugh! Guess you'll not be looking out for any excitement time you've gotten to Santa Fé!"

I was particularly interested in these people's domestic arrangements. Without a doubt $I$ have never seen an ordinary touring car, much less a Ford, equipped and arranged in such excellent style. They carried with them a portable stove on which could be cooked any dish they required. They carried ample supplies of vegetables, fruits, eggs, butter, bacon, bread and tinned goods, and even tanks of fresh water for culinary and drinking purposes. This is certainly a wise precaution, because it is never safe to drink water from even the most tempting of rivers in the West. Furthermore, they had two collapsible beds, which could be laid upon the top of the seats from back to front, and which were fully equipped with feather mattresses and blankets! One would think that all this paraphernalia would have taken up an enormous amount of room. Not so. Apart from the fact that the back part of the car was neatly covered in, there was not the slightest sign that the car was anything 
but an ordinary Ford with a lot of luggage in the back.

I bade them farewell only on the strict condition that if the rain continued $I$ should return and share their supper. They would not be far away, they told me. The plat $d u$ jour was salmon and Mayonnaise sauce, above all things!

Still, it is a habit of mine never to go back, however tempting the circumstances. At intervals $I$ passed a few Mexicans driving teams of horses, and once more I was alone with Lizzie. As a compensation for the drizzling rain, the scenery was perfect. The trail had now swerved into rugged, mountainous scenery, thickly wooded, wild and picturesque in the extreme. It was almost ridiculous to watch how the narrow trail dodged in and out of the trees, cutting across small forests of cedar, aspen, and pine, curving to right and left round some awkward prominence, now dipping down suddenly into a little valley, and then darting up over hilly slopes all strewn with loose rocks and broken with jutting crags.

We were approaching the Pecos, the haunts of the bear and mountain-lion, and the headquarters of numerous tourists and campers attracted thither by the fine fishing, shooting, riding, and mountain-climbing.

Occasionally, as one took a sudden swerve around the face of a projecting hill, one would see, away there in the valley beyond, a Mexican village set back from the road, and would marvel at the strange sight of the square mud buildings, congregated together in such unique and regular formation. The brick-red hue of the houses was so near to that of the surrounding country as almost to hide the village altogether from view, even though it was right " under one's nose." 
My first impression of a Mexican village was one of amazement. To think that several hundred people can live together in those single-storied mud huts in peace and comfort, with ne'er a sheet of glass in the windows and seldom a door within the door-postswell, it was absurd! But my second impression absorbed the first entirely, and was one of appreciation for the primitive beauty of these native dwellings. It is a beauty that lingers in one's memory, a beauty that lies in natural flowing forms, defying the unrelenting sharp corners of modern architecture. And I have seen many "adobe" houses in New Mexico that would be far more comfortable to live in than many that have sheltered my bones in Europe!

I was meditating thus when the sound of rushing waters reached my ears. Sure enough, the road ended abruptly, like a cliff, and continued in like fashion on the opposite side. Between, and several feet below, swirled the River Pecos. It was still swollen with rain from the mountains, although it had evidently been much higher recently.

Not a soul was about. There was a solitary Mexican house on a hill to one side. I contemplated the river in silence, save for the sound of its waters as they swirled over the rocky bed and now and then dislodged a weighty boulder.

To the right two rickety planks had been erected, supported partly by ropes and partly by vertical props from rocks in the river, for pedestrians to cross. I wondered what pedestrian would find himself in these parts!

To the left, a detour had somehow been dug at an angle of about 20 degrees to the water's edge. In the opposite bank a similar detour had been dug, but at an angle of 
about 30 degrees. Evidently several cars had already passed through the river that way. But a car is not a motor-cycle. I meditated. A car on four wheels could not only hold its own better in the middle of the torrent, but could also get up the opposite bank easier. One thing was quite certain-even if I got through the river all right, it would require a superhuman effort to push the machine up the steep, greasy incline on the opposite side.

I reconnoitred up and down the river bank in the hope of finding a better place to cross, but the quest was in vain. The banks grew steeper and higher and the riverbed wider and rougher than ever. I returned to Lizzie and said a prayer for her. Then I took off my tunic and removed the bag and blanket from the carrier.

I judged that it would be expedient to rely upon momentum as far as possible, as the engine would certainly not run for long under water, so, starting the engine once more, I put in the bottom gear and charged down the greasy slope into the river.

There was a tremendous hiss, and a cloud of steam went heavenwards. The engine stopped long before I reached the middle, and the smooth nature of the loose rocks that formed the river-bed was treacherous for two wheels. There was nothing for it when the engine stopped but to dismount quickly and push. When I reached the middle, the water was up to my waist, and it took most of my strength to keep the machine upright and hold it against the force of the river, which swirled around the cylinders and washed up against the tank. I managed to avoid being washed away, however, thanks to the great weight of the machine, and got her to the opposite bank. 


\section{ACROSS AMERICA BY MOTOR-CYCLE}

It was a relief to be out of the water, but the task still remained of climbing up the bank. I exerted all my strength, but the slope was so greasy that neither my feet nor the wheels would grip on anything. Twice or thrice I got it half-way up, only to slither down to the river again tout ensemble. Then I tried the expedient of wedging a huge stone under the back wheel and pushing an inch or two at a time. But it was no use. The grease was impossible. I laboured with it for a quarter of an hour.

I was just on the point of giving it up after we had all slid down to the bottom once again, when a huge Mexican appeared on the scene. He was evidently the owner of the house on the opposite bank, and looked hefty enough to lift a tram.

We pushed with our united effort. We slipped and slithered and wallowed about, but we got to the top. I breathed a sigh of relief, rewarded the Mexican liberally, and walked across the plank to bring my tunic and luggage.

Lizzie had never been so clean since the day she came out of the crate. Every speck of mud and dirt had been washed clean away. and her pristine beauty was revealed once again. It was an hour's task to dry the carburettor and the magneto and get the engine running. It was getting dark when $I$ got going again. The rain had stopped, but the mud was terrible. Every half-mile I had to stop and poke it out of the mud-guards with a screwdriver.

Eventually, just before dark, I reached the tiny Mexican village of Pecos, called after the river in the locality. It consisted mainly of a general store and "rooming-house" for the benefit of stranded travellers. 
A rooming-house, by the way, is a kind of boarding-house but with no accommodation for meals.

At Pecos I was surprised to see an Indian motor-cycle and side-car "parked" on a strip of green, which in generations to come would be the plaza or square. Examination revealed it to be a most remarkable machine. It was equipped with tool-boxes galore at every available place and, strange to remark, there was a small emery wheel mounted skilfully on the top tube and driven by a round belt from a pulley on the engine shaft. There was also a small hand-vice clipped to the frame, and numerous other small tools and fitments, which, to say the least, were not usually found in the equipment of a motor-cycle.

"Well," I said to myself, "if all this paraphernalia is required to get a motor-cycle across to the coast, I'm in for a rough time."

But I was relieved to find that it was the property of a tinsmith who, out for a holiday, combined business with pleasure, and repaircd people's tanks and pots and pans wherever he went! In this way he not only defrayed his travelling expenses, but made a far better income than he used to get in his home-town in Ohio.

He was a tall, burly-looking chap, and greeted me with effusion. In like manner did I welcome him. The sight of another motor-cyclist removed my worst apprehensions.

"Strike me pink!" quoth I, "I thought I was the only madman in this part of the world!"

He glanced at my number-plate.

"Gee, brother, put it right there. I wuz beginnin' to think I'd never see another motorsickle agin; you goin' to the coast?"' 
“"That's where I'm heading for, but of late I'm not so sure about getting there as I was when I left New York."

"Oh, boy, yew'll git there all right if yew've come this far-I said it; but say, there's some smart bits o' travellin' to do ahead on yer!"

"What? Is it worse than what I've passed?"

"Waal, I've bin there an' got back-travellin' with the missus here-an' I tell you, the road gets better the further east I come. And what's more'n that, brother, yew've got some mighty warm times ahead before you see California-like goin' through Hell, it is. Wait till you find yourself in the middle o' the Mohave Desert with the sun beatin' down at 130 in the shade, and no shade-no nothin' except prickly pears and funnylookin' cactuses and a bit of sage-bush here and there. Say, boy, wait till you see piles o' bones and carcasses by the score lyin' at the side o' the road, an' yew'll begin to think it's warm, all right. Whatever you do, boy, take water with yer. Yew'll drink GALLoNs of it!"

"How long have you been here, then ?" I asked.

" Nigh on a couple o' weeks, brother. We've bin waitin' fer the rain to clear off."

Truly a bright prospect.

I slept well that night, in spite of the fact that my day's mileage was only thirty, and awoke to find the sky clear and promising.

I spent the morning in tuning Lizzie and making minor adjustments and preparation. I commissioned my tinsmith friend to make me a new accumulator box, my own having become entirely disintegrated with the vibration. For 1,000 miles it had been held together with straps fastened tightly round it to the frame. 
The distance to Santa Fé was only twenty-five miles, so I judged I should be able to reach it that day.

Those twenty-five miles took four hours. I will not attempt to describe those four hours. They were filled to the brim with mud, rain, wash-outs, and bridgeless rivers. In many places there were great "washes" of sand brought down from the hillsides that nearly completely obliterated the trail as it struggled across the mountains.

It was a very weary motor-cyclist indeed who rattled into Santa Fé at 5.30 that afternoon. And that motorcyclist had quite made up his mind to have a few days' rest before anything else happened his way.

With a deep sigh of relief I leant Lizzie up against the pavement opposite the "Montezuma Hotel." With heavy, aching limbs and sodden, mud-stained clothes, I walked towards the door.

It opened ahead of me.

"Ah! how do you do, Captain Shepherd? We've been expecting you for over a week. Come right in. We know all about you. Here, James, take Captain Shepherd up to his room at once. No, don't bother to say anything. Just go and have a good hot bath."

It was the voice of an angel that spokel 


\section{CHAPTER XV}

\section{SANTA FE}

Santa Fé is the most delightful of places. It has a charm all its own. It is small, quaint, and intensely old. It is far removed from other American townsjust as far as west is from east. It represents thc quintessence of New Mexico, and at the same timeso it is alleged-sets the standard of art in America.]

The first words of a mediocre Easterner when he enters the plaza of Santa Fé are "Heavens'n earth! what kind of a hole have I struck now ?" But if he has a soul underlying that eastern veneer of his, if he has an appreciation for art and beauty in architecture unimpaired by familiarity with gigantic skyscrapers, he will repent those words. His disdainful grin as he first catches sight of the Art Museum and sees an edifice of mud with ne'er a corner that could be called sharp, will fade slowly from his face, and once he has recovered from the shock of the "sudden uniqueness" of everything, his look will turn to one of wonder and admiration.

Santa Fé is small. It contains no more than 6,000 inhabitants-a curious mixture of Mexicans, Indians, and Americans. Its population, moreover, is at a standstill. As the capital of a State of 160,000 square miles, it seems ludicrous, until one reflects that there are but 50,000 people in the whole country. Of Spanish origin, it is laid out in Spanish style, with the plaza 
or public square in the centre. Around the plaza are arranged most of the more important buildings. These, with few exceptions, follow closely the "adobe" architecture of the "Pueblo" Indians, combined with the architecture of the later "Franciscan" Missions that were instituted by the Spanish Friars, who in the early days of colonization penetrated far into the continent.

In the forefront of every march and every exploration there was always the brown-robed Franciscan, bearing along with his crucifix the trowel and the book. To convert, to build, and to teach-these were the selfimposed tasks to which he consecrated his life. Especially do we honour him as a builder. Living among a passionate people, who resented the intrusion of strange gods among their own, often surrounded by cruel and relentless foes, the type of his structures was determined by the conditions of his existence. There must be a church in which to preach the new religion, a convent in which to live, and along with these, a school in which he might give instruction. These must be connected and compactly placed to serve as a fortress against present enemies; and they must be massive, to withstand the ravages of time. There were eleven such churches in New Mexico alone prior to the landing of the Mayflower-and more than fifty others were established during the century which followed.

This is the only type of architecture that can be referred to as truly "American," saving perhaps the unenvied skyscraper of the East. This latter, however, belongs to no school and knows no creed; it is not indigenous to the soil or produced by environment, native material, or climate. Instead, it defiles the heavens and cuts 
the landscape into futuristic nightmares of edge and angle.

By far the choicest flower of this renaissance style is the New Art Museum at Santa Fé. Recently completed, it is admired by all, architects and laymen alike. It embodies the designs of six of the ancient Spanish Missions, three centuries old, some of .which have now disappeared. The others are fast decaying with the ravages of time. The outlines of the Museum are plastic, smooth, and flowing, rising in curves and terraces, without stiffness, sharpness, or repetition. There is a noticeable lack of symmetry, contrasting so much with the style of the Californian Missions. Consequently, there is a different composition and an added charm with every new position or change of aspect. Inside are paintings and sketches of Indian, Mexican, and desert life and scenes, specimens of native handiwork, and an exhaustive library.

Across the road, on the opposite corner, is the Governor's Palace, the oldest governmental building in the States. Its appearance would in modern eyes hardly justify the term "Palace." It is a very unimposing building of native architecture but contains relics, trophies, and works of art brought from all corners of the Western world. Within its adobe walls are housed prehistoric remains of the extinct civilization that thousands of years ago thrived in Western America.

But not only the public buildings of Santa Fé are of Pueblo construction. Many of the latest private edifices, both residential and commercial, are of this strange architecture. The offices and works of the "Santa Fé Water and Light Company" give one the impression of its unique application to business buildings. But 


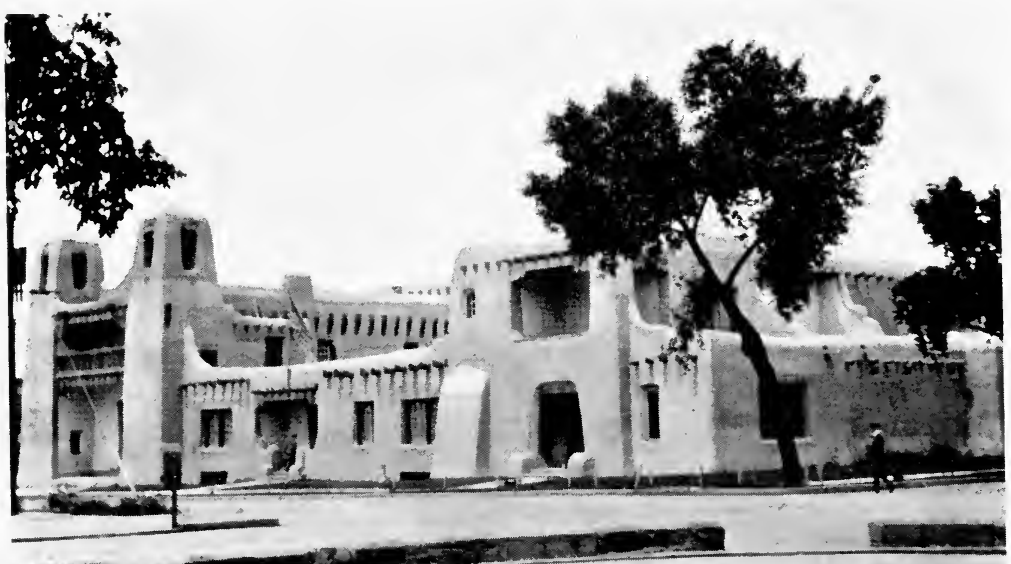

The Art Museun at Sarta Fé.

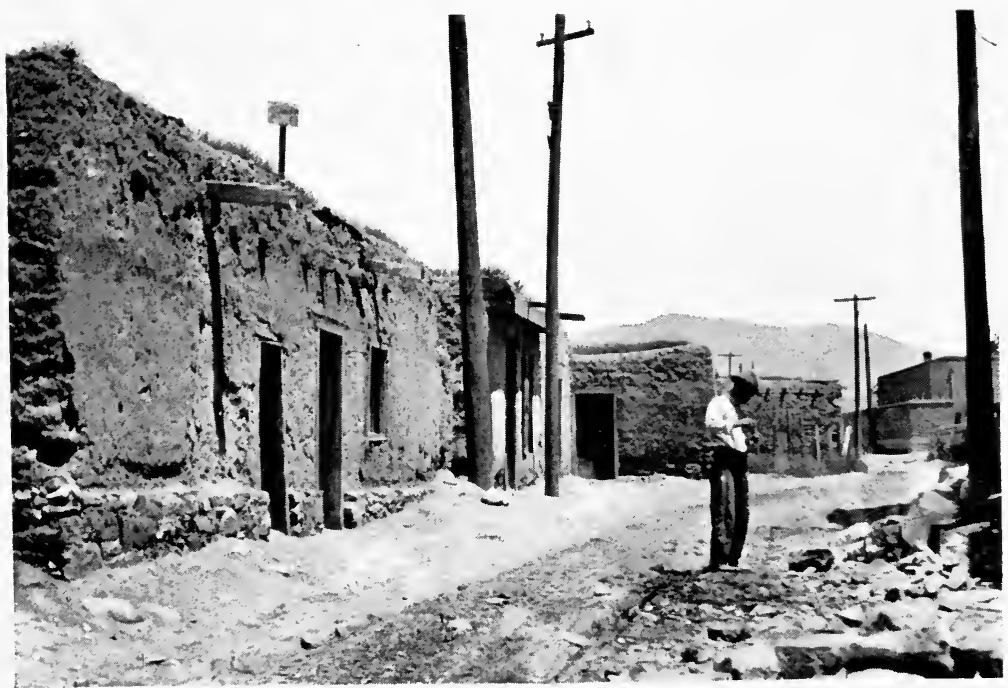

The Oldest House in America, at SaNta Fŕ. 

for sheer delight give me the private dwellings. It is beyond my power to convey an adequate impression of the soft beauty of one of these exquisitely-designed houses, with its smooth-flowing profiles, its shady " patio," open-air bathing pools and well-planned garden. One must go and see to understand and feel the charm of it all.

But from the Mexican houses as residences Heaven preserve me! Seldom do they boast more than one story; the roof is flat, and very often grass and weeds are found thriving thereon. The "adobe" walls are recovered from year to year throughout the ages as the hand of Time and the ravages of weather work their destructive way. It can almost be said that a Mexican house never grows old. The sun-baked mud that forms its walls withstands the weather to an extraordinary extent. There is a little house in a little street in the outskirts of Santa Fé, now uninhabited, from whose roof rises a notice-board: "This is the oldest house in America," it reads. It was supposed to have been built over 250 years ago.

The citizens of Santa Fé are not progressive. The climate is against them. They do not run any risk of over-exertion; a considerable time is spent in eating ices, drinking cold concoctions, and lounging about the plaza in the early hours of the afternoon. Here it was that I developed this Western habit. In almost every Western town there is a central square shaded with many trees, or palms in the hottest places. The good citizen and the weary traveller alike are welcome here. They lie about on the grass, or sit on their toes as only a Westerner knows how. Thus pass the blazing hours. It is a treat to find oneself away from the eternal hustle 
and bustle of city life and in the midst of languid, easygoing freedom. I had several photographs that I took to the drug-store to be developed and printed.

"Shall I call in to-night for them?" I said.

"To-night? Why, we won't be able to get them through for four days," he replied, amazed at my ridiculous presumption.

"But in New York they develop and print in one day only. Surely you're not behind New York?"

"Oh, we don't do things like that in this part of the country, friend; you've made a big mistake. Nobody hurries in New Mexico!"

By dint of special pleadings, I got the photographs in three days. They were nearly all ruined with having been hurried!

For three days I created quite a furore in Santa Fé. The news of my doings and misdoings was published daily in the Santa Fe New Mexican during my stay. I evidently afforded just the right kind of newspaper fodder that New Mexico wanted. My fame had spread all the way from Kansas City long before I actually fell upon the anxious population. My article on Roads, etc., was reproduced immediately after its publication in Kansas, together with several caustic editorial comments. Here is one example :-

\section{"SEES AMERICA BY COW-PATH."}

English Warrior gets little rest touring America by Motor-cycle.

"Roads? What roads? I haven't seen any roads. I have been following a place where cows had been walking. . . . "

Here is another heading to a two-column " article":-

"COW-PATHS"-and not roads in America :-Verdict of British Royal Airman here on Motor-cycle. 
And again (this headed a quarter-page "Report").

"BALLOON"-Only way to get over New Mexico roads, declares British Aviator.

I was pounced upon immediately after my arrival. No sooner was I settled down in a good steaming hot bath (oh, joy untold!) than the telephone bell in my room rang. I let it go on ringing for two or three minutes. It would not stop. I jumped out and lifted the receiver.

"A reporter is here to see you, sir."

"Och, Hell! Tell him I'm having a bath," and I banged the receiver down and plunged again into the tub.

In a minute there was a knock at the door. "No use trying to shake off an American reporter," I told myself. ... " Come in!"

The result appeared in next morning's paper-not the result of MY observations, be it noted, however. Amongst other statements the following was laid to my charge :-

"In my opinion the old Prairie-Schooner is far superior to a motor-car (for travelling in New Mexico). If you can't get a schooner, try horse-back travel. I really believe some horses could get through the mud and dodge the boulders. (It was almost funny there !) . . . But the ideal form of transportation over these United States is a big dirigible, say $700 \mathrm{ft}$. in length, modelled on Great Britain's R.34. (It had just recently crossed the Atlantic, hence the introduction.) ... I might have suggested the use of an aeroplane, but I have been told two aviators got stuck in Santa Fé last winter owing to the deep snow in the environs. So then, after seeing your roads, I should recommend the R.34 type of machine in which to travel. . . ."

Suffice it to say that I never mentioned PrairieSchooners, dirigibles, or aeroplanes! We talked (or rather our friend the reporter did) about the many notorieties that had passed through Santa Fé of recent 
154 ACROSS AMERICA BY MOTOR-CYCLE

years, and the Lowell Observatory at Flagstaff some 500 miles away.

Every day during my stay our friend the reporter called in at my hotel. Every day appeared in the press a lengthy report of an alleged interview.

What an interminable worry it must be to newspaper editors of the West to provide adequate copy for their hungering readers! 


\section{CHAPTER XVI}

\section{THE RIO GRANDE VALLEY}

My stay in Santa Fé was a pleasant one. At the Post Office I found a few letters and some money, the former forwarded from Cincinnati, and the latter from Washington (it had been cabled there two months before). On the morning of the fourth day my weary frame was sufficiently rested to warrant my continuing once more. I bought a two-gallon water-bag in preparation for the 700-mile desert journey ahead, and once more set out westward. A crowd of interested citizens witnessed my preparations outside the hotel, plied me with questions as to how far I was going, how long it would take, and how old I was, and finally bade me farewell as Lizzie burst into a roar, and we moved sadly, if noisily, away.

The next town was Albuquerque, some sixty or seventy miles ahead. The road in between lay over a barren wilderness of sand and prairie. The blazing sun poured down upon it fierce and unrelenting; nowhere was there a sign of any living thing. Hardly a hill or a swelling relieved the monotonous flatness of the trail. In the distance, on my right, rose rugged mountain ranges suddenly out of the trackless plains.

After twenty miles appeared La Bajada Hill, crossing the trail at right angles. There was not much climbing to be done, but going down the other side was a different matter. It seemed that a great "fault" or outcrop had 
appeared in the plain, making it much lower on the one side than the other. No less than thirty-two acute hairpin bends conducted the trail down the precipitous slope. The gradient in places was terrific. At the bottom was a cemetery!

Here and there we crossed the sandy wash of a one-time river, leaping over bumps and boulders and picking the road as well as possible. Occasionally a wooden shack was passed, with a few dirty-looking Indians hanging around: Indians dressed not in native garb but in pseudomodern style. The only things that betrayed them were their faces and lank dark hair. He that goes to the West and expects to see the landscape decorated with Indians dressed in multicoloured garbs of picturesque pattern, is doomed to disappointment. The first impression of a modernized native is disheartening if one has lingering thoughts in one's mind left from childhood's days when one read with ceaseless delight of stalwart Indians with huge muscles and painted bodies galloping along, bow and arrow in hand, on a fiery white mustang in pursuit of an unfortunate "pale-face."

Ah, no!-Nous avons change tout cela! The Indian as a rule is not stalwart, and decidedly not picturesque. Having had the gentle arts of civilization thrust upon him, and being naturally of a lazy disposition, he is content to loaf around chewing shag and disfiguring the landscape generally with his presence.

As Albuquerque was approached, things looked more flourishing. The land was cultivated where possible, and in places corn and wheat appeared.

It is very strange to find a prospering city in the midst of such desolate surroundings as Albuquerque has. It came as a pleasant surprise to me to see the electric trams, 
the wide streets and the clean modern buildings. I was puzzled to know just what it was that kept the place going. Albuquerque, however, although the largest town in the State, has only 10,000 or so inhabitants, and is the nucleus of a very extensive ranching district which undoubtedly largely constitutes its raison d'être. I left it rather sadly, because, with the exception of Flagstaff some 500 miles away, I should not meet another town of anywhere near its size until I reached the Pacific Coast.

Shortly after leaving Albuquerque the trail crossed a very wide shallow muddy river-the famous Rio Grande. It was spanned by a low wooden bridge which creaked and rattled in its planks as we rumbled across it. We saw quite a lot of the Rio Grande and got to look upon it as a friendly sort of river. That is not to be wondered at, because in a wilderness that is next to being called a desert one can become attached to anything that has life or movement, even if it be a muddy stream! Probably in consideration of the feelings of weary travellers, but for no other apparent purpose, the trail from time to time crossed and re-crossed the same old river with the same old friendly wooden bridges until finally, eighty miles farther on, it was left to wander southward unmolested through the plains and deserts of New Mexico and Texas into the Gulf of Mexico.

At Isleta there was a surprise in store. Isleta is a charming Indian pueblo, built wholly of "adobe" mud and populated entirely by native Indians. So unique, so bewitchingly attractive are these pueblos, that I must digress awhile to describe their nature and origin.

The history of the American Indians since the advent of the White Man is an unsatisfactory one from all points of view. Different authorities on the subject have widely 
different opinions as to the eventual outcome of the American domination, which from generation to generation has vacillated in its policy and, sometimes with bloodshed, sometimes with bribery, has gradually reduced the red man to subjection, occupied his country and enforced an unwilling civilization upon him. But all are agreed that the Indian of to-day is in a far lower stage of civilization than when the early settlers first drove him from his rightful property.

There are, however, a few tribes which advanced much farther along the road to civilization than the others. Moreover theirs was a civilization quite their own, not acquired through contact with the whites. Chief among them are the Pueblo (pueblo-building) Indians, and the Moqui Indians, the town-building natives of New Mexico and Arizona.

The "Pueblo" Indians include several different tribes, each speaking a different language. Each tribe, with only one exception, comprises a number of separate " pueblos" or villages, generally built on the " community dwelling" basis, that is, the houses are in a large and solid mass, several stories in height, each one receding from the one below and approached by ladders. In these houses, which look like great pyramids, live a number of families. In some pueblos most of the houses are on this plan and as many as 1,600 people have been known to live in one house. The houses are built of adobe, and sometimes of stones cemented together with adobe.

Several of these Indian villages are clustered together in the vicinity of Santa Fé, often on the banks of the Rio Grande. Each has its own customs and makes its own laws. All are centres of interest. Artists flock to them from all parts of the Continent to paint and sketch them. 


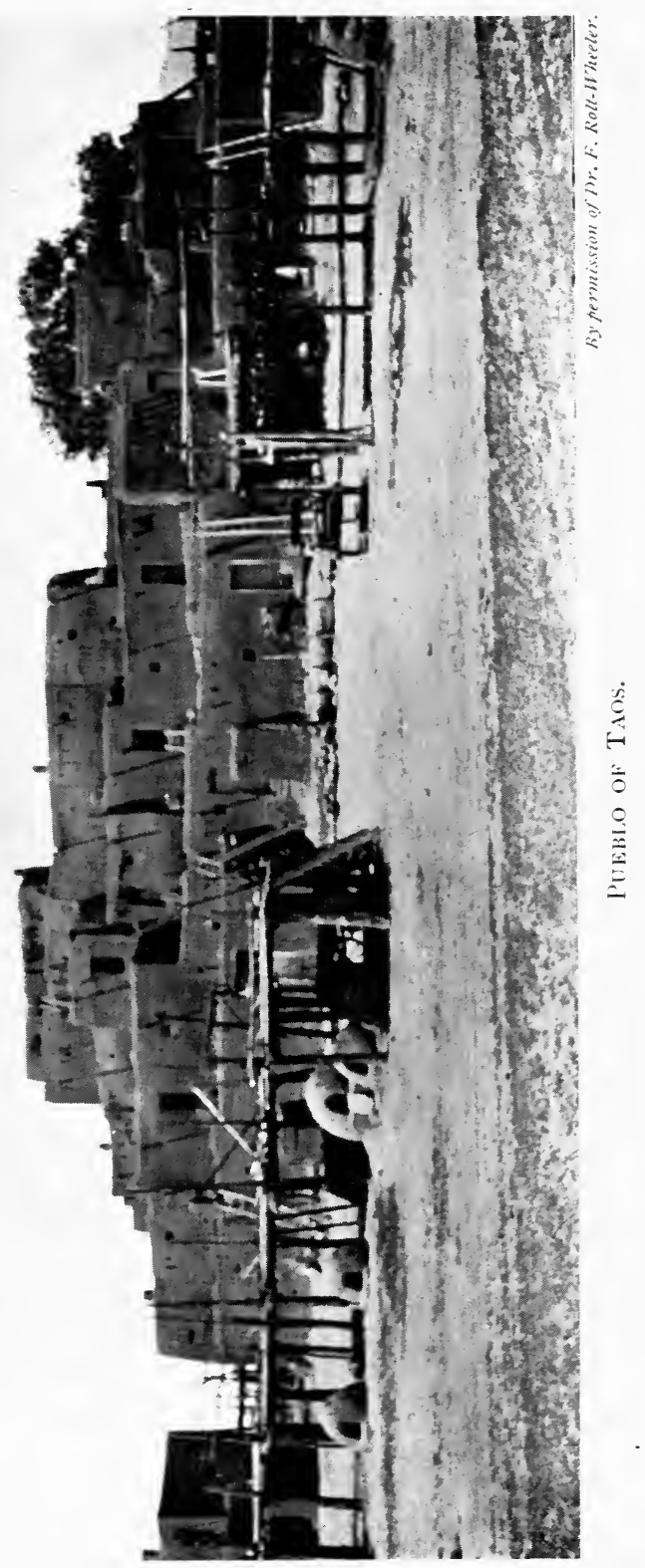



Travellers tramp for miles to see the Indians in their native costumes and conditions. Some make jewels; some make vases, ornaments, idols, and all manner of earthenware goods; some work in silver, while others make blankets and rugs. With hardly an exception they all make an excellent living out of the things they make and sell.

Each of the pueblos has its own feast-days, or "fiestas," when, for a time varying from a day to over a week, the whole population devotes its time to feasting, dancing and games. The religious rites that are performed and the strange customs that prevail at these feasts and dances form in themselves a vast and interesting study.

At Isleta the road again crossed the Rio Grande. This done, it found itself in a dry sandy wilderness, with the Manzano Range running from north to south in the distance. In patches the ground was white with sandhills, and the trail became two straggling white lines, where the wheels of passing vehicles had left their imprint in the soft white sand. These two white ruts were my only guides. All around was desolation. Nothing was to be seen anywhere, save those two thin white lines straggling aimlessly ahead, the sun-scorched desert with its ragged stones and evil, scanty, tenacious vegetation, and on the horizon that fiery stretch of mountain range, whose peaks rose rugged and defiant and glistened with red as if roused to anger by the eternally raging sun. I had never before realized the great depth of feeling that a mountain range is capable of evoking. The Alps are majestic beyond description. They awe the observer to a sense of his own utter insignificance as he gazes upon that glistening majestic sky-line, and feels the overwhelming influence of those mighty mountains upon him. 
But if it is an overwhelming influence, it is a friendly one-at least $I$ have found it so. Although there is an instinct in me, as in most people, impelling me to guard and protect myself against anything that is tremendousa relic, I suppose, of prehistoric days-I feel towards the Alps always like a little boy feels towards his " big brother." The same feeling is seen reflected in the "Sierra Madre" (Mother Mountains) of California.

But in New Mexico I have seen huge ranges that one could truthfully call nothing else but "wicked." They seem to gaze and glower with a cruel, terrifying gleam upon the wanderer who defies their hateful solitude.

The hours of travel that followed were hours of weary monotony. A brief lapse every thirty miles or so when a tiny Mexican village on the Rio Grande was passed, and once more the two white ruts came into view, the stones and cactus, and again the evil mountains.

Later, the sand turned to rocks. The trail began to climb the mountains, and the sun sank low in the sky. If ever there was a place to starve to death, thought $I$, it is here. I reflected upon what the consequences would be if I ran out of petrol or had a bad smash.

I didn't run out of petrol and I didn't have a smash. Instead of that, after about eighty miles from Isleta, the trail descended the mountain pass, re-crossed the Rio Grande for the last time, and swerved at right angles, to continue its course westward. Shortly before sunset I arrived at a little Mexican town called Socorro, where both man and machine were rested, while the man that kept the "C'fay" in the plaza got busy with some " eats" for weary me.

After dinner away once again we go. The sun is setting. We must find a resting-place before dark sets in, for in 
these countries where the air is clear and mountain ranges hem in every horizon the darkness comes quickly and the sinking of the sun below the sky-line means almost the final close of day.

There is another range to climb: it lies right ahead of us. As we approach, it looms its massive bulk like a wall before us. The trail bends and turns as if hesitating before it tackles this difficult feat; up there in front is a great gap. The road cuts through it, and is seen no more. Beyond are much greater heights to climb. Shall we attempt it now or leave it till the morrow?

The smell of petrol, which the last few minutes was a suggestion, became a reality. I look down in the fading light and find the precious fluid spurting out from the carburettor union. Evidently the pipe has broken away with the vibration. So I swerve off the road (almost easier done than said) and stop at the flattest patch of earth that I reach.

Oh, the joys of the open life once again! Never shall I forget that night in the desert past Socorro. The sun as it set behind the range that I had commenced to climb plunged everything around into gloomy blackness. Across the valley, from north to south, stretched the Manzano Range that I had already crossed. It shone like fire throughout the whole of its length. Gradually the rugged shadow of the range behind me crept farther and farther away, crossing the river and mounting up the opposite side of the valley. Slowly, slowly it mounted up, higher and higher as if a great black cloak were being drawn by an unseen hand over that fiery ridge that glistened in its evil splendour. In five short minutes there were but a few of the highest peaks remaining above the inky shadow. They enjoyed their splendour for a few brief 
moments and then were gone, as though wiped suddenly out of existence. All was blackness : silent, heavy blackness. The stars appeared, one by one.

I prepared my bed for the night.

What was that? A faint tinkle reached my ears. It sounded like the noise of a cow-bell, such as one hears in the Swiss valleys. Yes, there it was again. It must be a cow! But what was a cow to live on here? No doubt there was a well near by. I felt then that nothing in the world would taste better than a drink of pure fresh milk. The heat of the day had been intense, and one can always drink in New Mexico.

I slipped into my field-boots, took a collapsible cup from my bag and set out in search of the cow. I was quite determined to milk that cow, come what may.

I stumbled over the rough stones, picked my way between the cactus plants and sage-brush. I arrived at a fence. The tinkle, tinkle seemed to come from just the other side. Cup in hand, I climbed over, very gingerly so as not to tear my pyjamas. Pyjamas in a desert, think of it!

"Now, where are you ?" Ahead I saw dimly a large black form.

"Come along, girlie, come and be milked," quoth I in my most bewitching manner. She moved not. I advanced slowly, trying to discern which was the business end. Meanwhile I pictured the cow asking herself, "Wot's the big idea milking me in py's at this time o' night?"

I drew closer and looked. ...

It was a bull!

I returned hurriedly to my bed, and cursed when a prickly pear caught me on the left shin! 


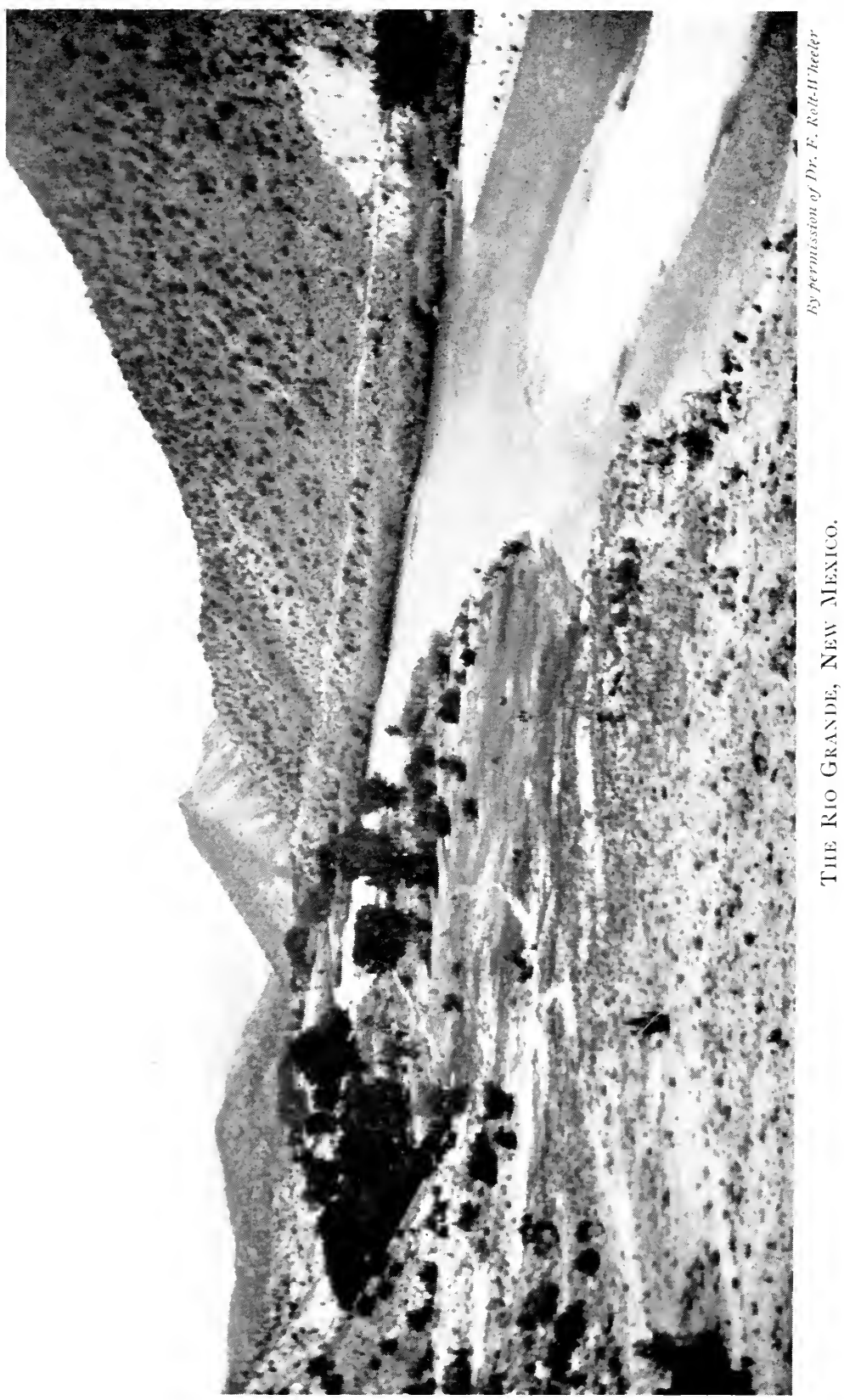





\section{CHAPTER XVII}

\section{THE PETRIFIED FOREST OF ARIZONA}

In the morning I patched up the broken petrol pipe as well as I could with insulation tape, and started again on my way. I had to do forty miles before I should see a soul-forty miles before breakfast could be thought of.

It was as well that I had stopped where I did the night before. The road twisted around precipitous bends and climbed up rough rocky slopes into the mountains. Down on the other side we found ourselves in a great sandy plain, stretching due west and bounded by parallel ranges of rugged mountains. There were frequent washouts and frequent spills. In places the little streamlets that flowed from the mountain sides cut great chasms across the road, sufficient to crush one's wheels if one leapt into them at too great a speed.

Magdalena is a typical cow-boy town. In the heart of ranching country and hundreds of miles from anything but a few similar towns, it was in the early days (before prohibition) one of the "warmest" places in the West. Cow-boy outfits are seen advertised at all of the few "Stores," but there has been one big change-the notorious saloons are no longer. New Mexico adopted prohibition several years before its universal approval. Consequently Magdalena had had ample time to settle down by the time of my arrival.

I was directed to a "C'fay" that had the reputation 
of providing the best meal in the town. I pushed open its swing doors and beheld a picture of cleanliness and tidiness. The tables were all spick and span in their clean white tablecloths and not a vestige of dirt was visible anywhere.

The small boys of the town displayed a lively interest in me as I disported myself with my camera at the expense of their public buildings (to be exact, one wooden church). "Look at 'is boots, Jem," said one. " Looks like as though he's a gor-dem buck-jumper." "Aye, but 'is pants don't look ter be the right stuff, Joe.".

I left them wondering and fell upon the trail once more. A few miles out I came to a " round-up " of steers. There were ten or twelve cow-boys on horseback, and some 5,000 or 6,000 steers grouped together in a large dense mass, blocking the road altogether. "Tough guys, those cowboys," I remarked to myself and pretended to ignore them. But I couldn't help thinking what mIGHT happen if I barged into one of their animals or if for any reason they didn't like the look of my face !

Slowly, very slowly, the great mass of cattle moved, like a tide sweeping over the plain. Carefully I picked my way along and felt relieved when I left them right behind. I opened out and prepared for a long weary jaunt. The next town of any kind was ninety miles away.

The first thirty were dead flat but hard going. There had evidently been considerable rain recently. Emaciated mud-holes were now rock-hard contortions in the road. Often I rode on the prairie in preference.

Another thing was evident. There had been a great drought the previous year. Ranching is impossible without water, and even now, in spite of the recent rains, could be seen here and there a great lake-bed completely dried 


\section{THE PETRIFIED FOREST OF ARIZONA 165}

up. Nothing remained but a great mass of sun-baked hoof-marked mud, and here and there a skeleton lying upon it. The ranches of New Mexico are of huge size and cover enormous areas. True, a few good years mean a fortune to the rancher, but one bad one means ruin. Hundreds of ranches had been ruined the previous year, I found, and several thousand head of cattle had died from the drought. As I passed along, their skeletons lay strewn at the roadside, sometimes singly, sometimes in groups of a dozen or more. Hardly a refreshing sight for a poor innocent motor-cyclist !

At the end of the thirty mile stretch we entered hilly, thickly-wooded country. The scenery was wild and rough. I met no one and saw no one. After another fifteen miles was a shack at the side of the road. The occupation of the owner was selling petrol and oil to passing travellers. I opined that this was probably not an enviable vocation from a financial point of view. I filled up, and found to my dismay that the price, instead of being twenty-five cents per gallon, was seventy-five. It was $\mathbf{1 0 0}$ miles from the railway, and all supplies had to be brought by road, hence the trebled cost.

I have never been through wilder country than that which followed for $\mathbf{1 0 0}$ miles. Hilly, densely-wooded, and fertile, it was most difficult to believe that it was so thinly populated. Strange rock-formations appeared. Grotesque boulders of leviathan size lay strewn and standing in grass-covered openings. Wild pigeons by the score darted in and out amongst the trees. Merry squirrels scampered up the pine trees and eyed me from above. Huge "Jack Rabbits" and young antelopes bounded here and there, and, seeing the intruder, disappeared. It all seemed such a change from the desert journey of the day before. 
At Quemado, about ninety miles from Magdalena, I felt hungry. Quemado consists of a wooden shack of an "hotel," and one "general merchandise" store. I stopped at the "hotel" and fed. Meanwhile it commenced to rain. My spirits sank with the barometer.

The rain stopped three hours afterwards.

I set out full of energy and perseverance an hour after that. We slipped and slithered and slid in the miry road. Ten miles was enough. All the energy and perseverance had flown to the winds. I rode up on to a hill-side to a spot on the fringe of a forest of cedar and yew. Propping Lizzie up on her stand, I went in search of fuel. I had decided on the luxury of a camp fire.

Fuel there was in abundance. Withered trunks and broken boughs lay strewn about the hill-side. I soon had a roaring fire and passed away an hour or two before dark in writing letters and ruminating on the delights of a camp fire.

As the sun sank down in the valley, I slipped under the old blanket and watched the flames as they leapt from the burning embers. Just ahead, almost in sight from where I lay, was the western borderline of New Mexico. Just beyond there, where the golden sun was slowly sinking in the valley, was Arizona; the Arizona that I longed so much to see. I had heard much of Arizona ; its wonderful climate, its ancient, unknown ruins, its extinct volcanoes, its stupendous gorges, its great thirsty deserts. What would Arizona have in store for me? I wondered. And the fragrant smell of the burning cedarwood wove a magic charm about my thoughts as they slowly drifted into the mystic realm of the unconscious world.

Morning brought a smiling dawn. I rose early and returned to the trail. 
In ten minutes I was in Arizona. A large signboard indicated the fact. The road grew wider and better. Even the scenery seemed to change perceptibly. I somehow felt at home in Arizona.

At Springerville I breakfasted and bought picture postcards. When travelling the latter operation is equally as important as the former.

Here the road makes a sudden turn to the north, bearing afterwards to the north-west. After twenty miles of riding, the country became flatter; it seemed as though it were now an immense plateau. After another twenty, I reached a little town known as St. John. Here I filled a half-hour in the commendable process of consuming ices. I had now to traverse some difficult country, as the great desert of Arizona was approached. There were more mountains to climb, but when the summit was reached there was little or no decline on the opposite side, the altitude grew higher and higher, and as it did so, strange as it may seem, the earth grew flatter and flatter.

There is but one ridge ahead to climb. The rocky trail bends and twists as it slowly swallows up the gradient that connects us to the horizon. A final swerve, and we commence a slight descent. There is a gap in the hills; the trail skirts around one side, and behold, a vast, unbounded plain lies before us, stretching to left and right as far as the eye can see.

But what is this strange sight? On our right, barely a half of a mile from the road, is a gigantic mound. Its presence there, rising abruptly out of the mathematical flatness of the plain, seems ridiculous, absurd, uncanny. It gives the impression of having been just dropped from the sky. It is a mud volcano-an uncommon sight, and formed by the ejection of sand under pressure from below 
the surface of the earth. All around, the plain is of distinctly volcanic formation. Indeed, we have now entered a vast volcanic region, extending for several thousands of square miles. Many of the mountains that we shall see, some of them giant peaks, and some only little hills, are extinct volcanoes of other ages. They were young and active while man was in his barbaric infancy on this weary globe, perhaps even before that.

But soon is to appear a far more wondrous sight. In a few miles we enter a country of strange shapes and magic colours-the Petrified Forest of Arizona. The first signs of approach are chains of little lava hills of grey and white. They also have an air of abruptness. One wonders how they came to be there at all. Flowing down to the flat plain in graceful, mathematical curves, they look like mounds of chalk, although they are softer still. Composed of soft, fine lava-dust, they weather rapidly away. Now all the plain is lava-dust and a tuft of lean grass here and there has found a spot wherein to make a home. Further on one notices great blocks of stone, like pillars of marble, lying strewn about the plain, some half buried, some barely projecting, and some perfectly naked. Her€ is one, there is another-they are everywhere, in every direction, of all shades of eolour and varying in size from fragments an inch in diameter to pillars twenty or thirty fect in girth and over 100 feet in length. Every fragment, every massive block of marble once formed part of a great forest that spread for hundreds of square miles. The trees of this great forest were huge leviathans, unlike anything we know of in the Old World and similar only to the giant Sequoias of California (but a few hundred miles away), that send their mighty trunks hundreds of feet into the air-the relics of a bygone race. 
This great forest of Arizona was at its prime. The stately pine trees rose towering into the sky. Birds of wonderful plumage lived in those mighty branches, and wild animals roamed amongst its undergrowth. Then something happened; no one knows exactly what-this great forest was enveloped in volcanic dust that in time buried it completely. To the eye, if eye there was to witness the scene, the forest was no longer visible; it lay buried in the bowels of the earth ; it had passed away; as a mighty, living forest it would exist no more. But those monster trees remained awhile, preserved by the allsurrounding lava. What happened then took thousands of years to achieve, though it can be recited in a few brief words. The trees in substance disappeared, but their forms remained in the hardened lava, like huge moulds waiting to be cast, their every crack and wrinkle preserved with inexorable accuracy. In time, it may have been æons, the moulds were cast, by some inexplicable phenomenon, and where once were timber and vegetable tissues came fluid marble rock that filled the hollows and cracks and wrinkles and reproduced the forms that ages before had been so suddenly arrested in their growth. Further ages passed, and gradually the soft lava was removed by the action of wind and rain and other causes. Gradually the harder material was laid bare, and the giant trees once more saw the light of day, but this time they were trunks of solid marble instead of pine wood. The work of denudation continued. The marble pillars, unsupported, fell to earth. Some broke into huge blocks, while others remained more or less intact through the whole of their length, and unless one examined them at close quarters and saw the nature of their texture, they could not be distinguished from a tree that had been recently felled. 
There are hundreds of these marble pine and spruce tree trunks, whose cross-sections, revealed where they have broken, glisten with every colour of the rainbow. In places, where they lie tumbled and heaped together, it is as though a whole quarry of onyx had been dynamited out. In one place a fallen trunk of marble, nearly 200 feet in length, has spanned a gorge and formed a natural log bridge that all who dare can walk across.

Such is the fairy tale that scientists tell. The traveller whose privilege it is to journey across the Petrified Forest of Arizona will be lost in amazement at this fact which is so much stranger than any fiction.

I left the wonderful scene behind me with a feeling that I was bidding farewell to one of the prime mysteries of the world. Trunks and fragments of trunks could be seen projecting even from the surface of the road over which I passed, and a few blades of fine grass, with here and there a stunted cactus plant, were the only sign of life in any dírection. I passed out as suddenly as I had entered. A double S-bend, where strange contorted rocks lay piled up in confusion on either side-and the Petrified Forest was left behind.

The sun was nearly setting when a couple of hours later I set out from Holbrook, well fed and well refreshed. From my map I judged I should be able to reach the Little Colorado River, on whose banks I could spend the night. But in Arizona the sun sets quickly. It can almost be said to get dark with a bump. The result was that in half an hour I was completely lost in the outskirts of the Great Arizona Desert. The trail had somehow disappeared, I knew not where, and but for my headlight, I should undoubtedly have ended in difficulties amid the inky blackness. Loth to turn back, I continued over the 


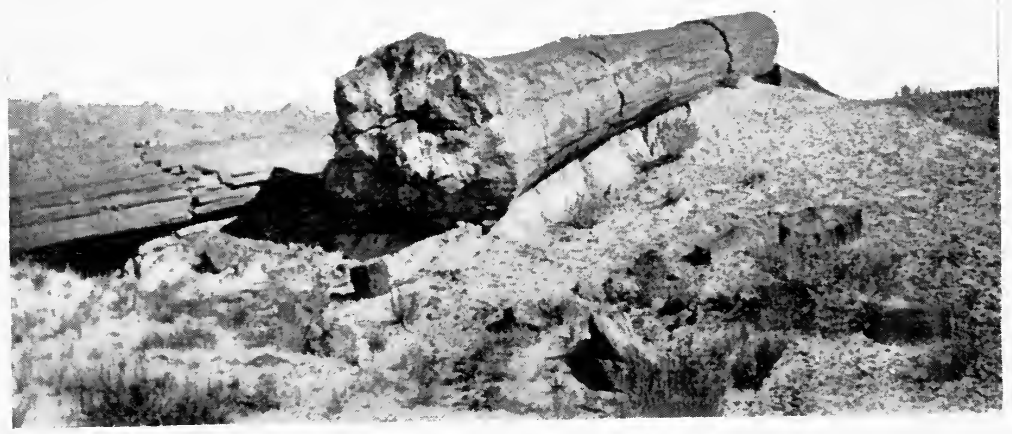

A Petrifien Leviathax.

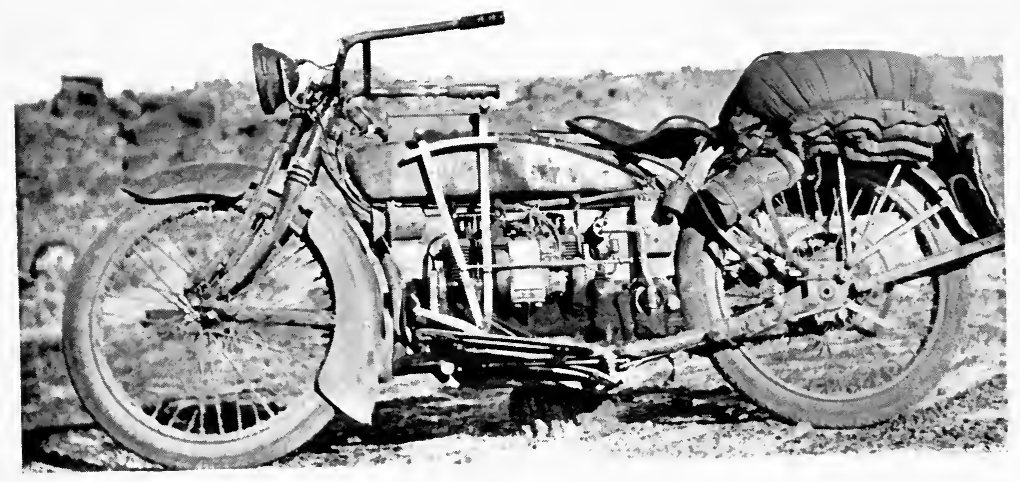

"Lizzie" in the Petrifien Forest, Arizona. 



\section{THE PETRIFIED FOREST OF ARIZONA 171}

almost trackless waste of rock, sand, and prairie. I arrived at the rocky bed of a small stream. There were a few inches of water here and there, but it was not perceptibly moving. It could not possibly be the Little Colorado. I walked across to the other side. There I found a large ditch, more like an artificial dyke, that I knew I could never get Lizzie across. There was grass growing near, however, so I laid down my bed for the night, resolving to leave further investigations till daylight.

I should have known better than to camp by an almost stagnant stream, but I was so utterly tired that I defied the counsel of my own experience. Mosquitoes literally filled the air. Never have I known them so thick and so tenacious. The vibration of millions of wings kept the air in a constant shriek-a wild yell that never abated. I could only obtain relief from their attacks by enveloping my face completely with the thick blanket, and breathing through it. Then everything became so hot-the night itself was very sultry-that sleep was next to impossible. I snatched an hour or two of rest, but was a mass of bites and itching lumps next day.

In the morning, I returned to Holbrook, had breakfast, and searched for information about the road. It appeared that a bridge had collapsed somewhere, so a new trail had been formed to circumvent it. I had missed the turning the night before. At the garage where I made these inquiries, I took the opportunity of removing Lizzie's wheels, and of cleaning and adjusting the spindles. I packed them with new grease in preparation for the sandy journey to come, and removed and re-aligned the chain sprockets; I wanted no breakdowns or searches for missing parts in the baking, sandy desert. It was as well that I had taken precautions. I found the lock ring of one chain 
wheel missing altogether, and the sprocket half-way unscrewed from its shaft. The only item for regret was the charge of one dollar for the use of the garage! Having already had experience of American garage mechanics, I resolved not to allow any more to learn their trade at Lizzie's expense.

I had no difficulty in picking up the trail in the full light of day. Once again I set out to cross the great Desert of Arizona. The next town, a kind of oasis, was Winslow, about forty miles away. The barren prairie soon gave way to bare limestone rocks and shifting sand; vegetation disappeared altogether, save for occasional clumps of greeny-grey sage brush dotted here and there over the rocky waste that ever met the eye. The air was hot but clear. On an elevation one could see for tremendous distances. The little tuft of black smoke that hung over Winslow looked clear enough to be a mile or two away. It was thirty; in the distance was a great silver line, threading its way intermittently across the plain. I knew it to be the Little Colorado, which, like its mother, the Great Colorado, flows nearly the whole of its length in a canyon and seems deliberately to choose the path of greatest resistance, cutting through rocks and gorges of limestone and granite with ne'er a murmur.

As Winslow drew near, the narrow sandy track gave way to a broad concrete highway. I had not seen a made road of any description for many days. The appearance of concrete here in the middle of a desert seemed ridiculous. I would enjoy it to the full. Lizzie's throttle jumped open unexpectedly and away we sailed through the breeze. "There's a catch in this somewhere," I told myself. There was! It nearly meant grief. The city architect had foreseen the goading lure of that cold flat stretch of 


\section{THE PETRIFIED FOREST OF ARIZONA 173}

concrete and made up his mind that speeding should not exist thereon. So he made several dips therein at intervals, each dip about five or ten feet below the normal level of the road. Any attempt to travel at more than twenty would mean damage to the vehicle when it hit the opposite side. Unfortunately these obstructions were absolutely invisible until but a few feet ahead. Sometimes there was a warning. More often there was not. The first I came to quite unawares and at a high speed. The machine with its momentum nearly leapt clean across the space, and had I been going much slower it would have struck the opposite side lower down and inevitably have caused a serious crash. I went warily after that and wondered what ingeniously contrived anti-speeding devices I should meet next.

Arrived at Winslow, I ate heartily of ices. The busy modern town seemed a most remarkable contrast to the sandy wastes that surrounded it.

I now had a long journey ahead. Flagstaff, the next town, was over eighty miles away, and the trail ran across some of the most arid country of Arizona. For mile upon mile there was nothing to be seen but yellow sand and, on the horizon, a rugged range of hills. Ahead, nearly a hundred miles away, loomed up the San Francisco Peaks, dark and threatening. Overhead the sun beat down with unrelenting fury. One could see the shimmer of the air above the baking sand as the tremendous heat oozed out of it into the atmosphere. Here and there, one could see spirals of sand hundreds of feet high whisked up by some strange whirling motion of the air, and carried for hundreds of yards across the wilderness, gathering in volume and height as they moved, only to collapse again and give birth to others. Not a sign of life or vegetation 
was visible anywhere. What a place to be stranded in without water! But I had plenty with me. I stopped to drink from the bag on my handlebar every few miles. The heat and the glare were awful.

A few miles out of Winslow one cylinder ceased to fire. I had been wondering when the next instalment of misfortune was to arrive. Like a true pessimist, I expected it would come in a place like this. So I was not disheartened.

I stopped two or three times to change plugs and examine the engine. It was of no avail, and the heat grew so intense when I was not moving that it was impossible to stop for longer than a few minutes at a time. There was no shade, not even a rock to hide me from the fiery sun. The frame of the machine seemed red-hot, and even the tools in the tool-box were too hot to handle unprotected.

"Another overhaul at Flagstaff," I told myself, and continued again on three cylinders. Ploughing through the loose sand absorbed much of the power of the engine, but I was content, so long as we kept moving. Slowly the metal sign-posts of the "Touring Club of California" that marked the miles were passed. They were the only items of interest in this barren country. Many times they were missing altogether. Often they lay prone upon the ground, the strong, eight-feet-long steel tubing of the post bent in strange forms. They had been uprooted by some unfortunate traveller and used as levers or crowbars to extricate a car that had left the beaten track and sunk in the loose sand of the desert. Some even bore conflicting particulars, and it was quite usual to notice the distances increase instead of decrease the nearer one drew to one's destination! Often the signs themselves had been riddled with bullet-holes "just for fun" by some blasé traveller with a taste for shooting. Splendid 
amusement, to shoot at a sign-post put there at enormous expense by a private club for the benefit of all !

Slowly the hours went by and, as they did, a huge thunder-storm could be seen brewing over the San Francisco Peaks, now only forty miles away. The whole sky became dull and overcast. The loose yellow sand gave place to rocks and shingle, and gradually the desert was left behind. As the altitude increased-we were climbing slowly all the time-signs of life appeared. Lean grass, parched with thirst and brown with the heat, was seen once more, and later a few sheep were noticed sheltering behind rocks and boulders.

I pushed forward with all haste. Flagstaff was at the foot of the San Francisco Peaks and there would certainly be a deluge very shortly. The road was abominable. In most places it was so rocky and the gradient so steep that it was like riding up great flights of rugged steps. The sharp rocks dug in the tyres down to the rims, and the vibration shook the very sockets of one's bones.

On the left, barely a mile from the trail, we passed the "Meteor Mountain." This is a most remarkable sight. Situated in the midst of comparatively flat or rolling country, it looks at first sight like the crater of a great volcano. But its origin is not volcanic. It gives the impression of having been formed by artificial and not by natural means. The crater is half a mile across and the interior of the crater is saucer-shaped. An air of mystery envelops its origin, and many theories have been put forward to explain it. But the theories have either been disproved or have never been definitely accepted.

"Meteor Mountain" remains to this day a mystery of geology. In its crater is a ranch-house and hundreds of sheep graze in its vicinity. 
A dozen miles farther on the trail led on to a magnificent steel bridge spanning the "Diablo Canyon"-a wonderful gorge in the limestone rocks. Far, far below ran a little stream of clear water.

The sky grew blacker still. We continued climbing over the sharp, rocky trail. The mighty peaks ahead were almost lost in a sea of blackness. Distant thunder rumbled and groaned across the desolate waste. Sharp flashes of lightning lit up the heavens for a moment and revealed the sharp, lurid outlines of the three giants around whose peaks centred the fury of the skies. Slowly the storm abated. I thanked Heaven for that.

Then we came to the fringe of a wonderful forest that covers the plateau and clothes the mountain sides almost to the summit of their peaks. The sight of the trees, the sound of the breezes as they rustled through the branches bearing with them the magic scent of the pines, was like passing from death to life. It was a new world, a world of new sensations and pleasant forms. The broiling wastes, the dazzling yellow sand, the strange and sometimes ugly shapes, the grotesque, the mysterious, the incredible: these were left behind-for a while.

The storm had almost passed. Much rain had fallen, but fortunately the trail lay through a stretch of volcanic dust. The rain when it fell did not dissolve it, but soaked through as quickly as it fell, leaving the surface almost as hard and dry as it was before. I thanked Heaven again for that. Closer, closer, ever we climbed, until often the mountains were hardly to be seen; we were amongst them, climbing them, in them. Here and there the clustering trees grew thinner and fields of wild flowers, mauve and purple-coloured, would burst into view, clothing the valleys and the slopes like a great carpet. 


\section{THE PETRIFIED FOREST OF ARIZONA 177}

Then a glade would appear of fresh green grass-grass so fresh and so green that it would seem to have been meant more for a child's fairy-book than for a real live world. Then a beautiful mountain would appear through the trees, its sides and its angles glistening with every colour of the rainbow and changing with every new aspect. This would be an extinct volcanic cone and the colours would be reflected from the loose cinders that formed its whole. Then amongst the lofty pine trees the traveller would see-as a last remnant of the grotesque-vast fields of lava, great beds of solid cinder, thrown up into monstrous shapes with strange, sinister outlines. And onwards, ever onwards, ever nearer to Flagstaff we went, the wheels gliding noiselessly over the smooth lava-track that wound its way in and out of the pine trees and up and over the foothills and valleys towards the West. We enter a large valley, from which a wonderful view of the San Francisco Peaks delights the traveller. They are barely a half-dozen miles away now ; their great volcanic cones, over a couple of miles in height above the sea, can be seen as sharply and as clearly as though they were but 100 yards away. So mighty are they, and so pure is the air of Arizona, that on a clear day they can be seen for 200 miles in any direction.

At last the small town of Flagstaff is reached. It is clean, modern, and laid out in pretentious square blocks, some with only a few bungalows built thereon. Evening was drawing on. Not having had a meal for over twelve hours, I hied me to a restaurant where puffed cereals and apricot pies and mugs of good coffee effected a miraculous disappearance. Thereafter I followed the scent of a comfortable hotel, where once more I slept the sleep of the righteous. 


\section{CHAPTER XVIII \\ THE GRAND CANYON}

I woke up next morning feeling very groggy, for no reason accountable to myself. It was Sunday. My first endeavour would be to fulfil one of the desires of my boyhood. It lay at my very door.

The Lowell Observatory at Flagstaff is known throughout the whole of the civilized world. Years ago, hundreds and thousands of people read with unabated interest of the theories and discoveries of Professor Lowell concerning the planet Mars. In his book, Mars and its Canals, he recorded the researches of a lifetime on this most interesting of planets. $\mathrm{He}$ announced his conviction that civilized life of a very high order was present and flourishing on Mars, and supported his theory with exhaustive data and series of beautiful photographs of the planet at different times and under different aspects-the result of the work carried out at the Lowell Observatory which he himself had founded, built, and maintained at his own expense.

In my boyhood's days that book read like a wonderful fairy story, illustrated with photographs that were far more wonderful and far more strange than the merely pretty pictures of fancy. Some day, I promised myself, I would see the Lowell Observatory, and look through the giant telescope that revealed to the human eye, millions of miles away, so much of the mysterious and the unknown. 


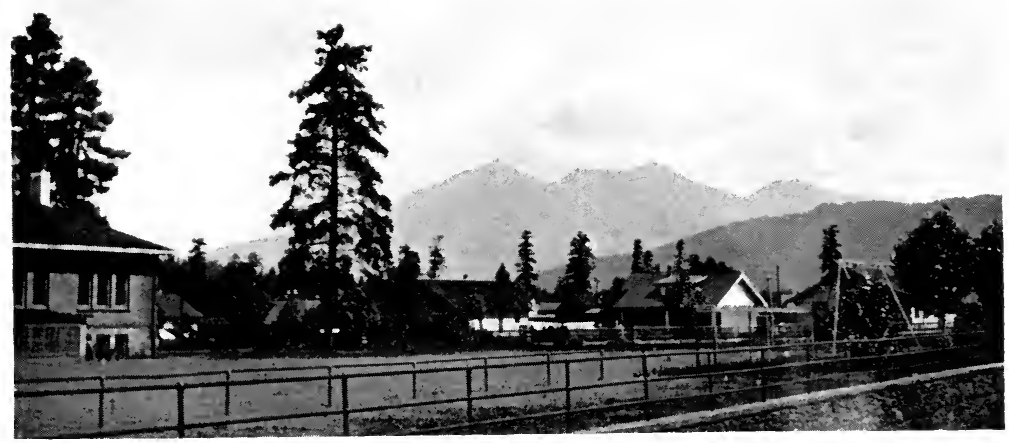

SAN Fraxclsco PEAKS FroM FIAGSAFF.

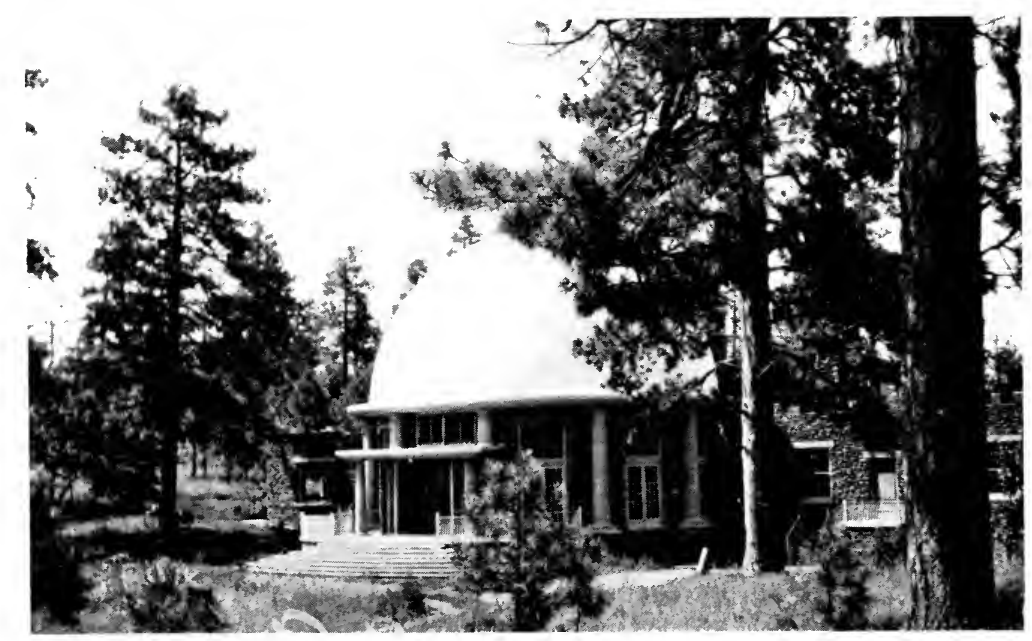

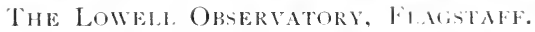

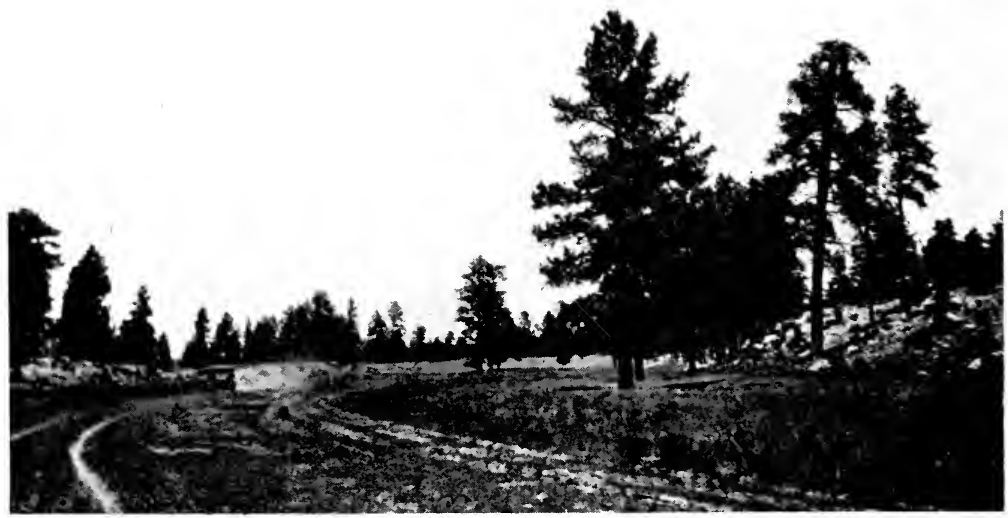



And here I stood, at the door of the hotel, but a few hundred yards from that same Observatory. Looking up the main street I could plainly see the white dome, perched on the summit of a hill overlooking the town, surrounded, but unobscured, by the tall pine trees that clustered thickly on its slopes.

An hour later I was standing inside the great dome. The dream had come true.

The astronomers of "Mars Hill" treated me, like all visitors, with the utmost hospitality. My wishes to see this and that and the other thing had only to be expressed, and they were granted. I was shown the result of years upon years of tireless, ceaseless research. In the library, a magnificently designed and equipped building, I found myself in a veritable Monte Cristo's cave. Arranged around the walls, and lit from behind by a wonderful system of electric lights, were treasures of far more value than would appear to the casual, disinterested sightseer. There were transparent photographs of planets, star clusters, nebulæ, and comets by the hundred, some but a fraction of an inch in diameter, and others several feet across. There were volumes of records and reports of every Observatory, besides astronomical and other scientific works of all classes, sizes, and tongues.

Hours afterwards I slowly descended the path that wound down the hill-side through the pine trees, wrapped in thought and proudly conscious of having at last achieved something that for so long had been but a vague vision of the imagination.

Unfortunately my indisposition of the morning did not disappear. It increased. I surmised that somewhere or other I had drunk some poisoned water-an easy thing to do-and must suffer the consequences. 
The consequences I suffered were those of ptomaine poisoning. The next day was spent in the throes of it. I crept out of bed for an hour or two, with just enough courage to visit the garage to whose charge $I$ had confined Lizzie for an overhaul. Finding her once again in pieces, but with no parts broken, I returned, with a sigh of relief and a body full of pains, to bed. I had discovered that many patrons of a certain restaurant-the one which I had so heartily greeted upon my arrival-had also suffered from ptomaine poisoning. I reflected that this was an ailment that often proved fatal. But I determined that it would not be so in my case, at any rate not until Lizzie and I had gazed down on the deep blue waters of the Pacific Ocean. That accomplished, anything could happen!

The next day found things much brighter. The sickness was fast disappearing, and I was consoled towards midday by the sight of Lizzie erected, tested, and passed O.K. I was, however, sceptical of the youth to whom, in my indisposition, I had entrusted her delicate body. He had sworn that he had overhauled Hendersons until he could do them blindfold. With characteristic American modesty he claimed to be the only man between Kansas City and Los Angeles who knew anything at all about the breed. That made me a trifle suspicious at the outset. Furthermore, he had agreed to turn in on Sunday and commence operations, but when Sunday came he was hardly conspicuous by his presence-the garage door was locked.

However, I paid over the required quota of dollars with Spartan stoicism and took Lizzie once more unto my bosom. Being naturally of a lazy disposition and a firm believer in the futility of walking whenever there 
is the remotest opportunity of some form of mechanical transit being available, I had deferred an extensive survey of the town until I could execute it in comfort.

Originally a stores depot on the early trail through the West, Flagstaff soon became a ranching centre and a kind of "Mecca" for cowboys, globe-trotters, wasters, drifters, Indians, Mexicans, and, of late years, speculators and East-weary business men. Although boasting only a few thousand inhabitants, the town is growing fast, and naturally where towns grow fast-a thing known only in the west of America and the Colonies-the "real estate" agents flourish in their legions. The people of Flagstaff are "boosters," and so do all they can to encourage and quicken the growth of their neat little town. Many come there, buy a plot of land in one of the outlying blocks, build a bungalow and settle down for good, charmed with the climate, the atmosphere, the surroundings, the great pine forests, and the view to the north of the mighty Peaks that are almost always capped with snow and seem to look down and protect the little town that lies scattered at their feet.

Next morning I had concluded all preparations for the fulfilment of another life-long desire. My next ambition was to see the Grand Canyon of the Colorado, of which I had read much in school-books in my childhood.

In and out through the pine trees we swung once again, darting down sudden dips in the road and skipping up little hills all fresh with grass and thick wild flowers. In ten or fifteen miles of exquisite woodland scenery we had come once more to the fringe of the forest. Ahead lay plain, prairie, and desert, with never a town or a village or a house to be seen until the Canyon was reached 


\section{2}

\section{ACROSS AMERICA BY MOTOR-CYCLE}

seventy odd miles to the north. On the left rose the great San Francisco Peaks, clothed in green and white. On the right lay Sunset Mountain, a volcanic cinder cone of ruddy-brown hue, that glistened in the morning sunlight.

Slowly they were left behind as we hopped, skipped, and jumped over the rough trail that swerved and twisted untiringly through the strangest country imaginable. Here it would be broad and sandy; there it would narrow down almost to nothing; further on, it would make a sudden bend and dip across a "wash" or some waterless river that had never known a bridge; then it would enter a beautiful valley all aglow with golden flowers that crowded thickly up its sides-there were yellow flowers everywhere, in each direction as far as the eye could see, and at the same time so close that they were swept aside by the machine as it passed. Then that picture passed away and there remained just two deep undulating ruts that struggled persistently across a wilderness of sand, rock, and boulder. We passed on either side the remains of ancient volcanoes, now but solitary hills rising abruptly from the desert around. Then appeared giant heaps of stone clustered strangely together, the ruins of ancient towns for many a thousand years deserted. Then for miles and miles was nothing but barren, arid waste that tired one's patience and cut one's tyres and shook one's limbs, while thousands upon thousands of prairie-dogs were ever running, hurrying, scurrying away from the intruder upon their solitude. Their holes were everywhere, even in the ruts of the trail that stretched always like a forgotten, lifeless thing through this land of scorching loneliness. 
Four hours and a half we had now been travelling, and not a soul, not even a sign of a living being had we seen, save the merry little vermin that scurried off at the sound and the sight of us. For the first time in the whole of the trip I felt a great sense of loneliness creeping over me. The solitude, the peace of the great barren distances at last made itself known-it was a solitude and a peace that $I$ had never felt before. It took time for me to appreciate its worth. I amused myself by bursting suddenly into song. All the old familiar refrains came to my aid, were they hymn tunes or ridiculous rag-time airs.

Feeling absurd-even positively ridiculous-in my efforts to remain cheerful at all costs, but comforted by the thought that there was no one to witness my insanity, I continued thus until my voice rebelled and I relapsed once again into stony-very stony-silence!

Once again the trail entered a great forest; huge pine trees and cedar trees closed densely around and the trail branched and split here and there to avoid them. The vegetation grew thicker. It seemed wonderful how it could possibly thrive in such a country. Not a drop of water had I seen for eighty miles, when suddenly a most beautiful vista appeared directly ahead of me. There was a wonderful lake bordered with giant pine trees, its waters still and flat like a great jewel. At its edge a few horses were drinking. It was such a magnificent sight that I was forced to stop to admire it to the full. I breathed a prayer that my little pocket camera would do it justice, and convey, if only a fraction, some of that entrancing charm that hung over its glassy waters.

On once again we rode, through avenues of pine and cedar ; the further we went, the thicker the forest grew 
and the greater the stately trecs became. It was possible only to see a few yards ahead in some places.... "But say, we must be getting near the Canyon soon! How can all this be?" I asked myself.

Swerving now to the right, now to the left, to avoid some obstacle, now leaving the trail altogether to ride on the soft green grass at the side, when a boulder or a fallen branch blocked the way, it was like exploring one of those magic forests where fairies ...

The thought was never finished.

It seemed as if the whole earth had suddenly stopped dead. There, in front, the great tree trunks stood silhouetted against space itself. It was as though something dreadful had happened. Beyond was tremendous, awful nothingness that made the observer catch his breath and sent a shiver throughout his frame. But see, there, on the distant horizon, like a dimly-coloured shadow, lies the opposite side of the gigantic rift, ten, twenty-aye, in places thirty miles away. It is a sight to enjoy in silence, with reverence and with fear. Once seen, it is never to be forgotten, that first glimpse of the greatest of all natural wonders-the Grand Canyon of the Colorado.

The trail made a sudden swerve to the left and followed close to its brink. There were some wooden railings; beyond, a varying strip of broken, rocky moorland; and then, space. Leaving Lizzie, I clambered down a narrow pathway carved in the rocks that led to a jutting prominence known as "Grand View Point." Seated on a huge lump of limestone that reared like a lofty pinnacle thousands of feet above the chasm below, I surveyed in mute bewilderment the overpowering, aweinspiring sight. 
The Grand Canyon has never been described. It is too immense, too sublime, too unearthly for mere words to convey one iota of its might and majesty. One struggles with the futility of mere expression by words where such a spectacle is concerned and finds that all the known phrases and well-used artifices of speech are useless to convey to another the sense of infinite grandeur that only sight can appreciate-and that so feebly!

The Canyon is a titanic rift in the earth, over 200 miles in length. The Colorado River, hardly ever seen from its brinks, lies 6,000 feet below the surface of the plain through which it has cut. Eons of time have been taken in the making of it, and it is yet but young, its progress still continuing. That sinister river, to reach which takes a seven-mile walk down the trail that leads to its waters, has cut down through strata of rock that took untold millions of years to be deposited, has cut lower and lower until it has come to the very beginning, the foundation of the earth, and then it has carved its way even through the granite, the very crust of the earth, to a depth of almost 1,000 feet. Eternal erosion by water, winds, and frost has helped it to play its part, and now nigh on 2,000 cubic miles of limestone, sandstone, and granite have disappeared entirely-all carried as sediment into the Pacific Ocean by the river that for ever swirls and rages in its bosom.

The actual settlement that goes by the name of the Grand Canyon is twenty miles further on. The trail follows closely the rim of the Canyon, cutting through the fringe of the "Coconino National Forest," with its stately pine trees that crowd up to the very edge of the plateau.

When the end of the trail is reached, it is as though 
the traveller had arrived at the edge of the world. On the right is a luxurious, low-built hotel all but toppling over the edge ; on the left is a railway station; and that is all. The road almost doubles back on itself, swerving due south towards the Continental Trail eighty miles away. I do not mean to imply that at the end of this world there will be either a luxurious hotel or a railway station at the service of the weary traveller, but the appearance of finality of all things is complete when one is faced with that terrible chasm ahead.

For three days and three nights I sojourned at the Canyon, content to gaze upon its ever-changing colours, and to marvel at the wealth of beauty and variation of spectacle that lay in its mighty bosom, always changing, always fresh, always more wonderful than before. One day after breakfast I began strolling down the narrow "Bright Angel Trail" that leads from the summit to the river. Between two and three feet wide in most places, it is wonderfully built and kept in excellent repair for the mule-back parties of tourists that daily descend its seven tortuous miles in the morning and ascend them again in the evening. In places it is like a spiral pathway down an almost perpendicular wall. One looks over and sees it doubling and folding and twisting on itself like a thin white line until it is lost behind some prominence thousands of feet below.

I did not mean to walk down. Walking is not my forte; I only set out to take a few photographs. I have the best of reasons for believing that people never walk down the Canyon. Instead they bulge upon diminutive mules in strings of twenty or thirty or more and make the descent slowly, nervously, solemnly, and more or less in comfort. True, there are places where 
the trail is so precipitous that they have to dismount for safety's sake, but to walk the whole way would be absurd.

Perhaps that was the reason I found myself tramping down the long, steep trail. The more photographs I took, the further down I went to take another. One view followed another with endless change. At every turn there was some new sensation, some fresh vista that just cried out for remembrance. In this way I gradually found myself descending into the depths of the Canyon. Truly it is the most wonderful walk I have ever had.

It was as though the traveller were entering a new world of a new climate, new scenery, and new sensations. Up on the plateau at the top the altitude was 8,000 feet above sea level, and the heat there had been intense. But as I descended thousand after thousand of feet into the bowels of the earth, the air became more dense and the heat more intense until at the bottom, over 6,000 feet below, the climate was almost tropical. Further, the great "temples"-the fragments of the plateau where the erosion had left isolated mountains remaining within the gorge-took on a far different aspect when viewed from below. From above one saw them as one would see hills and valleys from an aeroplane-with hardly any relief. But from below they loomed up sharp against the sky, each one a mighty mountain in itself. What seemed from the brink to be a mere blotch of green mould on the bare rocks below proved on closer acquaintance to be a luxurious coppice, dense with trees and shrubs and tall, thick grass. Minute specks of black scattered broadcast on the slope turned out to be trees that eked out a scanty but sufficient livelihood on the crevices and the crags. A brown, inconspicuous carpet 
from above developed into a huge tropical plateau several miles across. So clear is the atmosphere and so great are the distances that magnitudes are ridiculed and illusions raised to the point of absurdity.

It was well after midday when I reached the bottom and watched the roaring, rushing Colorado, like a great yellow flood, lashing its angry way between the steep walls of the granite gorge. Above, it had been invisible, unknown, and whisperless.

The walk back developed into a tiring, eternal struggle up an interminable staircase that had no stairs. Sometimes I half decided to rest until next day. At intervals I grasped my knees in my hands and helped to lift the heavy, tired feet one above the other. I abused myself heartily for not having furnished myself with reserve refreshments before starting, and then remembered that I had only set out to take a few pictures; I had quenched my thirst at a little creek six hours before, but felt that a meal of some kind would be acceptable.

I arrived at the top about 5.30. The mule-party had overtaken me a quarter of an hour before. They had only stopped half an hour at the bottom for lunch.

"Waal, I've done some walkin' in my time, boss, but I guess you've gotten the best pair o' legs that ever MY optics did see," was the remark of one heavily-spectacled American who beamed from his mule upon me as he passed.

"Aye, that's so," echoed others in the long file with undisguised approbation.

So the reader will observe that $I$ am already becoming Americanized, even in true modesty!

My stay at the Canyon was longer than I had anticipated. Considerable rain had fallen on the second day, 


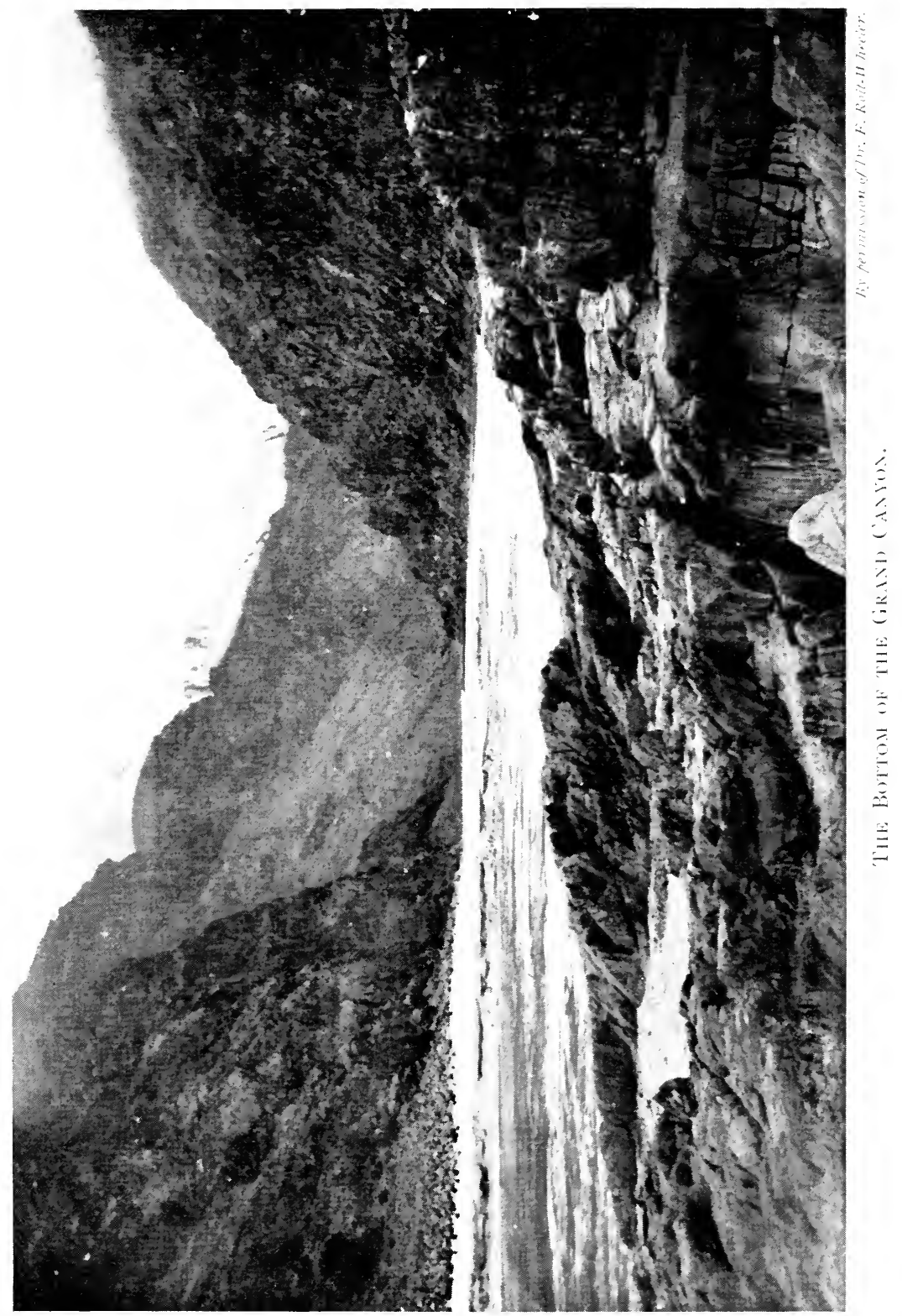



and a report came through that the road in places had been washed clean away. Just what that meant I did not know, but I did not fear it in the slightest. My experience of the roads in Arizona was that they were much better away than present. But I had no taste for mud, so I waited for the sun to do its work before starting back again.

I left the Grand Canyon with regret. Everything was so wonderful and I just seemed to have begun to make friends with it. At first it all seemed so great, so awful, so grotesque as to give one the impression of anything but friendliness. I had begun to overcome that feeling, as everyone does in time. The truth is that it takes a long acquaintanceship with the giant wonders of the world to form anything approaching a true idea of them.

Mud there was in plenty on the way back. In the forest going was bad and slow, for the sun had not had its due quota of time to play upon the damp earth. But in the open there was a marked improvement. The only evidence of the heavy rains was an occasional pool of water between the tracks of the road that had not yet been completely dried up, and this remained as a pool of muddy water within a ring of soft, dark-brown mud.

I was glad that progress was not so bad as I had expected. I was tired of making slow progress, low averages, and big delays, so whenever I had the chance I gave Lizzie her reins and with many bursts of speed where the condition of the road permitted, and occasional hold-ups where it did not, we made pretty good progress for a couple of hours.

Until ... 
We were about half-way between the Canyon and Flagstaff. The country was bare and rocky-almost on the fringe of the "Painted Desert." I was riding on the narrow but level track between the two large ruts that formed the road. I was furthermore enjoying a little burst of speed, my eyes glued on the little strip below me, for if I but once missed it and allowed Lizzie to slip into either of those deep, treacherous ruts that bordered it, there would be a nasty smash.

I must have been too careful, for I had not noticed a fairly large and deep mud-pool dead in the centre of the track and only a few yards ahead of me. There were just about three or four inches between either side of it and those terrible ruts. If I banged into it, it would mean a nasty jar to the machine and possible damage. I judged I could steer round all right without fouling the rut.

The front wheel went through splendidly. The back one, approaching at an angle as I swerved, did not. It just skimmed the greasy edge of the pool and commenced momentarily to side-slip down into the hollow. That was the beginning of the end. I was going fast, and the equilibrium of the machine had been suddenly upset. The nightmare known as a "speed-wobble" ensued.

I did my utmost to check it, but it got worse and worse. From one side to the other the machine swayed, like a great pendulum, swinging faster and faster and each time through a greater distance. For some time I managed to keep the swerves within the limits of the track without fouling the ruts and the rocks at the side, but it was no use; I saw a fearful crash coming.

The wobble developed at an alarming speed; no doubt the heavy baggage on the carrier helped. At the end 


\section{THE GRAND CANYON}

of each oscillation the machine was at a still greater, a still more ridiculous angle to the ground. The front wheel caught something. It had to come sooner or later. With a wild lurch we crashed down on the loose rocks and boulders that bordered the trail. Our momentum was soon absorbed owing to the rough nature of the rocks and boulders aforesaid.

"Here endeth the trip to the coast. Farewell, Lizzie ; it might have happened sooner, you know, old girl." That's what I was saying to myself as I struggled from underneath her remains! 


\section{CHAPTER XIX}

\section{THE MOHAVE DESERT}

I have often thought there must be a guardian angel watching over mad motor-cyclists. Certainly in my case some theory of that sort is necessary to account for the almost entire immunity from personal damage that I have always experienced when fate has led me into crashes of all kinds. At one time and another I have performed wonderful acrobatic feats after a bad skid or a sudden encounter in the dark with a stray horse or a flock of sheep. By all the laws of nature and common sense, I should long since have ceased to labour on this earthly plane. Instead of that, I continue to flourish like the green bay tree, the terror of the country I inhabit, and the bane of the Company that has the misfortune to insure my machines!

Thus it happened that when I extricated myself from the debris, I found myself still sound in wind and limb. Apart from one finger having been crushed between the handle and the final boulder, and the absence of one or two square inches of good epidermis here and there, I had nothing whatever to complain of.

Lizzie, however, wore a forlorn look. Her left handlebar was badly bent and most of the controls and projections on her starboard side were either bent backwards or swept clean away. The stand, a heavy steel structure strong enough to make a suspension bridge, had broken 
away altogether, and had not the footboard been of the collapsing type, it would undoubtedly have shared the same fate.

An hour of doctoring, with frequent applications of wire and insulation tape, and Lizzie was going again. I was relieved in the extreme to find that after all there was a chance of continuing to the coast under her own power. My forefinger pained a trifle, and I could not bear to bend it. I believe always in leaving Nature to carry out her own repairs-it saves a lot of time and bother and generally gets the job finished much quicker in the end, so I spent no time in doctoring it.

We got back to Flagstaff all right that evening and, accepting the hospitality of one of the astronomers at Mars Hill, I spent the night at his bungalow up amongst the pine trees. It was nearly a month before I regained the use of my finger and over three months before the sense of feeling came back to it. Evidently it had been broken at or near the joint.

Two days afterwards I made an unwilling exit from Flagstaff. I was so enamoured with the spirit of the West and the cordiality of its people, as well as the scenery and the climate, that it seemed a shame to move away. But how could I do otherwise when in three days' good running I should be enjoying the reality of the deep blue Pacific washing up against the fringe of some golden Californian valley?

From Flagstaff to Williams, a thirty-mile jaunt, the road traversed the edges of the Coconino Forest. In places it was almost impassable. Stretches of rockhard mud, that had been cut up into fantastic shapes, hindered progress for hundreds of yards at a stretch. I had often to resort to the old expedient of chipping 
the edges of the ruts away in advance to enable Lizzie's cradle frame to get through. Then for miles there were stretches of incredible roughness where often I left the road and scrambled over the rough prairie at the side, leaping over gullies, mounds, cracks, and rocks in preference to the treacherous trail. But the wild scenery compensated for everything. It was exquisite.

Town after town slowly but surely went by, and as they did so, the country grew wilder and the climate hotter. The trail wound through great gorges with towering cliffs that obscured most of the sky. Mad rivers would come rushing down from mountain sides and seldom were there bridges with which to cross them. Vegetation became less plentiful and here and there were stretches of barren prairie land with great boulders and masses of rock spread indiscriminately about them.

Past Ashforks, some sixty miles from Flagstaff, I came upon a Ford car by a wide, rough-bedded, unbridged river. The owner, dressed in blue combination overalls (the standard garment of the West) was playing round it with a " monkey-wrench."

"Want anything, brother ?" I asked.

"No thanks, nothing wrong," he replied, eyeing Lizzie and me curiously up and down. "Gee! What the ..." (his eye caught the number plate)_"Well, I'll be goldarned !"

"How's the road ahead ?" I asked, ignoring his evident amazement at one so young having come so far !

"Pretty tough in places. You've got a fairly good run for a hundred miles, but you've got to keep your eyes skinned for washouts. There's a big one about ten miles further on, just before you come to Pineveta. You can't miss it. It's just beyond a big cliff on the left side 
where it says ' Repent your Sins, the End is at Hand.' And by G-, you'd better repent 'em quick in case anything does happen!"

Washouts there were, good and plentiful. Great gullies had been cut across the roads by the rains. Many were not visible much before they were felt. On the whole it was exciting running.

Pineveta was a most "movie-looking" town. I could easily have imagined myself a Gaumont operator on several occasions. Every building, whether a house, the village church or the town hall, was of wood and of the simplest construction possible. Everything seemed loose, ramshackle and toppling. It was a good home for the tough guys of the West, where towns spring up in a night, prosper awhile and then fade into insignificance.

After Seligman, another twenty miles further on, the trail showed signs of nervous prostration. It led into a great canyon whose grey walls towered high on either side. Then it seemed to say to the traveller, "See here, Boss, you can go on if you like, I'm staying right here; had enough of this." It had already dwindled down to a couple of ruts in the sandy bed of the canyon and now it was besieged on all sides with dense growths of grey scrub, like sage-brush. Even the ruts were barely visible and now appeared only in white patchy blotches through the scrub that grew a foot or a couple of feet high in dense, clustered tufts. It seemed as though something would have to be done about it soon.

Finally we came to a wooden fence, rudely but effectively constructed and barring the way entirely. Behind the fence was a railway track. Evidently it was necessary to cross the track somewhere but not the slightest opportunity did there appear of doing so. I explored awhile. 
On the left, where the trail had ended, the fence showed signs of having been pulled down and ruts in the ground bore witness to traffic having gone that way at some time or another more or less remote. But stay, what is this ? A large post had been torn down from the fence and laid right across the track of the apparent detour. In the middle of it, and fastened on by a piece of wire, was a scrap of paper bearing the following anonymous inscription in scrawled handwriting-"DoANT Go THIS RODE CANT GET THRU."

Now wasn't this kind of some one? I began to wonder if I would have gone to the same trouble if I had struggled through a fence on an old Ford car (I was sure from the writing that it was a Ford) and after proceeding half a mile or so over interminable boulders and gullies had found it necessary to come back again. I came to the conclusion that $I$ would, at any rate, if $I$ was in the West, and thus consoled, I proceeded to search for another outlet.

Yes, here were a pair of ruts leading off backwards at a tangent. Where they went was not possible to see, for they were overgrown with scrub. I started Lizzie once again, put her front wheel into the deeper of the ruts and set off whither it should take me. It was faithful and true. Brushing the bushes sideways with the machine as we passed, we arrived in half a mile at a gate where a good wide road appeared. It was the entrance to the "city" of Nelson, consisting of a few shacks, a ranch-house and a railway station. After opening a few more gates we crossed the rails at a level crossing and were going once again swiftly westwards.

"Dinner in Peach Springs," I told myself. Peach Springs on my AAA Map was a fair-sized town fifteen 
miles ahead. Evening was drawing on and there would not be much light left for travelling, but where dinner was concerned it was another matter. Proceed we must, until fodder hove in sight.

Slowly the canyon was left behind. The country opened out and became flatter. Vast rolling plains appeared, with cedar woods creeping down their slopes. The air was sultry, hardly a breeze stirred in the trees; wild pigeons in hundreds flew hither and thither; occasionally a young antelope or a great jack rabbit leaped across the plains. I hardly gave them a thought. My mind dwelt upon an imaginary tin of pine-apple chunks somewhere in the distance!

Peach Springs showed no trace of materializing when required. There was no sign of it anywhere where it should have been. I stopped at a wooden shack near the roadside. There was a Bowser pump outside the door.

An old man with a goat's beard appeared at the door.

"A couple of gallons of gas, please," I shouted, and while he pumped it in I surveyed the surroundings; there was another little shack not far away and two dirty-looking Mexican women were sitting down outside. Here and there, round about, lay rubbish, pieces of timber, tin cans and other débris.

"Guess you get mighty lonesome here, dad ?"

"Aw, dunno," he replied. "Bin here nigh on forty years. Guess I got purty well accustomed to it now."

"Forty years! I should say so! . . Thanks. Say, how far's Peach Springs from here?"

"Peach Springs? This is Peach Springs. You're in it right here," and he pointed to his shack.

"This Peach Springs? I thought it was a big town with umpteen thousand people in it." 
"And so it was, till they moved it."

"Moved it?" I stood aghast at the thought of such a horrible thing.

"Aye, I mind the time when there was over 40,000 people in Peach Springs. They'd all come in a heluva sweat lookin' for gold, and what's more, they found it. Then the gold begun to give out until in the end there warn't none at all, an' when the gold went the people went with it. I'm the only one as didn't go and I guess I'm not much concerned about it neither. Provisions and gas and oil are better'n grubbin' after gold all yer life."

"Provisions ?" I queried. "Got any pineapple chunks?"

"Sure thing. Got everything."

Overcome with emotion, I filled my pockets with tinned fruit and biscuits.

That night my camp fire burned in a glorious spot sheltered by high cliffs. Fuel was scarce, there were just a few dried-up bushes to burn, but it was splendid, camping there with the beautiful clear sky above, the stars shining as I had never known them shine before.

On again we went at dawn. This time it was to leave behind the cedar forests and the towering canyons. We were getting near the fringe of the great arid desert that stretches for nearly $\mathbf{3 0 0}$ miles to the heart of California. Gradually the ground became flat, almost as flat as the proverbial pancake. On it grew no vegetation at all, save the scanty sage-brush that can flourish where all other things die. Miles away, but clear enough to be only a few hundred yards, rose ranges of saw-toothed, evil-looking mountains, as barren as barrenness could be. Ahead lies the trail stretching beyond the traveller's vision 
to the horizon. On the left runs a fence. Beyond the fence is the Santa Fé Railway. The telegraph poles and the distant mountains are the only objects that break the interminable flatness. The sky is cloudless and the heat of the sun intense. At every five or ten miles a stop is made to drink water from the bag on the handlebar. One has a glorious thirst in these parts.

Mile after mile goes by, and hour after hour. The sun grows higher in the heavens, its rays pour down upon my back with unrelenting fury. When shall we get to anywhere? The inner man grows weary of fasting in this infernal heat. A massive rock, lying all alone in the vast plain on the right, asks: "Why will ye not repent?" Oh, the irony of it! The man who painted that rock was a fanatic, but he knew what he was about.

Kingman at last! Kingman meant breakfast. Breakfast meant water melons and coffee and pies and other good-nay, beautiful-things. Kingman meant drinks and ices and sundries to one's heart's content, and one's pocket's contents.

On again I pursue my way, feeling like a new man. Next stop Yucca, thirty miles. Gee! the sun is hot. Nearly eleven. My stars, what will it be like at one ? Everything is sand now-underneath, around, everywhere. The wheels tear it up in clouds as they skim through. Sometimes they slip sideways in it and flounder about, trying to grip on to something firm. Sometimes we slither over altogether but the sand is soft and spills do not disturb one much. But the sun-I wish it would stop working a bit!

Vegetation appears once again, but of a very strange kind. It is a vegetation that is different from any we know in Europe. It is at the same time grotesque, mysteri- 
ous, ridiculous, wonderful and luxurious. It is desert vegetation. You have always thought of deserts as devoid of every sign of vegetation? It is not so in the great deserts of America. Life abounds but, as if in recompense for the privilege of living, it has to take strange forms. Yet, if they are strange, it is only in comparison with the vegetation to which in temperate climes we are accustomed. The unnumbered varieties of cactus plants and trees are in reality beautiful and strange beyond description. They are always green, always fresh and always beautiful. It is a kind of "Futurist" beauty that adorns them. The cactus trees, for instance, have their leafless branches projecting almost at right angles to the trunk, and they in turn branch out in a similar manner, presenting a grotesque appearance. The tall and beautiful Ocatilla-one can almost refer to it as a desert "shrub"-springs directly from the ground like several long waving feelers bunched together below and spread apart above. The prickly-pear, with its needle-covered fleshy leaves, each one joined on to another without stem or stalk, presents a most weird aspect. Even the modest and unassuming sage-brush, the poor downtrodden "John Citizen" of every desert, seems to have been arranged on the barren plain in regular rectangles and rows, spaced at mathematical distances apart.

The secret is that each one has to think of only one thing-water. Each cactus plant or tree is provided in itself with the means of storing a reserve of water. Moisture is the one great thing that dominates them all. That being so, the constitution of desert vegetation has to be altogether different from that of humid climates just as our constitutions would have to be entirely different if we lived on Mars, where there is hardly any water at all. 
This was truly a world of wild fancy. It would be ridiculous-I thought-to try to explain a scene like this to people who had never seen anything but ordinary trees and plants and flowers. They would laugh in scorn when I tried to describe to them that strange conglomeration of fanciful shapes, those mad-looking cactus trees with every joint dislocated, those weird Ocatilla waving their long slender arms twenty and thirty feet above the ground. And look at that great organpipe cactus over there, nothing but a huge light-green fleshy trunk, with two or three other trunks all perfectly straight and perfectly vertical on top of it! How could one possibly describe things like that?

"With a Watch-Pocket 'Carbine,' of course. What else?" I mused and stopped to take out my camera from the toolbox. It was not so easily done as said. The toolbox lid seemed red-hot to my fingers. I could not bear my hand on the top of the tank even.

Oh, water, water: how beautiful thou art! Even when imbibed under hand-pressure from a smelly canvas water-bag!

Could it EVER get any hotter than this? The only way was to keep going, the faster the better. Then the heat, with frequent drinks, was just tolerable. When I stopped, it was like being plunged suddenly into a great furnace. Never mind; there would be ice-creams at Yucca. On again, as fast as we can, leaping over gullies, ploughing through the loose white sand. Lower and lower we get as we travel. The gradient is not noticeable, for there are ups and downs all the way, and ridges of hills here and there. All the same, we are making a steady descent. In a couple of dozen miles we shall cross the River Colorado. That morning we were over 
a mile high above it. Now we are at its level. That explains the increasing heat the further we go, and further on for hundreds of miles the road lies but a few feet above the level of the sea; in places it is actually below it.

In the distance appear trees-poplars, eucalypt us and cedars. They denote the small ramshackle town of Yucca, like an island in the plain. The trail widens into a road. Living beings are seen, horses, carts and motor cars. It is the civilized world once again. What Yucca does for a living I am at a loss to know. It cannot certainly be a ranching town. Probably there is a little gold in the vicinity and it is a small trading centre. Probably it is more important as a thirst-quenching centre!

A short stop and on we went again into the desert, leaving behind us the little oasis, and plunging ahead into a still hotter region. The strange cactus trees and desert plants gathered round once more. Rougher and rougher the road became. The sand gave place to sharp loose grit interspersed with rocks and jutting boulders. As it did so, gradually the luxurious vegetation of the desert grew thinner and the dull miserable sage-brush took its place. The trail divided up into two deep and solitary ruts and in between them lay loose shale and grit that absolutely defied progress. The wheels would sink in freely and churn the road up aimlessly. It was necessary then to ride in one of the ruts. Where they were broad this was not difficult, but when they narrowed and deepened a spill was almost bound to occur if one wobbled but a fraction of an inch from the dead centre of the rut. Negotiating a road of this nature was something new in the sport of motor-cycling, but it was exasperating. I was to find later that riding continuously in a rut was like riding on a greasy road, in that the more 
carefully one went and the more timid one grew, the more dangerous did the riding become. Time and time again I was thrown off by fouling the side of the rut and plunged headlong over the handlebars into the road. The slower I went the more often was I thrown. If I travelled about ten or twelve miles an hour I could maintain my balance by using my feet where necessary. Riding at that speed, however, was out of the question. It was better to go faster and risk the frequent spills than to be roasted alive. So I went faster. The faster I went the easier was it to maintain balance naturally, because the steering became more sensitive and only a very small movement of the handlebars within the limits of the rut would suffice to correct any deviation from perfect balance. I found that at between thirty-five and forty miles an hour it was moderately easy to follow the rut through the swerves in its course. But even then, occasionally there would be a nasty spill, a few bent levers and some scratches. (I learned a week or so later from "Cannonball Baker," the famous American racer, that he travels in these same ruts at between fifty and sixty!)

Here and there the trail would cross a "wash" or a dried-up lake bed and then the sand régime would reappear. And ever did death speak from all around -desolation in bewildering intensity almost cried aloud from the fire-swept waste that lay all about me. Often I passed the remains of derelict cars left at the side of the road; sometimes it was a mudguard or a spring, a tyre or a broken wheel; sometimes it was a complete chassis, stripped of everything that could be taken away. For what could be done in a region like this if the breakdown were too large? Nothing but to push the car off the road and leave it to its fate. Almost without 
exception the remains were of Ford cars. That shows the wisdom of travelling in a machine that bears no great loss if it is damaged or forsaken !

Occasionally I passed a gigantic heap of small tins all rusty and forlorn. I was puzzled at first. How did they get there? And why had they been heaped up if they were the discarded food-tins of passing travellers? But no. They are the sole remains of a "mushroom" town of the West. In them one can picture the sudden growth and the almost equally sudden decay of a settlement that thrived while there was gold to be found in the vicinity.

Here and there, too, were little heaps of bones, bleached white as snow-the remains of a horse or a cow that had strayed. To lose oneself, be it man or animal, is sure death in the Mohave Desert.

It is just mid-day. The sun is vertically above. It beats down on my shoulders and dries up the skin of my hands. My hair, over which I had never worn a hat since I left New York, is bleached to a light yellow colour and stands erect, stiff and brittle. The alkali sand and dust have absorbed all the moisture from my fingers and gradually cracks and cuts are developing in my finger tips and at the joints. I find it easier to grasp the handlebars with the palms of my hands alone. My clothes are saturated with dust and my trench boots are cut and scratched, with the seams broken away; the right sole has pulled away and threatens to come off altogether unless carefully used. I feel that the sooner I get out of the Mohave Desert the better it will be for me.

But the heat! It seems to know no shame, no pity. It is terrific. Every five miles I stop and drink from the water bag. There is just enough to carry me to the 
next stop. For the first time I begin to long for shelter from the burning rays. There is none around anywhere -not as far as the horizon. I must push on quickly. . . . The rut suddenly breaks and swerves away. ... Crash ! . . U Up again, lose no time. On once more; what matter if the footbrake doesn't work? A motorcycle is made to go, not to stop!

In front, to the left, rise pinnacles of purple granite. They stick up sharply into the sky like the teeth of a great monster grinning over its prey. They are the "Ncedles," and they fringe the Colorado River. What a glorious sight it will be to see a river again, with water flowing in it.

Now on the horizon appears a blotch of green. Its beauty in that yellow wilderness is beyond description. It is the green of the stately poplar trees that surround the railway station of Topock. That is where the road and the railway and the river all meet, and where we leave Arizona and enter the State of California. Thank Heaven it is not far away. The pinnacles rise higher and higher, the little oasis grows bigger and bigger, and the trees greener and taller.

At last! Lizzie's rattle is silent. We come to rest under a great shelter thatched with straw that has been erected by the roadside opposite the restaurant-the only building in the town beside the railway station. A few yards further on was a massive steel bridge 400 yards long that spanned the Colorado. Beyond lay California, but I was satisfied with Arizona and the strawthatched shelter for an hour or two.

* $\quad * \quad * \quad * \quad * \quad *$

At two we crossed the great bridge. What good fortune 
would California bring, I wondered. It brought even worse roads than I had seen in Arizona. There still remained over 200 miles of desert to be crossed. The trail was very rough, like a mountain track at the start, full of ups and downs and swerves and washes. Twelve miles further on $I$ arrived at the town of Needles, so tired and hot that I decided to abandon travel until the evening. Then $I$ would ride out into the desert and make my bed under the steel-blue sky. I was too enamoured of the wonderful sunsets and the glorious sunrises of the open plain to allow them to pass unseen in a musty, stuffy hotel bedroom.

Needles, I was surprised to find, was very much bigger than I had expected. It is now a good-sized town and its main street a bustle of activity. After disposing of a steak at a Chinese restaurant, I bought a book and retired to the square. There I took off my tunic, rolled up my shirt sleeves and lay on the grass beneath the tall, thick palm trees and whiled away the hot afternoon hours.

At evening as the setting sun was drawing a magic cloak over the tropical sky, I stole out of Needles along the lonesome trail that I had learnt to love. Except for low-lying mountains all around, there was nothing but the everlasting sand and sage-brush. Behind lay the gigantic plain and across it, like a silver snake, crept the great silent river. It was the most impressive scene that I have ever beheld from my bedroom window. My mattress was the sand with a waterproof sheet laid upon it. Never did Monte Cristo with all his wealth sleep in such luxury as that.

He who all his life has associated the dawn with the soft greetings of birds and the mellow noises of awaken. 


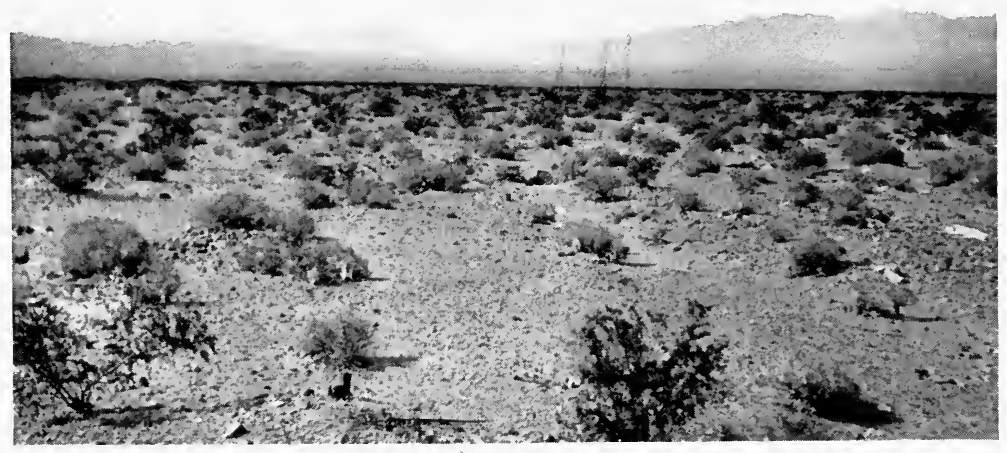

IN The Mohave Desert.

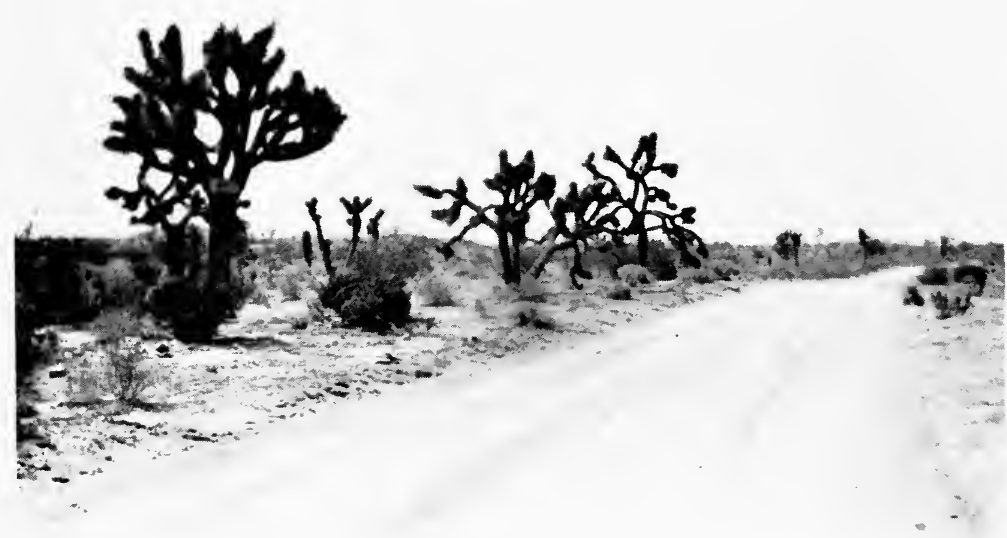

Cactus Trees Near Sax Bernardino, Callfornia. 

ing nature, is struck at once with the vast difference of desert countries. I have read that in unexplored Africa and South America, the dawn is heralded by a mighty tumult of millions of voices, a great chorus of every soul in the great populace that lives in forest and jungle. In the Mohave Desert the majesty of the dawn unfolds itself in deathly silence. The entire absence of sound of any kind is awe-inspiring, almost weird, and the observer can but watch and wonder at it as he sees the whole firmament set ablaze with colours and shades that he never imagined existed, and gradually the silent grandeur of the spectacle is revealed.

It was with just such feelings that from my bed I watched the unfolding of another day from the depths of the great silent plain which lay beyond that thread of silver in the distance.

And then, on again. There was a low range of mountains ahead to be crossed. It was slow work and very tiring. The constant looseness of the surface, the need for everlastingly keeping one's eyes glued to the trail, and the terrible monotony of it all for mile after mile, made me long all the more for a sight of the orange groves and the blue sea beyond that to-morrow I might, if nothing unforeseen happened, enjoy. Thus went fifteen, twenty, thirty miles. The first halt was reached. It was only a railway station, a "hotel," a garage and two or three houses, but it meant breakfast, and a good one at that, for the journey that was ahead. Feeding over, out we went once more to brave the ruts and the rocks and the sand, for miles and miles unending. The morning sun grows slowly into a midday sun.

We have been climbing a little. Low-lying ranges of absolutely bare, purple-brown jagged hills seem to hem 
us in. Soon we shall be across them. Beyond there will be-what? More, perhaps. The road here has been "oiled," that is, the sand has been levelled and then crude mineral oil poured on. This hardens the crust and prevents the road from blowing away, giving to the uninitiated the impression of well-laid macadam. It is a relief after the loose sand, and it looks so strange for a black, broad highway to be going across a desert ! It does not last long, but comes and goes in patches. Where it does appear it is often lumpy and cut into grooves and slices. Nevertheless it is welcome. . . . The road turns when it reaches the crest, continues for a few yards, and then ....

A marvellous sight has suddenly appeared, viewed from the meagre height at which we stand. A great plain lies beneath and before us, greater and flatter and more desolate than my imagination could ever have conceived. All around it are mighty saw-toothed ranges of mountains pressing close upon the horizon and fading away into nothingness. In it is nothing, not a prominence of any kind, save the omnipresent sage-brush that seems to stretch in streaky uniformity like a great purplebrown veil above the cream-white sand. It is impossible to go on-to do anything but stop and wonder that over so great an area nature can be so desolate. It is wonderful, mystifying in its intensity.

Did I say there was no prominence? What are those two minute specks away over there in the heart of the plain? They must be a tremendous distance away, but in their very minuteness they are conspicuous. It is obvious that they are not there by the design of Nature. . . As I look, a tiny white speck appears further still to the left, as though it emerged from behind the range 
of mountains that I have just crossed. Look! There is a short black tail behind it. It is a train!

Slowly, almost imperceptibly, it moves across the great wilderness. The black specks then are stations, small man-made oases where water has been brought to the surface. Yes, it is true. Ten minutes elapse, and the little white speck merges into the little black speck. Thus are sizes and speeds dwarfed into insignificance when Nature has the mood to show her magnitude!

On again we go, spinning smoothly awhile over the smooth, oiled road. It stops in a mile or two and leaves nothing but the old heart-rending, twisting, wayward ruts and sand to guide us. Hours go by. They are hours of wild effort, maddening heat, and interminable boredom. Generally, every fifteen or twenty miles, there was a railway station and a restaurant where one could stop for drinks, ices, and petrol.

Four o'clock saw me in Ludlow, a small town, larger than the other stops. I was dead tired. Come what may, I was not going to work myself to death. I had done 200 miles since daybreak. That was enough for anyone in a country like this.

At eight o'clock I set out with Lizzie in the deepening twilight to find a resting-place for the night. The road was oiled, but in most places the sand of the desert had blown over it, covering it for several inches in depth, and sometimes obliterating it from view for many hundred yards.

"I will sleep at the foot of yonder hill," quoth I, and saw visions of concrete roads and orange groves beyond the horizon. 


\section{CHAPTER XX}

\section{REACH THE PACIFIC COAST}

I saw something else on the horizon too. It started as a little black speck on the road, seeming to swerve now and then from one side to another. It emitted a strange noise that at first was scarcely to be heard, but increased until it reverberated indefinitely from the bare angular mountain ranges.

It was a motor-cycle!

An inexpressible feeling of sympathy and comradeship surged through me, as I realized that here was another fool starting to do what one fool had already almost done. I wondered vaguely whether he knew what he was doing.

We both stopped, dismounted, and looked at each other for a few moments before either spoke. The sight of another motor-cycle seemed to take both of us by surprise. The stranger, a young man of twenty-four or so, had an old twin-cylinder Excelsior that looked very much as if it had seen better days. I led off the conversation.

"Where do you reckon you're going on that?"

"New York."

"Ever done it before?"

"Nope."

"Insured ?"

"Nope." 
"Pleasure or business?"

"Both." Here he fumbled around a huge bruise on his forehead. "Leastways, that was the idea. I'm writing it up for the Adventure Magazine when I'm through "and he added guardedly, "That is, if I don't kill meself with a few more headers like this."

"How'd you get that?"

"Oh, Boy, I came such a crash on a bit of oiled roadway back there by that salt-lake bed. Don't remember anything of it except being chucked clean over the grips about fifty. My Gad, it was some crash ! I came round about half an hour after. Say, Boy, you look out for them ruts; ride plumb in the middle of the road, and you may miss 'em, 'cause they're filled in and blown over with sand. Jest the right width of your wheel, they are."

"Sure, I've made their acquaintance already; kind of keep a man fit, don't they? But, say, you've got many more like that coming between here and New York. Take my tip, old man. If you've got anyone depending on you for a living and you don't want to knock the ' $\mathbf{X}$ ' and yourself to little pieces, you had better go back home right now and tootle up and down the Californian coast for a holiday. And if you still want to get to New York-well, all I can say is, there's a dem fine train service, and you'll find a depot right there in Ludlow."

"Don't you worry, Boy ; I've done a heap of motorcycling in my days and I guess I don't get scared at a header or two, and s'long as I can fix anything that happens along, I guess I'll git to Lil Ole Noo York before a couple of weeks is gone."

"Young man," said I in a fatherly tone, "you don't 
know what you're saying. You're talking blasphemysheer heresy. Your crash has turned your wits a little."

"Thanks, but I've made up my mind to go by road, and go by road I will."

"That's the spirit, but just a few more words of advice. Sell it and buy a Ford. Then you'll be able to take some one with you."

"I'm taking some one already, Boy. He's back at Ludlow. Shipped him on from Barstow, the road was so dog-gone bad and he got scared at the desert."

"What! You're taking him on the carrier?" I cried aghast.

"Sure enough. What's against it?"

I was speechless. His youth and innocence held me spellbound for a moment. Then I burst forth:

"Man, you're mad! Absolutely Mad! Here, c'mon, Lizzie, before it gets too dark and before this lunatic gets unsafe." I kicked her into a roar. "Cheerio, old man! Give my love to the Angels to-morrow!"

Then his open exhaust burst into a clatter and I saw him no more. I often thought about him, though, and wondered how, when, and where he ended up.

Next morning I shook the desert sand from my blanket for the last time. By hook or by crook I should be sailing through the streets of Los Angeles before nightfall. I judged I looked pretty fierce on the whole. I had no looking-glass, having left my suit-case to be shipped on back at Santa Fé, but I had the best part of a week's growth on my chin and I had not known the joy of a wash for four days. My hair, my boots, my clothes, my everything, were saturated with sand and dust. My tunic, which in its earlier days had been a green tweed, was now white at the back, bleached almost colourless 
with the sun and then soaked with alkali dust. In the front and below the sleeves it maintained something approaching its original colour. My boots ? Well, they had not been off for four days, and the right sole, which had been threatening revolution, had so many times nearly tripped me up by doubling underfoot, that I had removed it near the instep with my pen-knife!

And Lizzie was in no better condition. Externally she was a mass of string, wire, insulation-tape, mud, oil, and sand. Internally she was a bundle of rattles and strange noises. Everything was loose and worn; the sand had invaded her at every point and had multiplied wear a thousandfold. Latterly the tappet rods had had to be cleaned and adjusted over a sixteenth of an inch every day until there was no more adjustment possible. The valve rockers were worn half-way through, some more than that. One had worn right through until it had broken in the middle. I began to be afraid that the engine would not hold out even for the 200 odd miles to come. By handling her carefully and giving her ample oil, I hoped to "deliver the goods" and get across the remaining half of the great desert tract that borders on the Sierra Madre Range running parallel with the coast from north to south. Once across that range, everything, I told myself, would change abruptly, the roads, the scenery, and the climate.

Mile after mile of rock and sand went by with the sweating hours. Often little patches of oiled road appeared, stayed awhile, and then miraculously disappeared below the white, loose surface. Nearly always there were two ruts, beautifully sharp and well cut, sunk three or four inches below the rest of the surface, caused by the fierce rays of the midday sun converting the oiled 
surface into a plastic condition easily moulded by passing cars which, once given the lead, follow blindly in the others' "footsteps." Many a bad swerve and an occasional spill did I have when my front wheel found such as this. But the major portion of the road was just the bare, loose sand and gravel of the desert.

I had by now become so used to my own company that the sense of loneliness almost disappeared, and I felt as perfectly at ease here as anywhere else. I felt that the great wastes had a charm, nay, even a lure, that eclipsed all past sensations and gave a mental satisfaction that no other phase of Nature could ever reveal. I cannot describe the ineffable something which made me love the great solitude and the mighty spaces, but it is there nevertheless, and, like the greatest of passions, it gives extremes. After one has lived but a few days in the desert, either he loves it passionately or he loathes it. There is nothing in between.

On the right there lies the great "Death Valley" that stretches a hundred miles to the north between the Armagosa and the Paramint Mountains. Its name is suggestive of the many people who have miserably perished of thirst in its clutches. It is the remains of a long-since dried-up inland lake and parts of it are $\mathbf{1 5 0}$ feet below the level of the sea. There is nothing in it save bare rock and shifting alkali sand, with here and there a cactus or a little sage. The heat is tremendous and the thermometer sometimes rises to $140^{\circ}$. In all, not a pleasant place either to live in or to die. But there are those who in the search for gold live here for months at a stretch.

Confound it! There goes No. 1 cylinder again. Why doesn't she fire? Am I to start overhauling the engine 
in this terrible place? I stop to change a plug. ... Nothing doing. . . . Try another. . . . Still no result. For ten minutes I tinker with red-hot tools. Gee! the blessed machine will be melting soon if we don't move quick. In disgust I go on again with only three cylinders working. Past memories crowd into my mind, but the eternal battle with the loose sand suffices to keep them out.

It was too bad, to start playing pranks like this within a few hours of the coast. The sand of the road absorbed most of the power I now had left and often I had to change down to bottom gear to get along at all. It was wonderful what a difference just that one cylinder made, and it was most annoying that it should happen just here, where the earth was nothing more than a confused mass of rocks and sand, and the sun stood vertically above in the sky. "Thank Heaven, I've some water left, if anything happens," thought I.

"What in the world is that thing ?" I asked myself. Closer acquaintance proved it to be a motor lorry, dressed up as a caravan and minus a back axle-a most remarkable sight in most remarkable surroundings. From the numerous loop-tracks that swerved around it, it had evidently stood there many days. Its owner was lying underneath on his back.

"Pretty place to change a back axle, old man," I remarked intelligently.

"Yep. Not the kind o' thing a feller does for the fun of it, either," he retorted, scrambling out from his restingplace in the sand.

"Well, is there anything I can do for you, anyway? I don't quite like to see a chap stranded in a blanketyblank country like this on blankety-blank roads like 
these." I forget just the adjectives I used, but I know they were hardly of the drawing-room variety. Imagine my surprise when a feminine voice from inside chirped out :

"Yes, that's just about got 'em sized up! I've never heard such a mighty cute description of 'em."

Five days they had been there. The back axle had broken under the huge strain of dragging the load through the deep, loose sand. A passing car had taken it to San Bernardino to be repaired, and other passing cars had kept them well supplied with water. They expected to have the axle back the next day and then had nothing to fear. As I could do nothing for them, I propped Lizzie up against the side of the lorry and tried once more to persuade No. 1 cylinder to join hands with the rest.

After half an hour of useless toil, I bade farewell to the caravan and its occupants.

"Quite sure I can't do anything ?"

"Plumb sure, thanks. Mebbe we shall be there before you, y'know," - with a wicked twinkle in his eye.

Then followed hours and hours of ceaseless toil. We climbed hills and crossed great lake-beds that glistened white with a dazzling glare. In some of these there was nothing to be seen in the vast stretch of alkali deposit where once, thousands of years ago, rested the briny waters of lakes and inland seas-nothing, not even a plucky bush of sage-brush, clinging valiantly to its lifehold.

We came to Barstow, a growing settlement, a railway centre and with great alkali factories. Here, after nearly 100 miles' running, I had a substantial breakfast-lunchdinner meal and filled my water-bag for the last time. We were nearing the end of the Mohave Desert. 
Here the trail turns sharply to the south to "San Berdoo," the colloquial abbreviation of San Bernardino. At one time the trail had crossed the desert by a different route altogether, in places almost 100 miles from the railway line. So many souls had perished with the heat and lack of water-perchance through some breakdown or through losing their way-that later a new road was " constructed" following closely the track of the railway so that travellers by road need never be in difficulties for long. It is an unwritten law in any of the American deserts that anyone can hold up a train anywhere if he needs water or supplies or other help. It is willingly given, whether it be a freight train or the "California Limited" express from New York to San Francisco!

The San Gabriel Mountains now rose high on the horizon. They had but to be crossed, and then all our troubles would be over.

So I thought.

At Victorville, a growing town at the north base of the range, the desert had almost disappeared. Eucalyptus trees became strangely intermixed with cactus trees, and the aroma of their long, grey-green leaves filled the air with a new sensation. It was the approach of civilization once again.

And then followed the long, winding climb up to the Cajon Pass. In the thick sand and with only three cylinders, it was hard work and slow work. I thought we should never get to the top. Looking back, I beheld a wonderful panorama of desert plain, and a glistening sea of sand; looking forward, I saw just a gap in the great black wall and a rocky pathway winding through it.

Are we NEver going to reach the summit? We must 


\section{ACROSS AMERICA BY MOTOR-CYCLE}

have climbed nearly a mile high already, I argued with myself, when, of a sudden, the twisting, rocky trail ceased to exist. It vanished like magic, and instead there was before us a magnificent, broad highway of smooth, flat concrete that made me yell with delight. It was wonderful. I laughed and sang with childish glee to think that after 4,000 miles of mud and sand and soil and rock and rut and unspeakable goat-track, I was at last on a concrete road once again, with a surface like a billiard table. I swerved madly from side to side to make sure those two haunting ruts had really disappeared, and laughed again when I found I was not thrown off. It was just glorious.

One more turn, and a great valley lay at my feet. It was green with grass and the mountain sides were clothed in pine trees. Pine trees! How beautiful they looked! It was surely a dream, a vision, a trick of the imagination. There was a long, winding gradient down into the valley. I shut the engine off and we coasted down the smooth concrete without even a whisper or a jar of any kind. It was like a sudden entry into heaven-and almost as silent.

There were now seventy miles of concrete leading between avenues of eucalyptus and groves of orange trees into Los Angeles. Further, the road was almost perfectly flat, although bordered by the San Gabriel range, and, with a few right-angle bends here and there, cut straight across from east to west, with hardly a swerve from the straight line.

Truly it was like a new world, this fruit garden of California. For miles unbroken save by little avenues, one passed row upon row of orange trees laid out in perfect symmetry and exactitude in the rich flat soil. A narrow ditch, dug parallel with each row and having 
small branches to each individual tree, communicated with larger ditches along which flowed a constant stream of fresh water led from the mountain sides.

Interspersed would be groves of prunes, peaches, and apples, then a plantation of water-melons and cantaloupes of all shapes and sizes.

And then, as if to snatch away the enjoyment of all these pleasant things, a great clatter arose from the engine. Something had broken at last, and it seemed that the whole was a revolving mass of loose pieces all knocking up against each other. Then, before I had been able to slow down-it all happened in a few seconds-there was a metallic thud, the back wheel locked dead, and the machine dry-skidded itself to rest. Once again Fate had decreed against me, angry that I should have got so far in spite of all her efforts.

Well, well! There was plenty of time to spare now ; no need to hurry. I sat down on the grass at the roadside in the shade of an orange tree, ate two orangesfrom the tool-box-and smoked a pipe. Feeling refreshed in every sense, $I$ then proceeded to take the engine to pieces.

No. 1 piston had broken in fragments and a large piece had jammed between the big end of one of the connecting rods and the crank-case. It was strange that it had not punched a hole through it.

It was far too long a job to take off the sump at the roadside-it would have meant taking the whole engine out of the frame-nearly a day's work-so I removed as many of the pieces of piston as I could get at through the inspection window. The piston-head was floating loose like a flat disc above the small end. This I removed and packed the two halves of the broken gudgeon pin 
apart, so as to guide the small end up and down in the cylinder. It was impossible to remove the connecting rod entirely, even with the cylinder off, without removing the whole engine from the frame and taking off the sump.

In a couple of hours I was going again, but very very gingerly, lest another piece of piston should be caught up and cause another jamb. The noise of the rattle too was terrific, and I could hear the warning of passing cars (of which there were now several) only when they were right behind me. Sometimes it would get suddenly worse and a further disrupture would appear imminent, and then it would go suddenly back again to its normal. Thus we toiled for thirty miles, at an average speed of twelve miles an hour.

At Ontario-the towns were as numerous as they were prosperous-I feared another and final episode. A Ford car that was passing slowed down to offer me assistance, and putting Lizzie in "free engine" I hung on to his hoodstays with my right arm as a tow-rope. This lasted for ten miles, but I could stand it no longer; my arms were stiff and aching with the uneven strain. I thanked my benefactor and let go.

The remaining twenty miles into Los Angeles were endured and accomplished under our own power at about eight miles an hour. The attention I attracted was considerable. Hundreds upon hundreds of cars, buses, and motor-cycles passed, hurrying here and there, their tyres making a continuous low hum on the concrete road. Luxury, wealth, and happiness abounded on every hand. No greater antithesis to the aching void of the desert back behind the mountains could be imagined.

Every house was a picture, a model of cleanliness and homeliness. The art of building bungalows is reduced 
in California to the irreducible. It is amazing to see the variety of design and the characteristic beauty of them all. They made the modern English bungalows of my memory seem like enlarged dog-kennels by comparison.

At five o'clock in the afternoon we rattled into Los Angeles, the New York of the Far West. Lizzie's clatter rose above the noise of the trolley cars that thronged the busy streets. Here at last was the long-sought-for goal-the goal that for nearly three months had urged me westward! And my steed? Poor Lizzie, she cried aloud for a respite from the long, weary journey!

Had I known where the Henderson Agency was I could not have found my way there quicker. It seemed as if Lizzie's instincts had taken her there just as a lost cat, transported hundreds of miles from home, slowly, painfully and perseveringly drags its tired body back again.

A quarter of an hour later I was sailing in a side-car towards the "Clark Hotel." That was where my hotel at Santa Fé had recommended me to go and had forwarded my baggage.

We drew up at the door of a palatial establishmentthe "posh" hotel of Los Angeles. Once again, after many a long day, my knees began to quake. Brushing by the magnificent door-porter, I swung into the luxurious lounge. Afternoon tea was just finishing. I strolled across to the reception desk, trying hard to maintain an air of complete innocence as regards my personal appearance. I endeavoured to assume an attitude of perfect congruity with my surroundings.

To say the least, I was lamentably unsuccessful ! Little groups of people chatting together stopped and gazed 


\section{2}

\section{ACROSS AMERICA BY MOTOR-CYCLE}

at the dishevelled intruder. Imperfectly disguised smirks were evident on all sides. Pages, bell-boys, and porters quickly brought their grinning faces to attention as I glowered upon them in turn. At last I reached the desk.

"You've got some baggage for me, I believe-a couple of grips-sent from the 'Montezuma' at Santa Fé. Shepherd is my name."

Meanwhile the manager appeared on the scene. Resting himself with both hands on the desk as if to steady himself against any possible shock that he might receive from the contemplation of so strange a spectacle, he gazed at me in silence. Then, below his breath, he found words to convey his astonishment :

"My Gad!" he said, and paused deliberately. Then he continued explosively, "I've seen some sunburnt faces in my time, but never, NEvER, NEVER have I seen a man anywhere with a face like yours!"

"It's nice of you to say so," I retorted.

"Heavens, man!" he continued, ignoring the interruption, "your hair's nearly white and your chest is nearly black. Where in hell have you been ?"

" Oh, I didn't stay there long," I replied, " no longer than was necessary to get here from New York."

"New York!" (I was quite expecting him to say "Whar's that?" but evidently its existence was known in well-informed circles in Los Angeles). "Have you walked it or swum it or what?"

"Only motor-cycled it, Old Bean!"

"Well, now, if that's not. . . Here; I'll give you your key. Go and have a good bath RIGHT Now."

I thanked him. A porter had got my bags and stood waiting. His face was the essence of staid immobility when I looked at him. Together we went in the elevator 
to the $n$th floor. Eager to see what I really did look like, my first indulgence was to look at myself in the glass, a thing I had not done for many a day.

It certainly was a shock. I could barely recognize myself. I really was the most remarkable creature I had ever seen. I could not refrain from bursting into uncontrollable laughter. The hitherto straight-faced porter did likewise, and we both felt the better for it.

A hot bath! Wonder of wonders! I tumbled into it and the past was forgotten in the inexpressible ecstasy of the present. 


\section{CHAPTER XXI}

\section{LOS ANGELES TO SAN FRANCISCO}

In full, the real name of Los Angeles is "La Puebla de Nuestra Señora la Reina de los Angeles "_-"The City of our Lady the Queen of the Angels." Founded by

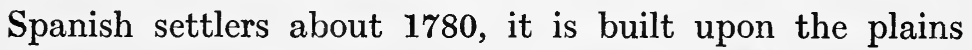
that roll from the foothills of the Sierra Madre down to the sea. It represents the very last word in the civilization of the Far West.

Los Angeles is a city of which to be proud. It is a hustling metropolis, but not too hustling. Its streets are wide and well-laid, its buildings clean, and its residences are just too wonderful for any words of mine. It is moreover the "movie centre" par excellence of the world. "Duggie" and "Mary" and "Charlie" are not merely familiar characters on the screen. They are your neighbours. You see them pass in the streets and go shopping with them in the stores, like ordinary human beings. Undoubtedly the development of Los Angeles in recent years is due largely to this industry. So also is the amazing beauty of its feminine population. Going deeper still, we find that the secret of its success lies in the wonderful climate. There is but one rainy season in Los Angeles during the year, and that is the month of December.

Strange to say, Los Angeles is not on the sea-coast. It is twelve miles to the nearest part of the beach. This 
seemed rather extraordinary to me, particularly as San Francisco, with whom they are so eagerly competing, stands on one of the finest and largest harbours in the world. I remarked so to the Times reporter one day. "But why," I asked, " did they build Los Angeles so far from the sea?" "Oh well, you see," he replied in all seriousness, "they had a mighty good idea about things. They reckoned that by the time Los Angeles had really started growing she'd be right on top of the Pacific, so they gave her a chance and laid the place out twelve miles away." "Oh, was that it ? I see," was my innocent retort.

Be that as it may, there is a network of beautiful, straight, concrete roads leading from the city down to the coast in all directions. Dozens of small residential towns are springing up amid this network of roads-towns that some day will be suburbs of Los Angeles. At least that is the way to think of them. And the roads themselves ? On Saturday afternoons and Sundays they are like great living arteries along which flows an endless stream of motor-cars. The Californians know how to enjoy themselves. There is not one fragment of the art of exterminating boredom that they have not studied. They frivol en masse, and to do it they naturally choose the seabeach as a habitat. Consequently the coast is strung with dozens of seaside resorts of every type and shade of description, and with only a mile or two between them.

A trip to one of these "Los Angeles Beaches" is essential to the education of the true student of Southern Californian civilization. Never at any time have I seen public highways so completely covered with motorcars. The number seen approaches the incredible, in the eyes of the astonished European. Frequently there 
were two almost endless rows of cars with but a few feet between them, moving slowly along like a gigantic procession several miles in length. Occasionally there would be a hold-up, and the whole string of cars, one after the other, would pull up, each car close upon its forerunner. Without exception, all American cars are provided with buffers at front and rear so that the car does not suffer any damage when one touches another even with quite a severe impact. The obstruction is removed, and on the procession goes again. Perhaps some unfortunate is changing a wheel at the roadside. Then there is a big curve in the long, straight line where the more fortunate Fords and Maxwells and Buicks and Overlands, etc., etc., swerve round him. And thus we carry on until the coast is reached.

Naturally the first glimpse I had of the Pacific Ocean gave me feelings of unbounded joy. I even confess to having obeyed the childish instinct to pick up shells and seaweed on the beach. It was a sight to look upon until the majesty of the breakers and the infinite expanse of the deep blue ocean eclipsed one's sense of magnitude altogether and one became lost in a world of vision and fantasy.

I spent over a week in Los Angeles. During that time I was almost overwhelmed with hospitality. The Californians I found easily the most hospitable people in America. At every hand I found people, whom I had neither seen nor heard of before, inviting me to dinner, and taking me rides in their cars. Further, $I$ found $I$ was friends with the police, and that without any difficulty either ! In fact, the very air of California is charged with friendliness. Consequently, I was sorry when the day came when I should leave it behind. 
Lizzie was finished. She had had a complete overhaul and several parts of the engine replaced. Numerous telegrams and letters had been flashed across the States to the works at Chicago. They were in vain. Although still under the makers' guarantee, they would accept no responsibility. I paid the last bill that made Lizzie's repair account just exceed the amount $I$ originally paid for her three months before and started out to complete the journey to San Francisco. I cannot, however, omit to mention the extreme courtesy and hospitality with which I was met at the Henderson Agency itself. I could never at any time wish for better attention or hope to make better friends in foreign countries than I was fortunate enough to do in the "City of Angels." I left it with a pang of regret.

It was late in the evening when I started. I found to my annoyance that the lights were defective. The headlight was hors de combat. Only the "dimmer". remained to light me on my way. I had about sixty dollars in my pocket, though, so I was the perfection of happiness withal.

I am afraid those sixty dollars need some explanation. I arrived in Los Angeles a week before with about twenty. The Post Office, as ever, maintained an inexplicable silence. Having now quite reconciled myself to being mailless wherever I went, save for a letter or two forwarded through my friends in Cincinnati, I decided to direct my energies to a profitable purpose while waiting for Lizzie's return from hospital.

I scanned the newspapers night and day. Had I been a tram-driver or a page-boy I could have made a hit at once without any difficulty. There was also a big demand for boot-blacks, but for anything that suited my tastes 
and Inclinations there was nothing. My small stock of "greenbacks" (paper dollars) was slowly diminishing the while. Something had to be done.

So I started in on journalism. Strange to say, I made money at it. With the one exception of Kansas City, it is the only time I ever have. Americans seemed interested in the impressions of stray Englishmen through "God's own country." Better still, Californians seemed interested to learn what one stray Englishman in particular had to say about California on the one hand, and all the other States on the other!

I have the best of reasons for believing that they were perfectly satisfied with my report. So that is how, after paying for Lizzie's operation, I still had sixty odd dollars left to my credit.

The broad, well-lighted city streets with their trolleycars soon were left behind, and we rode for miles along boulevards of wondrous surface through the residential quarters of Los Angeles. There were magnificent bungalows of countless variety, the homes of both poor and rich. Further on, we passed through Hollywood, the home of the homes of the "movie" people. Occasionally would be seen a great block of buildings, unpretentious in architecture but palatial in extent. These were the "studios" where the films are made that instruct, amuse, and annoy the world's population.

Finally, the last bungalow receded into the background and ahead was inky blackness, a beautiful concrete highway, and the faint forms of mountain ranges. In the darkness, dispelled only within a radius of a few feet by the small pea-lamp that remained in service, everything looked mystic, shadowy, and strange. It seemed fust the night, just the surroundings for adventure, the 
kind of environment that makes the vagrant life so much worth living.

The road ran parallel with the coastline, some ten or more miles away, but in between lay the Santa Monica Mountains, whose feet the highway skirted. Sometimes the hill-sides were barren and rocky; other times they were clothed in gloomy cedar forests. I wondered what strange animals lurked in them and whether I should make the acquaintance of any mountain lions, bears, wolves, wild cats and other animals that still are plentiful in the mountain regions of California. Occasionally a car passed, the glare of its headlights transforming the sombre surroundings into a still stranger world of silver and gold. The road for a few moments changed to a path of glistening white leading to the unknown. And then, when the car dashed by, everything plunged instantaneously into a sea of blackness so intense that it could almost be felt.

I had intended to polish off a couple of hundred miles before morning. I love nothing better than a long night ride on a good road. But lack of illumination defied my intentions. After thirty miles I pulled in to the side of the road where a great beech tree overhung its branches, and laid down my ground-sheet upon the soft bed of dead leaves and nuts that lay beneath.

It was the softest mattress that I have ever lain upon in the open. In a few minutes I was fast asleep.

In the early hours of the morning I began to dream. I dreamt that some great animal was walking slowly around me as I lay. It snuffled about, grunting at intervals In a most dissatisfied manner. It is not a habit of mine to dream about anything. I remember reflecting subconsciously that $I$ had ceased to dream of bears and such 
like when I reached the age of four. Why then should I dream about them now ? Oh, hang the fellow! What is he making that confounded noise for ?

A few minutes later I discovered that I was not dreaming at all. I was wide awake. Without moving anything but my eyes I peered into the darkness that still enshrouded everything. Sure enough I could make out a huge black mass somewhere near my feet, but could not discern its actual form. . . . Slowly, gently, I slipped my hand underneath my pillow. At last, I thought, I shall have a chance of shooting at something bigger than prairie-dogs! And then the thought struck me, how strange it was that in all these thousands of miles of travelling through plains and deserts and forests, my slumbers had never been interrupted by any nocturnal visitor-I had not even SEEN anything that could possibly annoy the most domesticated young person who loves his feather-bed.

The big black thing became more distinct as I looked. His head was down and he was engaged in wondering just exactly what my feet were and who put them there; whether they'd be nice to eat if vegetable, and if not, whether they were animal or mineral, and if so, why? I waited my time. He put his head closer to smell the offending object. With a sudden kick I landed out straight for his nose with my right foot. A yell rent the air and the big black thing leapt away squealing into the darkness. A 33 bullet followed him there just for luck.

His squeaks gradually died down as he scampered helter-skelter down the road. It was only a poor harmless pig looking for nuts-but he had no right to disturb my slumbers! 
In the morning we continued towards the west. The end of the Santa Monica Range came in sight and soon the road descended in long winding "grades" towards the sea-coast. For the first time by daylight I saw California in its true colours. Here I should mention that the height of summer is not the best time to explore California. It is in the winter and the spring that the country is arrayed in its greatest glory. The lack of rain, even near the sea-coast, is so marked that by the time summer is reaching its zenith, there is not a green blade of grass to be seen. The face of the country, where it remains uncultivated and unirrigated, is an eternal brown. At first this brings a sense of disappointment to the traveller who has heard so much of California's meadows of wonderful green mingled with the hues of countless kinds of wild flowers. In summer-time there are none. But in spring-time, when the sun has not started to blaze and the rain has worked its miracles, the charm of the country must be beyond description.

At Ventura, a pretty town on the sea-coast, Lizzie's speedometer ticked off the 4,500th mile. There remained another 450 to be done, and the journey would be at an end. I had little doubt now of getting there. The roads were so good that motor-cycling was child's play. Indeed it often became monotonous. At most times one could travel at almost any speed of which one's machine was capable, and still the straight, flat roads would be tiring to the point of boredom.

The towns and villages one passed, however, were full of charm. The most famous road through California, El Camino Real-which means "The Highway of the King "- was one which I was following and had its origin in the old trail which the historic padres followed in the 
romantic days of the Spanish occupation two and three hundred years ago. This trail, blazed by the padres " by God's will for the reigning monarch of Spain," stretches for 900 miles from Mexico to Oregon, and along it there still stand the old Mission Houses that are so prominent a feature of Californian history. There are nineteen of them, each "a day's journey apart," and each of an entirely distinct and characteristic type of architecture.

These Missions stand to-day, having with few exceptions been maintained intact in their original form, and they serve as beautiful testimonies to the genius of their builders. So admired is their style of architecture that they are religiously copied, more so now than ever before, in public buildings and sometimes private dwellings in all parts of the West. One even sees railway stations and tramway termini modelled in the form of one of these ancient Franciscan Missions!

If I was charmed with Ventura, I was thrice charmed with Santa Barbara, another wonderful coast town of modern style built on an ancient site. The old Santa Barbara Mission stands away up on the hill-sides of the Santa Ynez Range above the town and looks over the blue waters of the Pacific towards the craggy islands of Santa Cruz that lie beyond. For sheer delight of climate, scenery, and surroundings I would forsake any home in any town in any country that $I$ have yet seen to live in Santa Barbara, had I the wherewithal to do so.

Following the coast-line, and in many places separated from it only by a ridge of stones or a strip of vegetation, the road continues on its happy way for many miles. On the left splash the deep blue waters of the Pacific. On the right rise steeply the Santa Ynez Mountains, which 
like a link in a great chain form, with many others, more or less disjointed, the "coast range" that fringes the sea from Mexico to Oregon. Sometimes the road is bordered with Yucca palms, sometimes with pepper trees, and sometimes with eucalyptus. One even sees, almost simultaneously, cactus plants and prickly pears growing amid the parched-up grass on the sun-swept side of some unfriendly hill !

At Caviota, a few miles south of the famous "Point Conception," the road leaves the coast and swerves inland. Across the tip of the Santa Ynez Range it goes, swerving now to the left, then to the right, climbing, dipping, and swerving again for sixty or seventy miles until once more it catches a glimpse of the Pacific at El Pismo beach.

Near here I left the beaten track and followed a narrow pathway that led around a hill-side to the cliffs. Here I made my bed down once again in the long, dry grass that clothed the top. I could say with tolerable certainty that never before had a motor-cycle followed that path. It was soon no more than a little rut scarcely visible in the grassy slope. But I achieved my objective. With the murmur of the sea, as it dashed against the rocks a few hundred feet below, singing always in my ears, I passed one more night of exquisite repose and magic charm.

I awoke in the morning and sniffed the sea air. It was very attractive certainly, but was there not something the matter with it somehow ? Or was it my imagination? I wriggled half out of bed and peered over the edge of the cliff. I stopped; I looked; I listened. Down there, on a little bed of white sand, lay a dead seal stretched out flat, as one would lay a tablecloth. He looked a dismal sight, poor fellow. 
Ten miles more, inland again, and it was breakfasttime. We were at San Luis Obispo, a fine little town at the foot of the Santa Margarita-one more link in the coast range. San Luis Obispo took its name from an old Mission founded in 1772, and once was the centre of wealth among the Spaniards of the country.

Afterwards we cross the hills and continue northward. Always the Southern Pacific Railroad is on our right, sometimes just a few feet from the highway. The concrete has stopped and at intervals we have our old friend, the natural gravel. The laying of concrete is being proceeded with at many places, a hundred yards or so at a time, and detours running parallel at the side connect us up with the road ahead. Many little seedling towns are passed-all of them well planned and well advertised -and at last we come to Paso Robles (Pass of the Oaks), a larger town which derives its name from a great natural oak park. I should mention that oak trees are abundant in California and they grow often to a very great size.

We are now in the Salinas Valley, in proportion like a long, narrow groove $\mathbf{1 0 0}$ miles long cut in the face of the country. Through it runs the Salinas River, winding and bending with great sweeps through its sandy bed. At midsummer it is dried up completely, and, from the long wooden bridges that cross and re-cross it, looks like a sandy seabeach, with fences across from one bank to the other to stop the cattle straying!

Along this valley blows a constant cool wind from the sea in the north. All day long it blows, week in, week out. The further north one proceeds the stronger it becomes, until it approaches almost a gale that whistles down the narrow channel like a cold blast, even in the broiling heat of the cloudless sun. Where, here and 
there, were to be seen bunches of poplar trees and eucalyptus, they were invariably leaning distinctly to the south, their gaunt trunks permanently moulded by the inexorable wind. On the smaller trees, the sycamores and the cedars, there was often not a branch nor a leaf to be seen on the northern side of the trunk, the foliage almost touching the ground on the southern side. Those hundred miles were the coldest I had known in the whole journey, and always I found the head wind so strong that the power of the machine seemed half absorbed in merely combating it.

San Miguel, San Ardo, King City, Soledad, Gonzales, and finally, at five in the afternoon, Salinas was reached at the end of the valley. San Francisco was now but little more than 100 miles beyond. To-morrow would be the last day. The end was in sight.

But what of Lizzie? Alas, she was in a sorry condition. Gradually since we left Los Angeles two days before she had fallen off in power. The old rattles and noises had recurred with astonishing alacrity. I had had many stops for minor adjustments and examinations, and even feared another breakdown before the skyscrapers of 'Frisco loomed in sight. The reader may be in as good a position as $I$ to judge of the merits of American compared with English motor-cycles, but he will admit that seldom could occur a worse combination of bad luck and pig-headed pertinacity than is witnessed in the wanderings of Lizzie and me through the United States of America.

At Salinas I ate and drank right heartily, and drowned my sorrows in wistful contemplation of the blue eyes of the gentle damsel who served apple pie across the counter of the "quick-meal" luncheon bar. 
"Lizzie, would you like to sleep by the sea to-night for the last time? Think we can get there, old girl ? It's twenty miles there and twenty back, y' know !-Righto, c'mon!" and she burst once again into an animated confusion of noise and life.

Monterey is on the coast. It stands surrounded by hills on a magnificent bay which, with its yachts, motorlaunches, and fishing-boats, is one of the most famous beauty-spots of the Californian coast. Monterey was once an important centre of history in the early days of Spanish and Mexican sovereignty. Later, it enjoyed the distinction of being the first spot in California where the American flag was hoisted. Now it is little more than a seaside resort, but as famous in California as is Naples in Italy.

A splendid highway leads from Salinas and cuts through beautiful hills clothed in cedar and oak. The journey was worth doing, if only to breathe the sea air again and sleep to its murmur.

It was rather a pathetic affair-that last night out. I hated to leave Lizzie propped up on her stand on the low cliffs while I made a comfortable bed in the sand on the beach. The tide was out, but I was determined to get as near to the sea as possible. I chose a spot where, nestled in a sandy cove in the rocks, I could see the breakers just a score of yards from my feet.

I awoke in the early morning to find the sea barely a foot from my feet. The tide rose higher than I had expected, but I had time to enjoy a few delightful minutes of lying half awake in bed before I finally proved discretion to be better than damp bedclothes and dragged my belongings to a less obtrusive spot.

Thus dawned another day, the day that was to see the 
end. I had ample time and lingered on the way, now administering friendly attention to Lizzie, now stopping for a light refreshment or to take a leisurely photograph. It was all too glorious-that last day.

But poor old Lizzie again showed signs of exhaustion. I nursed her tenderly and rode as slowly as I felt inclined throughout the day.

Monterey was left behind after breakfast. Then Salinas was reached once more, and now we were again on the road to 'Frisco.

Over the mountains to the east once again, down the San Juan Grade, that wound and screwed itself round the rocky slopes, and we got to San Juan, where the tall eucalyptus and waving pepper trees gave an air of majesty to the fine old Mexican town it proved to be.

Then we turn to the north once more and enter another valley, the valley of Santa Clara. The towns become larger and more frequent, the country more developed. Orchards and fruit-groves are frequently seen. At the road-sides, built up on trestles, are great water-tanks that are used for irrigation. I notice that here and there, where the pipes that lead to them have leaked a little, the dark brown soil below has burst into great masses of fresh green grass, while all around is parched and lifeless.

At San José we find a great fruit-growing centre, and at the same time a beautiful city of many thousand inhabitants. Its streets are lined with palms and its suburbs extend into the orange groves that abound on every hand.

Simultaneously one cylinder starts to misfire, and then another. Soon they are all missing. At intervals they would all chip in for a second or two, and as suddenly chip out again. I smelt magneto trouble. 
I also smelt prunes, millions of them. O Californlan Prune, how often have I eaten of thy tasty endocarp in far-off England! And here thou art in myriads about me!

I stopped a dozen times, changed plugs, examined leads, and tinkered with the magneto. Evidently there was something the matter inside the magneto. I would trust to luck to get to 'Frisco-only forty miles more.

And thus we continued, sometimes dawdling along at fifteen and then suddenly bursting into full power and shooting along at forty for a minute or two, as Lizzie's peculiar whim would have it. It was annoying, tiring, disheartening, but I felt I should get there. I had long since planned a trip to the Yosemite National Park, returning thence to the north across the border and eastward through Canada back to New York. That little project would certainly never come off. I had had enough already. I made one great big oath to sell Lizzie's carcase for what it would bring in San Francisco. Poor old Lizzie! I pitied her in a way. She must have been born with a curse on her head. But she would have to go, if only for 100 dollars. Already I began wondering who would get her after we had parted.

After ten miles appeared the southern tip of the great harbour that stretches inland to north and south from San Francisco. This bay is fifty miles long and ten miles wide and forms one of the grandest harbours in the world. All the navies of all the nations of the earth could be comfortably tucked away in a corner of it. The road follows within a few miles of the western shore of this inland sea, and at every few miles are small, fastgrowing cities comparable with nothing but their prototypes that cluster around Los Angeles. For here we are 
absolutely in the centre of the wine-making district. Sixty years ago cuttings and rooted vines of every variety found in Europe were brought to California and planted, mostly around this great bay of San Francisco, where the frequent sea-fogs contribute so much to the maintenance of perfect conditions for the growing of vines. They flourished, and now we have Médocs and Sauternes and Moselles and countless others from California, as well as from France.

For miles and miles we see nothing but vineyards and fruit-groves. There is no fence, no ditch, no railing. The orange trees and plum trees fringe the very road. It is not possible to say where one estate ends and another begins. The owners probably know.

The towns are now so thick that with them also it is difficult to say where one ends and another begins. Only another fifteen miles! Poor old Lizzie, she may peg out altogether.

But no. She keeps at it. Sometimes she ceases firing altogether, but only for a moment. On she goes again, now on one, now on four cylinders. Hey ho! We shall get there all right.

'Buses and cars in hundreds pass in both directions. We shall soon be in 'Frisco now.

Tram-lines appear and then trams. Trolley-cars, they call them in America. 'Frisco at last!

I dodge in and out of the traffic as best I may. It is very thick indeed, and in very much of a hurry. I sail down Market Street, the "Strand" of San Francisco. What matter if Lizzie clatters and rattles and stops and shoots on again? She has brought me here. And as I say so, the little indicator on the speedometer moves to 4,950. Just 50 miles short of 5,000 from New York! 
Gee! it seems like an extract from another life, that departure from far-off New York. And how long? Three months? It feels like twelve at the least!

I found the post office and sang out for mail. Sure enough there was some-forwarded from Cincinnati. I learnt for the first time that the detailed "Schedules" that I had dispatched three months ago at New York had not yet reached England. Hence the reason for the seeming unkindliness of the Post Office en route. But where were they? I was not to know until a week after my return to England, when they arrived suddenly, without any warning, and simultaneously, to all my friends and relatives there. They had been all round British East Africa; Heaven and the New York postal authorities alone know why! I had not counted on such waywardness on their part when in my innocence of American ways I had dropped them in the post-box at New York.

Thus ends my tale of woe. It is a strange thing, but nevertheless true, that now I have done with it and written about it and done with writing about it, I still think what a glorious trip it was and what a perfect ass $I$ was to do it, and what a still greater ass I was to say anything about it ! 


\section{EPILOGUE}

\section{SCENE I}

Scene.-Outside the Post Office, San Francisco, Cal. Time.-August, 1919.

\section{CHARACTERS}

LizziE.

MYSELF.

An Armenian.

Crowd of Loungers, Small Boys, and Women of various Nationalities.

(SelF emerges from portals of Post Office. Chorus of voices from crowd.)

" 'Ere 'e is ; look at his face; look at his chest. You're one globe-trotter, I'll reckon. How long did it take? How much has it cost ? What did you do it for ? How'd you like San Francisco ?" etc., etc., etc.

MYSELF (dangerously rufled at not having received a cheque). "Well, and what are you all gaping at, like a lot of half-witted school-kids? Never seen a motorcycle before? Here, you (to Armenian), where's the Clift Hotel ?"

Armenian. "Do you vont to zell zis machine?"

MYSELF (successfully concealing rapture at the suggestion). "Sell her, after she's brought me all the way from New York? Sell Her? Why, I'd sooner sell my mother-in-law." 
Armenian. " I vill gif you 'undred dollar right 'ere."

Myself. "Hundred dollars be damned, and you with 'em! Where's the Clift ?"

Chorus of Vorces. "Up the hill here and second on the right. Von 'undred dollar. Follow the trams. Give us yer waterbag, boss. Look at his boots. There's a cop on the corner. Von 'undred ten dollar, right now. Look at 'is 'air," etc., etc.

(Exit slowly in procession, SELF leading; Alarums and Excursions.)

\section{SCENE II}

SCENE.-My room at the Clift Hotel.

Half an hour has elapsed.

(SELF discovered, washing face. There is a knock at the door.)

SElF. "Come in."

(Enter Armenian.)

Armenian. "Ah, 'ere you vos. Ze manager tolt me your room. I come right up."

SelF. "Apparently."

Armenian. "I vont to buy your motorsickle; vot you vont for 'im ?"

SELF. "Speak respectfully, please. I want 500 dollars for HER."

Armenian (throwing up his hands in horror). "Ah, zat vos too much, my frent! Dot vos more zan you give for 'im-for 'ER."

SELF. "And how the devil do you know what I gave for her ?"

Armenian. "I haf made enquiries, jhust. I af bin to ze aghency 'ere. Zey say it vos 480 dollars." 
SELF. "Well, any fool knows a machine improves with running (the blush is unnoticed beneath my Indian complexion); and what's more, if a machine can stick it all the way across The United States of America it must be a dem good one. I should have asked 600, but I like your face (cold shivers down spine), so I only want 500."

Armenian. "Ah, zat vos far too much. I vill gif you von 'undred fifteen-no more."

Self. "Nothin' doin', bo. Five hundred. Here's my card; you can call round any time between now and to-morrow midday with the money. If you can't do it by then, you can drop in and see me at Salt Lake City after next Wednesday, or Chicago after next Saturday. Cheerio ; close the door as you go out."

ARMENIaN (reading card and much arved by same). "Ah, you vos Mistaire Sh— Captin Sheffer, R.A.F.? I tink you vos vaire rich man. You could afford to GIF me ze machine! Not so? Me vaire poor man, Captain Sheffer, R.A.F."

SELF. "If you knew as much about the Air Force as I do, you'd know better, my friend. Now, for Heaven's sake, BUZz OFF, and don't worry me." (Exit Armenian with boros, shufles of the feet, and salaams.)

\section{SCENE III}

Scene. -The same. Half an hour later. A knock. SElF. "Come right in."

(Enter Armenian.)

Self. "What, again? Got the 500?"

Armenian. "Grieved to trouble you vonce more, Captin Sheffer, R.A.F., but all ze money I 'af in ze world 
vos von 'undred twenty-five dollar. Me vaire poor man, Capt__"

SELF. "Yes, I've heard you say so. I believe you. Now we're both liars."

Armenian. "Ah no, you insult me, Captin Sheffer, R.A.F. I am poor, but I am 'onorable man. I tell always ze truth. Zat vos all I 'af in all ze vorld."

SELF. "Look here, Mister-I don't know what your name is, but I guess you're a Hebrew of some kind-_"

Armentan. "My name is Mistaire Karachan, and I come from Armenia."

SELF (aside-"I might have guessed it."). "Well, Mr. Karachan, I'll take your word for it. Give me 125 right now and you can take the machine away with you. She's outside on the pavement. But mind, I shall never want to see your face again."

Armenian (moved almost to tears). "Ah, you vos a torough zhentleman, Mistaire Sheffer; all ze Englishmen are zhentlemen. Zer is only von contry in all ze vorld vaire zer are such zhentlemen."

SelF. "Well, you can hand over the wealth right now, here."

Armenian. "Ah, but I 'af not got it wiz me, Mistaire Sheffer. It is too much to carry about in my pocket. But I can gif you fifty dollar and bring ze rest zis afternoon. Zat vos alright? I can take ze machine now, yes no ?"

SELF. "You can take the machine when you've paid me 125 dollars IN CAsH, and not till then. Get me? I shall be in again at two this afternoon. You can meet me in the hall with the money. Good-bye till then."

Armeniar. "Vell, you vill gif me written undertaking not to sell it to anyvon till then, Captin Sheffer, R.A.F. ?" 


\section{SCENE IV}

ScENE.-The same.

\section{TIME.-3 p.m.}

(A knock on the door, followed by ARMenian.)

Armenian. "Mistaire Sheffer, I 'af come to make you a good bargain. You see zis gold votch? It vos giffen me by my fazer and it is solid gold wiz twentyvon jewels. You could sell it anywhere for fifty dollar. Now you 'af bin zhentleman to me, I vill be zhentleman to you. I vill give you ze votch and von 'undred dollar for your motorsickle! Is it not a bargain, Mistaire Sheffer?"

SELF. "Get out!"

\section{SCENE V}

SCENE.-The same.

Time.-An hour later. A knock on the door.

(Enter Armenian.)

Armenian. "Oh, Mistaire Sheffer, I 'af jhust von more offer to-"

SELF. "Look here, Mr. Karachan, I'm getting fed up with you. Better quit before I bang this water-jug on your head. You've wasted all my day as it is."

Armenian. "Ah, you vill not do zat. I know you vill not do zat. You are too much zhentleman. But wait, Mistaire Sheffer. Hear me vot I say. I 'af von great big suggestion to make for you. I make my living viz growing fruit. I 'af small plantation only five mile from 'ere. I vill pay you for your motorsickle viz grapes. I vill gif you five ton of beautiful grapes and send them wherever you like in United States. Or if you not like 
zat, I vill gif you 'undred dollar and von ton of grapes. Is zat not good offer, yes no ?"

SELF (recovering from momentary speechlessness at the thought of swapping Lizzie for five tons of grapes). "Look here, Mr. Karachan, I've had enough of this fooling. I've undertaken to sell you the machine for $\mathbf{1 2 5}$ dollars, and if you don't bring me the money, and all of it, right now, I'll report you to the police. Now there's an end of it. Get out."

(Exit Armenian amid more alarums and excursions.)

\section{SCENE VI}

ScENe.-The same.

Time.-7 p.m. A knock. (Enter Armenian.)

Armenian. "Oh, Captin Sheffer, R.A.F., I 'af got your money 'ere, but I 'af bin to ze police to register ze machine and zey say I 'af stolen it and vould not let me come away. After much trouble we telephone a big frend of mine who know police and zey let me come away. But zey vont your address and ze registration certificate you 'af in New York."

SELF. "But, Good Lord, man, who the devil said you could register it ? It isn't yours yet ! Give me the money."

Armenian (handing me fifty dollars and a cheque for seventyfive). " 'Ere it vos, but you vos not angry, Captin Sheffer, R.A.F ? I vonted only to save time, because I vont to use ze machine to-morrow."

Self. "Yes, but this is no good (showing the cheque). This isn't Cash. How do I know this'll be honoured ? Besides, the banks are closed now and won't be open till Monday, and I'm leaving to-morrow."

Armenian. "Ah, but no, zey vill 'onour ze cheque. 
Mistaire _ is vaire well known in San Francisco. You can speak to 'im on ze telephone if you like and 'e vill tell you ze cheque is all right."

SELF. "No doubt, but all the same I'll see if the hotel manager here will cash it. If he won't, that's good enough for me. Come along, and we'll see him together."

Armenian. "But you vill gif me receipt now, yes no? Ah, but vot is zis? (picking up a small adjustable spanner that lay on the dressing-table). It is part of ze machine! You vould not surely make me pay for a motorsickle vizout no tools? Ah, Captin Sheffer, R.A.F., it is not jhust; I must 'ave everyzing. Are zer any more__" (At this juncture ARMENIAN is successfully extruded through the doorway, still protesting volubly.)

\section{SCENE VII}

ScENE.-In the hall of the Hotel. Manager behind desk.

SELF. "Excuse me, but I have a favour to ask. I have just done a deal with this gentleman, but as all the banks are closed till Monday, I am wondering if you would be good enough to cash this cheque for me as I am leaving for the East to-morrow."

(MANAGER looks closely at me and proceeds to open till; then, looking at ARMenian, pauses for a moment. Ultimately the money is paid over.)

(ARMenian and SELF walk toward door opening on to street.)

Self. "What the blazes! Where's Lizzie? I left her up against the pavement. She's gone!"

Armenian. "Oh, zat vos alright. I move 'er zis afternoon to a garage round ze corner. Jhust zink how terrible it would be if some one stole 'im!"

SELF. "Well, I'll be goldarned!" 


\section{SCENE VIII}

ScENE.-Garage "round the corner." Lizzie stands surrounded by darkness, Armenian, and Self. Sely discovered explaining to ARMENIAN how the wheels go round and why.

Self. "Well, good-bye, Lizzie, old girl. I grieve to let you go into the hands of this being, but it is all for the best. We've had some jolly times together, but the time is come to part. Good-bye, once and for all; goodbye, GOOD-BYE

Armenian. "Ah, Mistaire Sheffer, you 'av forgot ze adjustable spanner !" 



\section{DAY USE \\ RETURN TO DESK FROM WHICH BORROWED

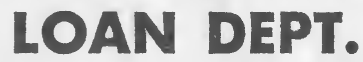

This book is due on the last date stamped below, or on the date to which renewed.

Renewed books are subject to immediate recall.

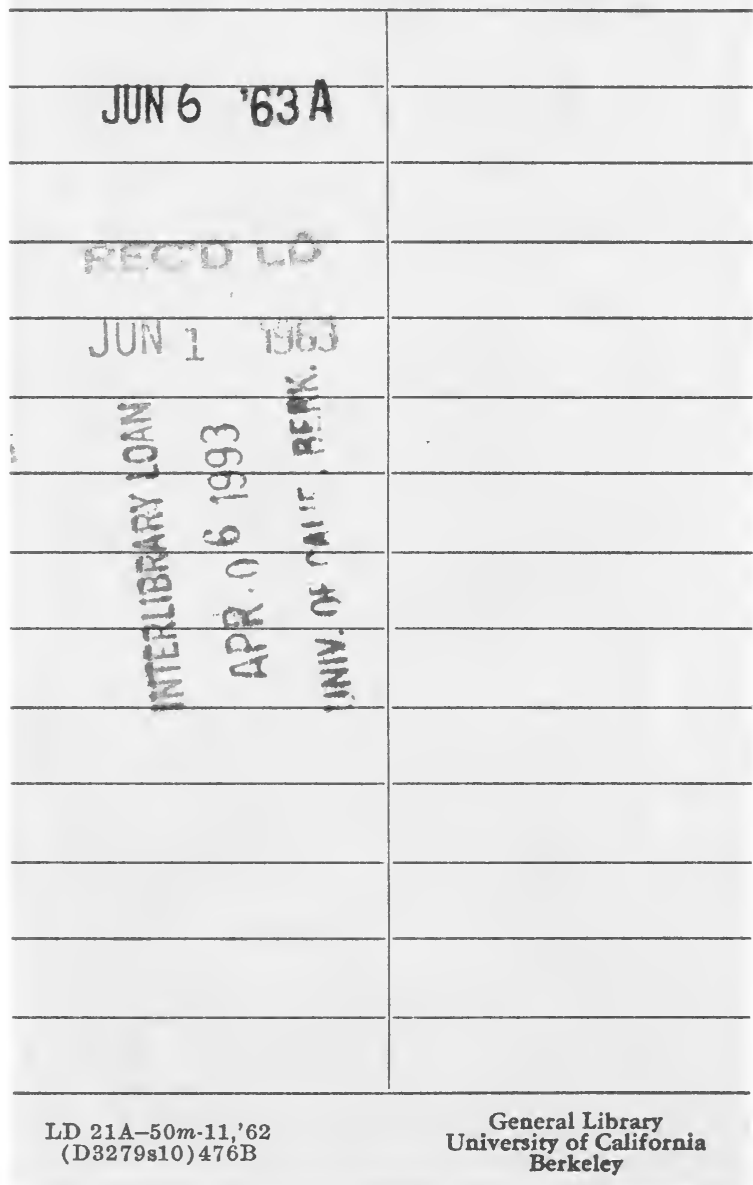



